Review

\title{
An Overview of Cellulose Derivatives-Based Dressings for Wound-Healing Management
}

\author{
Elena-Emilia Tudoroiu ${ }^{1}$, Cristina-Elena Dinu-Pîrvu ${ }^{1, *}$, Mădălina Georgiana Albu Kaya ${ }^{2, *}$ (D) Lăcrămioara Popa ${ }^{1}$ (), \\ Valentina Anuța ${ }^{1}{ }^{\circ}$, Răzvan Mihai Prisada ${ }^{1}$ and Mihaela Violeta Ghica ${ }^{1}$ \\ 1 Department of Physical and Colloidal Chemistry, Faculty of Pharmacy, Carol Davila University of Medicine \\ and Pharmacy Bucharest, 6 Traian Vuia Str., 020956 Bucharest, Romania; \\ elena-emilia.tudoroiu@drd.umfcd.ro (E.-E.T.); lacramioara.popa@umfcd.ro (L.P.); \\ valentina.anuta@umfcd.ro (V.A.); razvan.prisada@umfcd.ro (R.M.P.); mihaela.ghica@umfcd.ro (M.V.G.) \\ 2 Department of Collagen, Division Leather and Footwear Research Institute, National Research and \\ Development Institute for Textile and Leather, 93 Ion Minulescu Str., 031215 Bucharest, Romania \\ * Correspondence: cristina.dinu@umfcd.ro (C.-E.D.-P.); albu_mada@yahoo.com (M.G.A.K.); \\ Tel.: +40-72-230-4894 (C.-E.D.-P.); Tel.: +40-72-339-5108 (M.G.A.K.)
}

Citation: Tudoroiu, E.-E.;

Dinu-Pîrvu, C.-E.; Albu Kaya, M.G.;

Popa, L.; Anuța, V.; Prisada, R.M.;

Ghica, M.V. An Overview of Cellulose Derivatives-Based Dressings for Wound-Healing Management. Pharmaceuticals 2021, 14, 1215. https://doi.org/10.3390/ph14121215

Academic Editor: Federica Sodano

Received: 1 November 2021

Accepted: 18 November 2021

Published: 24 November 2021

Publisher's Note: MDPI stays neutral with regard to jurisdictional claims in published maps and institutional affiliations.

Copyright: (c) 2021 by the authors. Licensee MDPI, Basel, Switzerland. This article is an open access article distributed under the terms and conditions of the Creative Commons Attribution (CC BY) license (https:// creativecommons.org/licenses/by/ $4.0 /)$.

\begin{abstract}
Presently, notwithstanding the progress regarding wound-healing management, the treatment of the majority of skin lesions still represents a serious challenge for biomedical and pharmaceutical industries. Thus, the attention of the researchers has turned to the development of novel materials based on cellulose derivatives. Cellulose derivatives are semi-synthetic biopolymers, which exhibit high solubility in water and represent an advantageous alternative to water-insoluble cellulose. These biopolymers possess excellent properties, such as biocompatibility, biodegradability, sustainability, non-toxicity, non-immunogenicity, thermo-gelling behavior, mechanical strength, abundance, low costs, antibacterial effect, and high hydrophilicity. They have an efficient ability to absorb and retain a large quantity of wound exudates in the interstitial sites of their networks and can maintain optimal local moisture. Cellulose derivatives also represent a proper scaffold to incorporate various bioactive agents with beneficial therapeutic effects on skin tissue restoration. Due to these suitable and versatile characteristics, cellulose derivatives are attractive and captivating materials for wound-healing applications. This review presents an extensive overview of recent research regarding promising cellulose derivatives-based materials for the development of multiple biomedical and pharmaceutical applications, such as wound dressings, drug delivery devices, and tissue engineering.
\end{abstract}

Keywords: cellulose derivatives; wound dressings; wound management; bioactive agents delivery systems

\section{Introduction}

Skin is the largest and the main organ that forms the body covering, with a complex structure of tissues, and creates an exterior defense barrier, which protects the internal organs from mechanical impairments, radiation, chemicals, and foreign invaders (bacteria and viruses) [1]. More than being a passive barrier, the skin defends the body against contamination, infection, and surrounding environment influence [2]. Skin is also a sensory organ and contains a large category of sensory neuron subtypes (thermoreceptors, nociceptors, pruriceptors, and low-threshold mechanoreceptors), that take over and transfer to the brain information about the environment [3]. Moreover, the skin has an important role in homeostasis, elimination of toxins, sustaining regular hydration levels, prevention of electrolytes loss [4], and in control of body temperature and blood pressure. The skin is made up of three particular layers: epidermis, dermis, and hypodermis or subcutaneous layer [5]. 
The epidermis is a physical protective barrier against the external factors, which does not contain blood vessels. It is comprised of two main categories of cells: dendritic cells and keratinocytes (keratin synthesis), along with Langerhans cells (engaged in the immune reaction), Merkel cells (sensory corpuscles), and melanocytes (melanin synthesis) [6,7]. The dermis is situated between the epidermis and hypodermis, and it is responsible for skin thickness. The dermis structure is principally fibrous because it contains collagen and elastic fibers [8]. Moreover, this layer also includes hair follicles, sebaceous glands, sweat glands, nerves, and blood vessels. The fundamental component of the dermis is collagen and the most abundant are type I and type III (approximately 95\%) $[9,10]$. The dermis plays an essential role in thermoregulation, skin protection, preservation of skin support, and perception of sensation [11]. The hypodermis (subcutaneous tissue), the widest and the thickest part of the skin, is located between the dermis and muscles or bones beneath it and it is made up of elastin and loose connective tissue [12]. The principal roles of subcutaneous tissue are thermal insulation, energy resource, nutritional reserve, and mechanical conservation $[13,14]$.

There are many factors and systemic diseases that can alter skin functions, for example, pathogens, pollution, radiation exposure, smoking, malnutrition, obesity, diabetes mellitus, peripheral vascular diseases, pressure ulcer, inflammatory, bleeding, or metabolic conditions and immunosuppression $[15,16]$. In many cases, all these factors can delay wound healing, with harmful risks for patients, such as oxidative stress, chronic inflammation, infection, increased tissue loss, and necrosis [17]. Thus, skin tissue disorders are a public health problem worldwide, with a higher incidence from year to year. For example, in 2005 there were estimated $\sim 5$ million skin and subcutaneous conditions, in $2015 \sim 6.1$ million [18], and in 2018 there were $~ 8.2$ million people, who suffered from wounds. Total costs of treatments for wound healing vary between $\$ 28.1$ billion and $\$ 96.8$ billion [19]. With a prevalence of $1-2 \%$ in the global population, chronic wounds have the largest frequency from all types of skin tissue injuries, especially surgical wounds, and leg/foot ulcers (pressure ulcer and diabetic foot ulcer) [20]. An injury involves physical impact, such as pain, inflammation, mobility limitation, disturbance of sleep, alterations of skin appearance, and restriction of daily activities; consequently, these effects have a negative impact on the patient quality of life, affecting emotional, social, and physical states [21]. To restore the impaired tissue and to rebalance the quality of life for patients with wounds, optimal and multidisciplinary wound management has an essential role. Its main purpose is to obtain a proper functional, structural, and cosmetic result [22]. Frequently, to alleviate the pain and inflammation, which accompany the wounds, analgesic and anti-inflammatory drugs are prescribed. Because of their side effects on the gastrointestinal system when they are administered orally [23], a more advantageous and simple treatment is to apply on the lesion site a wound dressing [24]. The main purpose of wound management is to reduce the period of wound healing through the prevention of infection, alleviation of inflammation and pain, and diminishing the scars [25].

In this review, we mainly present studies from the last 10 years regarding the cellulose derivatives-based wound dressings with various bioactive agents to accelerate the regeneration of skin tissue injuries. Cellulose derivatives have proper and optimal applicability to develop novel wound dressings that can enhance wound healing, obtained by substituting the hydroxyl groups from cellulose molecule with different alkyl groups [26]. Thus, they exhibit high solubility in water and represent a feasible alternative to water-insoluble cellulose. Moreover, these semi-synthetic biopolymers possess other multiple characteristics, such as biocompatibility, biodegradability, proper physicochemical properties, low toxicity and costs, poor immunogenicity, adequate absorption of wound exudates, thermo-gelling power, and antibacterial effect $[27,28]$. Besides wound-dressings development, cellulose derivatives are promising biomaterials for tissue engineering, drug delivery, hemodialysis, osseointegration, and biosensors [29]. 


\section{Wound Classification}

A wound represents a lesion, break, tear, or damage of skin structure and function, produced by physical, mechanical (surgery), thermal, chemical, and electrical (burns) factors; an injury can also be the result of an underlying medical or physiological disorder (diabetes and malignancies) [30-32]. The Wound Healing Society define a wound as a consequence of 'disruption of normal anatomic structure and function' [33]. The National Institutes of Health from the United States assesses that approximately 3\% of people over the age of 65 can suffer at any one time from a cutaneous lesion [34].

Wounds are classified according to many parameters:

- etiology: surgical, traumatic, radiation and malignant wound, chemical or thermal injury, pressure ulcer, diabetic foot ulcer, vascular ulcer, or atypical injury;

- healing time (duration) and nature of the injury restoration process: acute or chronic wounds;

- depth of injury or number of skin layers affected: superficial, partial thickness (deep dermal) or full-thickness wounds;

- complexity: simple, complex, or complicated wounds;

- contamination and postoperative infection risk: clean wound (class I), clean/contaminated wound (class II), contaminated wound (class III) or dirty wound (class IV);

- mode of lesion: abrasion, ulceration, incision, laceration or degloving;

- tissue loss: without tissue loss (surgical wounds) and with tissue loss (burns, traumatic wounds, diabetic foot ulcers, and iatrogenic wounds);

- appearance: necrotic, sloughy, infected, malodorous, granulating, and epithelializing wound;

- injured tissue coloration: black, green, yellow, white, brown, purple, beefy red, or pale pink wounds [35-37].

From all of the classification criteria, the most significant and decisive criterion for selection of an adequate dressing and for optimal wound-healing management is the healing time (duration) and the nature of the injury restoration process. Hence, an acute injury heals totally, without external support, with minimum scarring, and usually demands a period for healing from 8 to 12 weeks [38]. An acute lesion can be simple or complex, but it depends on the affected anatomical parts and on the dimension and depth of this lesion. In this category are found mechanical injuries, burns, and chemical wounds [33,39]. In contrast to the acute wound, a chronic injury heals slowly, requires a long time for healing, more than 12 weeks, usually reoccurs, and leaves severe scars; mostly, a chronic wound does not have any time limitation for the repair process [40]. The main chronic wounds are venous ulcer, ischemic injuries (especially of atherosclerotic origin), diabetic foot ulcer, pressure ulcer, and malignant wounds [41,42].

\section{Wound-Healing Process}

Wound healing is a sophisticated and well-coordinated process [43], which involves a variety of cellular and biochemical reactions that need a complex and dynamic cascade of biological processes $[44,45]$ for the reestablishment of skin layers, growth and tissue regeneration, anatomical continuity, and skin functions [46]. Damaged skin tissue has the capacity to repair itself to form a new epithelium that closes the wound and repairs the barrier function, through an intricate process [47].

\subsection{Wound-Healing Stages}

The wound repair process consists of four different, overlapping, and exactly programmed stages: hemostasis, inflammation, proliferation, and remodeling (maturation) phases [48], illustrated in Figure 1. 


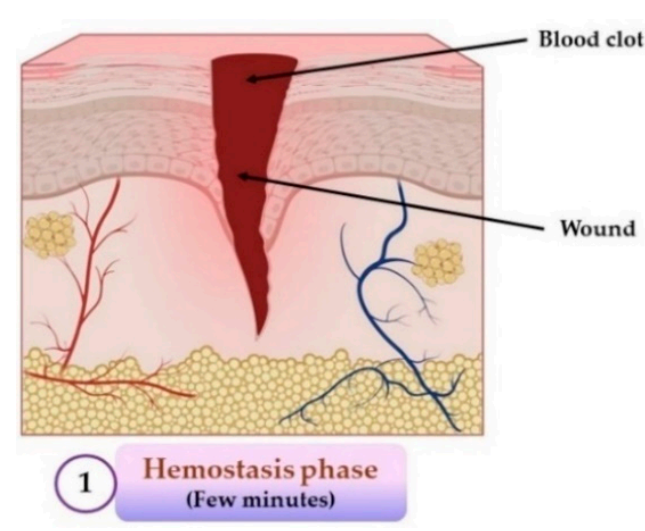

(a)

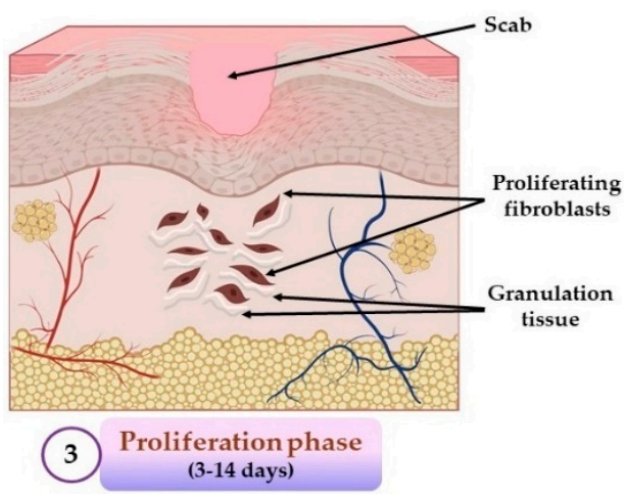

(c)

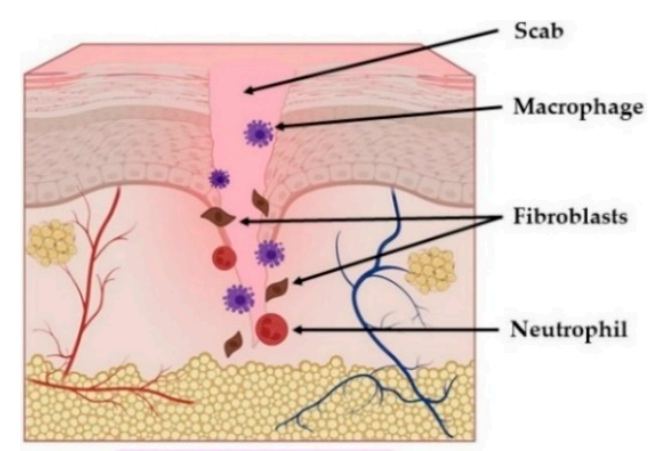
(2) Inflammation phase

(b)

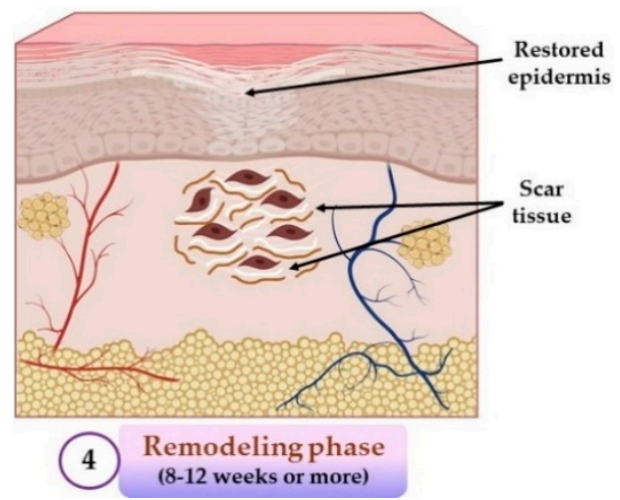

(d)

Figure 1. The four stages of wound healing process: (a) hemostasis phase; (b) inflammation phase; (c) proliferation phase; (d) remodeling phase. All illustrations have been created with BioRender.com, Inkscape, and PowerPoint.

The first and the shortest stage (5-10 $\mathrm{min})$ of the wound repair process is hemostasis, an instantaneous reaction towards lesion [49], whose main purpose is to stop the bleeding through vasoconstriction, primary hemostasis (thrombocytes aggregation with thrombocyte plug formation) and secondary hemostasis (fibrin clot formation) [50]. The inflammation stage happens approximately at the same time as the hemostatic stage and consists of enrollment of neutrophils and macrophages, cytokines secretion, destruction and elimination of bacteria and formation of a wound bed [51]. Inflammation induces accumulation of leukocytes at the lesion's level, activating different mediators and chemotactic factors in 1-2 days after injury and lasts for about 3 days [47]. The proliferation stage begins on day 3 and can have a duration up to 14 days after tissue damage [52]. This phase represents a complex process that includes the next events: neoangiogenesis, production of granulation tissue through fibroblasts proliferation and collagen deposition, synthesis of extracellular matrix, re-epithelialization, and injury retirement, all these happening simultaneously [53]. The final phase of the wound repair process is the remodeling (maturation) stage, and its major purpose is the production of cellular connective tissue and hardening of the new epithelium that establishes the final scar nature [54]. It is the longest stage of all five and can last from weeks to 1-2 years or more. The main event of this phase is the remodeling of granulation tissue, where collagen type I will take the place of collagen type III because type I is more stable [55].

\subsection{Factors Affecting Wound-Healing Process}

Many factors can interfere with the wound-healing phases, the consequence being an improper or damaged wound repair process. In general, these factors can be categorized as local and systemic. Local factors affect features of the lesion itself, and systemic factors represent 
the general health or condition states of one person, which influence the capacity to heal [56]. The main factors that affect the wound-healing process are presented in Figure 2.
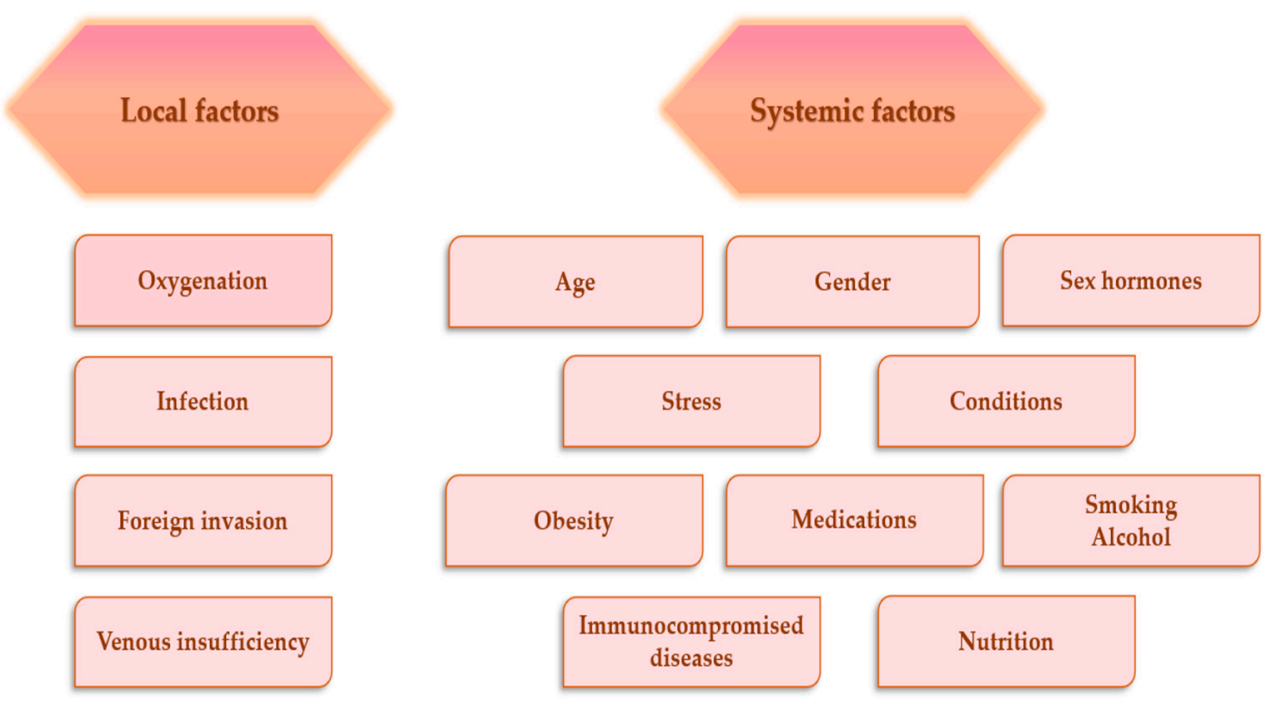

Figure 2. Factors affecting wound-healing process $[57,58]$.

\subsubsection{Local Factors That Affect Wound-Healing Process}

In injured tissues, vascular disruption generates depletion of oxygen, causing hypoxia, and, consequently, impaired wound healing. Temporary hypoxia stimulates the lesion repair process, but persistent hypoxia prolongs this process [59]. Hypoxia is characterized by high levels of reactive oxygen species (ROS) in cells and the impact on tissue healing is deleterious [31,57]. Oxygen has many roles in the injured tissue: avoids infection, activates the angiogenesis, enhances keratinocytes differentiation, movement, and re-epithelialization, increases fibroblast proliferation and biosynthesis of collagen, and stimulates lesion contraction [60]. When skin tissues are injured, the physical protective barrier against foreign invaders is damaged, these germs easily invade the lesion and contaminate or colonize it, causing local infection, and in severe cases, when the injury is not treated properly, they cause systemic infection [61]. Moreover, bacteria and endotoxins may induce the extended elevation of matrix metalloproteinases and pro-inflammatory cytokines (IL-1 and TNF- $\alpha$ ), prolonging the inflammatory phase [56].

\subsubsection{Systemic Factors That Affect Wound-Healing Process}

A main risk factor for the damaged lesion repair process is increased age due to multiple comorbidities [62]. Acute injuries have a prolonged healing time for elderly males compared to elderly females. This fact can be explained through sex hormones, which have an essential role in the wound repair process [63]. Alongside them, stress causes the decrease of pro-inflammatory cytokine levels and the reduction of chemo-attractants expression, which are involved in the inflammation stage of wound healing [64]. Regarding the conditions, the major disease, which strongly and negatively influences the wound-healing process, is diabetes mellitus, because of the diabetic foot ulcer, which causes hypoxia, inhibition of the expansion of macrophages and neutrophils and reduction of fibroblasts proliferation [65]. Obesity represents another major factor that affects the normal repair process, because it is characterized by an augmented workload of the heart to provide oxygenated blood to skin tissues, it cannot perfuse them, the outcome being the onset of ischemia and a higher risk to develop infections [66]. Among medications, steroids and chemotherapeutic drugs can lead to delayed healing. Mechanisms through steroids that affect the wound healing are the inhibition of lesion contraction, and fibroblasts proliferation, the decrease of tensile strength, and collagen production [67]. Chemotherapeutic drugs disturb the proliferative stage through slowing cells' movement to the lesion, angiogenesis 
inhibition, reduction of biosynthesis of collagen and decrease of fibrin deposition [68]. The quality and rate of the normal repair process can be also altered by smoking and alcohol because they lead to lesion infection and dehiscence, reduction of neutrophils, lessening of angiogenesis, inhibition of epithelial reconstruction and lesion contraction, and in severe cases, to necrosis of tissues [69]. Poor nutrition slows the lesion repair process through inflammation extension, inhibition of fibroblasts functions, decline of angiogenesis, and reduction of collagen biosynthesis and deposition [70].

\section{Wound Dressings: Properties and Classification}

In past years, due to the technology's noteworthy progress, various wound dressings were formulated worldwide to cure all types of tissue lesion. Dressings play a fundamental role in wound-healing management because these protect tissue lesions from external invasion (wound dressings are permeable for oxygen and moisture and function as physical barriers) [71], preventing the infection on the wound site [72]. Moreover, dressings contribute to the regeneration and restoration of epidermis and dermis layers [73,74].

\subsection{Wound Dressing Properties}

For the development of dressings, which allow rapid healing, with minimal scars on the body surface, it is necessary to develop new biopolymeric materials that accomplish some properties to create the ideal wound dressing that are reviewed in Figure 3.

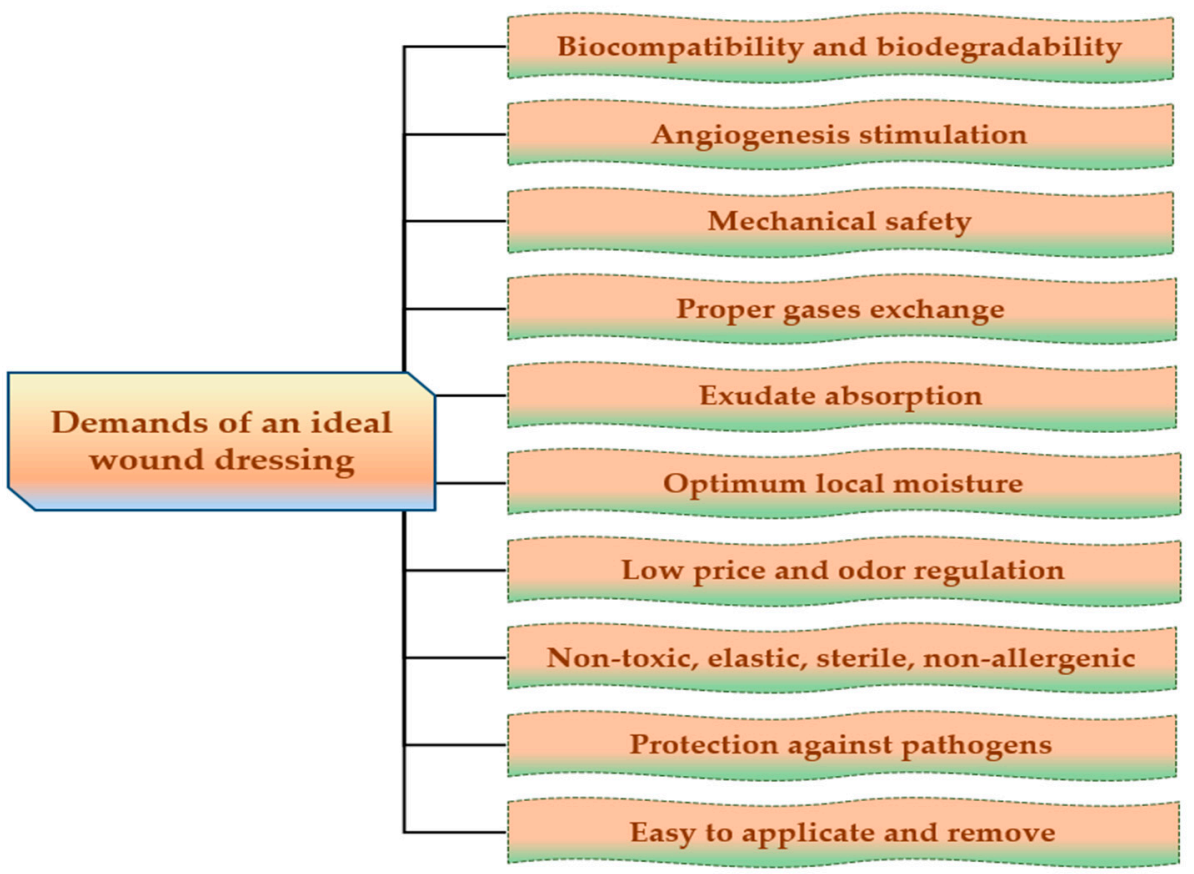

Figure 3. Major demands of an ideal wound dressing.

The ideal wound dressing preferably presents the following features: biocompatibility, biodegradability, non-toxicity, chemical inertness [75], to be applied effortlessly, to have the capacity to keep local moisture, to ensure a suitable exchange of gases $\left(\mathrm{O}_{2}\right.$ and $\left.\mathrm{CO}_{2}\right)$, to absorb exudates that form on the lesion site [76], to stimulate the angiogenesis, to protect against extraneous pathogens, to clear the injured tissue, to eliminate nonviable tissues, to reduce the exposed area [77], to be able to be removed and replaced without difficulty [78], to adjust the odor, to sustain an adequate temperature to the lesion bed, to promote the blood circulation, and to stimulate cell expansion, to ensure mechanical safety [79]. Also, wound dressings materials must be elastic, sterile, non-adherent, non-allergenic [80], to have an acceptable price and to provide thermal insulation [81]. 


\subsection{Wound-Dressing Classification}

A potential classification of wound dressings comprises passive dressings and active dressings, depending on the presence or absence of one or more pharmacologically active substances or natural substances [82], which can act to the site of the lesion, with local or systemic action, conditioned by the depth of the wound. Moreover, the progress of manufacturing led to the evolution of wound dressings from traditional dressings to modern (advanced) dressings [83].

Passive dressings can be considered dry traditional dressings, which are fundamental for a faster wound-healing process. There is a wide simple range of passive dressings for several types of skin lesion: cotton wool, lint, gauze, natural, and synthetic bandages-they work as primary dressing or secondary dressing $[79,84]$. Active dressings contain a large variety of pharmacologically active substances (antibiotics or other antimicrobials, nonsteroidal anti-inflammatory, analgesic, antifungal, and local anesthetics drugs) or natural substances (plant extracts) with anti-inflammatory, astringent, emollient, epithelializing, antioxidant, demulcent, and antimicrobial properties [73].

Modern or advanced dressings were designed to cover tissue lesions and in this category are included the hydrogels, hydrocolloids, semi-permeable films, semi-permeable foams, and alginate dressings [52,85]. The biggest difference between traditional and modern dressings is local moisture maintenance. Thus, traditional dressings have a lower capacity to maintain the local moisture on the wound site [83], and modern dressings sustain excellent local moisture to enhance wound healing [86]. The classification of wound dressings is illustrated in Figure 4.

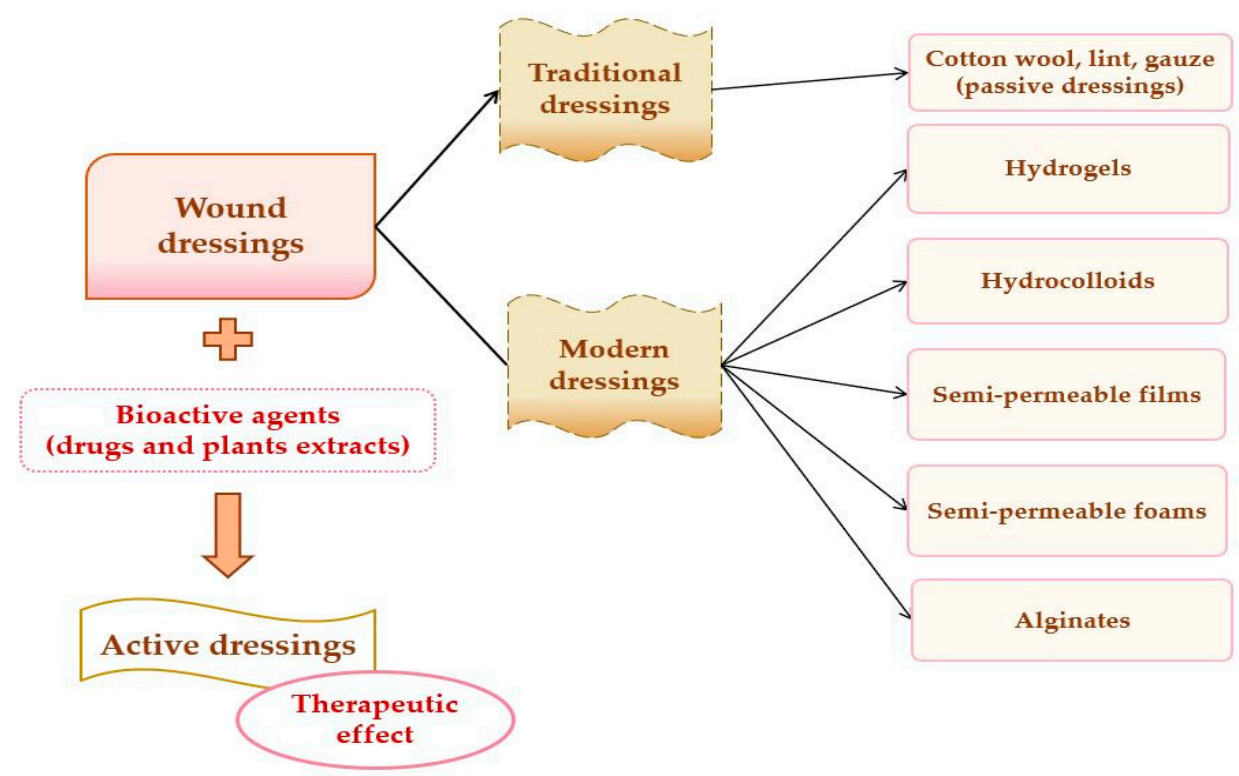

Figure 4. Wound dressings classification.

The main materials underlying the modern wound dressings are polymers, which can be natural (collagen, gelatin, cellulose, hemicellulose, chitin, chitosan, pectins, gums, chondroitin sulfate, alginic acid, alginates, agar, dextran, carrageenan, elastin, hyaluronic acid, silk fibroin, fibrinogen, and fibrin) [87,88], semi-synthetic (cellulose derivatives) [89] or synthetic (poly( $\alpha$-ester)s, polyanhydrides, polycarbonates, poly(amide), poly(esteramide)s, polyphosphazenes, polyurethanes, pseudo poly(amino acids), polyacetals) [90-92].

The first class of modern wound dressings includes hydrogels, also called hungry or smart networks, which can be defined as three-dimensional networks, consisting of cross-linked polymeric materials [93], with a significant capacity to absorb inside their structure a massive volume of water or body fluids, without dissolution in these liquids [94]. Hydrogels are transparent dressings, and this fact allows the tissue lesion to be observed and controlled without the dressing being eliminated [95]. Hydrogels dressings have a 
remarkable application in many domains due to their high water content (up to 96\%) [96], such as biomedical and pharmaceutical sciences (wound dressings, drug delivery systems, diagnostics, tissue engineering, contact lenses, regenerative medicines) [97], agriculture, food industry, biotechnology, separation technology (cells and biomolecules), electroconductive hydrogels and biosensors, oil recovery, the cosmetic industry, and hygienic products [98-100]. Hydrogels, which stimulate autolytic debridement, are used as wound dressings in pressure ulcers, thermal injuries, and lesions caused by surgery [101].

Hydrocolloids are another class of modern wound dressings, which are based on a combination between elastomers, alginates, and colloidal materials. They present the ability to take in a small or medium quantity of exudates, have good biocompatibility, biodegradability, and adhere to the skin [102]. These dressings are occlusive, so they do not allow microorganisms to penetrate tissue lesions, do not afford gases exchanges, and are water-resistant [103].

The third class of modern wound dressing includes semi-permeable films. They are flexible and elastic sheets, made from transparent polyurethane. For a good attachment to the skin, polyurethane films present an acrylic adhesive on one part [104,105]. Films are impermeable to pathogens and water but allow the exchange of oxygen and water vapor. Films are used in surgical injuries or wounds with a reduced volume of exudates [106]. They cannot be applied on tissue lesions with necrosis or infection, on sensitive skin (newborns and elder people), and also on wounds, which have a substantial amount of exudates because films offer a poor capacity to absorb wound fluids $[41,96]$.

The following category of modern dressing includes semi-permeable foams, which showed a vast improvement and favorable biocompatibility [107]. They have a considerable capacity to swallow a great quantity of liquids formed at the injury site, due to their content of hydrophilic polyurethane and silicone, so they can be recommended for tissue lesions with a medium to high status of wound fluids [108]. The disadvantages of foams consist in the limitation of use for dry wounds (foams have a dehydration effect) and in the impossibility to follow the evolution of wound healing because foams are totally opaque [109].

The last class of modern wound dressings is represented by alginates, a category of polysaccharides extracted from brown algae and kelp, with remarkable absorption properties [109]. Alginates are the result of the alginic acid reaction with calcium and sodium; therefore, alginates are called salts $[50,110]$. The formation of alginate gel is based on the exchange of calcium ions, which are inside the dressing, with sodium ions, which are in lesion exudates. Thus, the alginate gel presents an exceptional power to absorb a large volume of wound fluids, especially in the case of foot ulcers [111]. Another advantage of alginates dressings is that they have a hemostatic effect due to calcium ions (known as clotting factor IV, which plays an important role in blood coagulation); accordingly, they can be used if an injury bleeds [112].

\section{Cellulose Derivatives as Wound Dressings}

During the last decades, cellulose derivatives, also known as cellulosics, have become extensively used in many fields, from food, cosmetics, biomedical, and pharmaceutical industry [113] to biofuels and oilfield industry (petrochemicals) [114]. These semisynthetic biopolymers present many advantageous characteristics, such as biocompatibility, biodegradability, non-toxicity, sustainability, abundance, and a suitable price; therefore, cellulose derivatives represent the first option for wound dressings development $[115,116]$.

\subsection{Cellulose Derivatives Classification}

Cellulose, discovered by Anselme Payen in the 19th century, is a natural polymer, an organic polysaccharide from plant origin, non-toxic, with a structural role, being the most plentiful and renewable biopolymer on Earth [117]. Structurally, cellulose is a linear macromolecule composed of many molecules of D-glucose (the number of the glucose units can reach more than ten thousand), which are bound through 1-4- $\beta$-glycosidic linkages 
and its chemical formula is $\left(\mathrm{C}_{6} \mathrm{H}_{10} \mathrm{O}_{5}\right)_{n}$ [118]. The chemical structure of cellulose shows the presence of free hydroxyl groups at $C_{2}, C_{3}$, and $C_{6}$ of each molecule of glucose, which have a good capacity to form powerful inter- and intramolecular hydrogen bonds [119]. As a result of this property, cellulose has a crystalline and stiff structure and, consequently, it is insoluble in water and the majority of the organic solvents; moreover, this natural biopolymer cannot be digested by the human digestive system [120,121]. Cellulose has good stability to $\mathrm{pH}$ fluctuations and temperature [122].

To improve the solubility problems of cellulose and to extend its applications, the chemical structure of this polymer can suffer several changes to obtain the cellulose derivatives, which have suitable physicochemical properties to be used in many fields, especially in the pharmaceutical and biomedical industry [123]. The modifications in the cellulose molecule can be chemical, physical, or biological [114], but the most used and significant of the three is the chemical modification. Targeted by this method are the hydroxyl groups, which suffer an esterification or an etherification reaction [124]. Therefore, the cellulose derivatives can be classified in two major classes: cellulose esters derivatives and cellulose ethers derivatives, which have particular mechanical and physicochemical characteristics [125]. The chemical structures of cellulose and cellulose derivatives are presented in Figure 5.

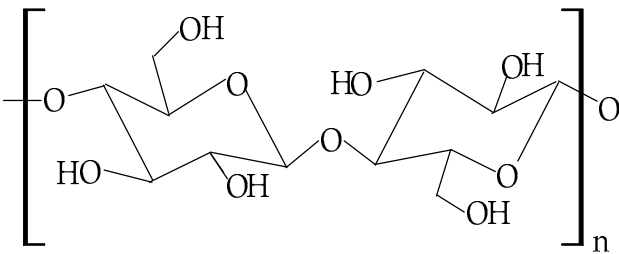

(a)

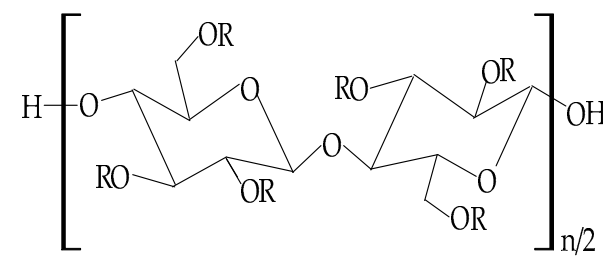

(b)

Figure 5. Chemical structures of: (a) cellulose; (b) cellulose derivatives.

Cellulose ethers derivatives are characterized by high molecular weight and the greatest applicability in the pharmaceutical domain of all these derivatives are: sodium carboxymethylcellulose (NaCMC), hydroxypropylmethylcellulose (HPMC), methylcellulose (MC), hydroxyethylcellulose (HEC), ethylcellulose (EC), hydroxypropylcellulose (HPC), hydroxyethylmethylcellulose (HEMC) and benzylcellulose (BC) $[126,127]$. The cellulose ethers are illustrated in Table 1.

Table 1. Main cellulose ether derivatives according to R groups [128].

\begin{tabular}{cc}
\hline Cellulose Ethers & R Groups \\
\hline Methylcellulose & $\mathrm{H}, \mathrm{CH}_{3}$ \\
Ethylcellulose & $\mathrm{H}, \mathrm{CH}_{2} \mathrm{CH}_{3}$ \\
Benzylcellulose & $\mathrm{H}, \mathrm{C}_{6} \mathrm{H}_{5} \mathrm{CH}_{2}$ \\
Sodium carboxymethylcellulose & $\mathrm{H}, \mathrm{CH}_{2} \mathrm{COONa}$ \\
Hydroxyethylcellulose & $\mathrm{H},\left[\mathrm{CH}_{2} \mathrm{CH}_{2} \mathrm{O}\right]_{n} \mathrm{H}$ \\
Hydroxypropylcellulose & $\mathrm{H},\left[\mathrm{CH}_{2} \mathrm{CH}(\mathrm{CH}) \mathrm{O}\right]_{n} \mathrm{H}$ \\
Hydroxyethylmethylcellulose & $\mathrm{H}, \mathrm{CH}_{3},[\mathrm{CH} 2 \mathrm{CH}]_{n} \mathrm{H}$ \\
Hydroxypropylmethylcellulose & $\mathrm{H}, \mathrm{CH}_{3},\left[\mathrm{CH}_{2} \mathrm{CH}\left(\mathrm{CH}_{3}\right) \mathrm{O}\right]_{n} \mathrm{H}$ \\
\hline
\end{tabular}

Cellulose esters derivatives are extensively used in the pharmaceutical industry as enteric coated drug delivery devices, and they also have excellent properties to form films. There are two categories of cellulose esters: organic and inorganic, but the most common in the pharmaceutical practice are organic esters [129]. Among them are cellulose acetate (CA), cellulose acetate butyrate $(\mathrm{CAB})$, cellulose acetate phthalate $(\mathrm{CAP})$, cellulose acetate trimelitate (CAT), hydroxypropylmethylcellulose phthalate (HPMCP), and hydroxypropylmethylcellulose acetate succinate (HPMCAS). With fewer applications 
in the pharmaceutical industry are inorganic esters, such as cellulose nitrate $(\mathrm{CN})$ and cellulose sulphate (CS) [130]. The cellulose esters are illustrated in Table 2.

Table 2. Main cellulose ester derivatives according to R groups [128].

\begin{tabular}{|c|c|}
\hline Cellulose Esters & R Groups \\
\hline Acetate & $\mathrm{H}, \mathrm{I}$ \\
\hline Acetate trimelliate & H, I, II \\
\hline Acetate phthalate & I, III \\
\hline Hydroxypropylmthylphthalate & $\mathrm{H}, \mathrm{CH}_{3}, \mathrm{CH}_{2} \mathrm{CH}(\mathrm{OH}) \mathrm{CH}_{3}, \mathrm{III}, \mathrm{IV}$ \\
\hline $\begin{array}{l}\text { Hydroxypropylmthylphthalate } \\
\text { acetate succinate }\end{array}$ & $\mathrm{H}, \mathrm{CH}_{3}, \mathrm{CH}_{2} \mathrm{CH}(\mathrm{OH}) \mathrm{CH}_{3}$, III, V \\
\hline
\end{tabular}

Another classification of cellulose derivatives depends on the water solubility of these polymers; thus, there are described in water-soluble cellulose derivatives and waterinsoluble cellulose derivatives. In the first category are included the majority of cellulose ethers (methylcellulose (MC), sodium carboxymethylcellulose (NaCMC), hydroxyethylcellulose (HEC), hydroxypropylcellulose (HPC), hydroxyethylmethylcellulose (HEMC) and hydroxypropylmethylcellulose (HPMC)) [131], while the other cellulose ethers (ethylcellulose and benzylcellulose) and cellulose esters are included in the category of water-insoluble cellulose derivatives. Between the two categories, water-soluble cellulose derivatives are the most used biopolymers in the pharmaceutical and biomedical industry $[115,132]$, because they present several favorable features, such as solubility, surface activity, viscosity in solution, similar properties to thermoplastic film, and proper stability to oxidative and hydrolytic reactions, heat and biodegeneration [130,133].

Due to the general properties of wound dressings presented in Section 4.1, but also the particular properties, such as hydrophilicity, mechanical toughness, $\mathrm{pH}$ stability, and rheological characteristics, cellulose and cellulose derivatives have multiple applications in many fields [134]. Areas of the applicability of all these biopolymers involve: biomedical and pharmaceutical industries, where they can act as drug-delivery devices, wound dressings, muco- and bioadhesive drugs, excipients for drug formulations, and support for tissue engineering [29]; also, they can be used for cosmetic and hygienic products, in the textile area, in the food industry and agriculture [128,135]. The representation of cellulose derivatives-based wound dressing on an open wound is illustrated in Figure 6.

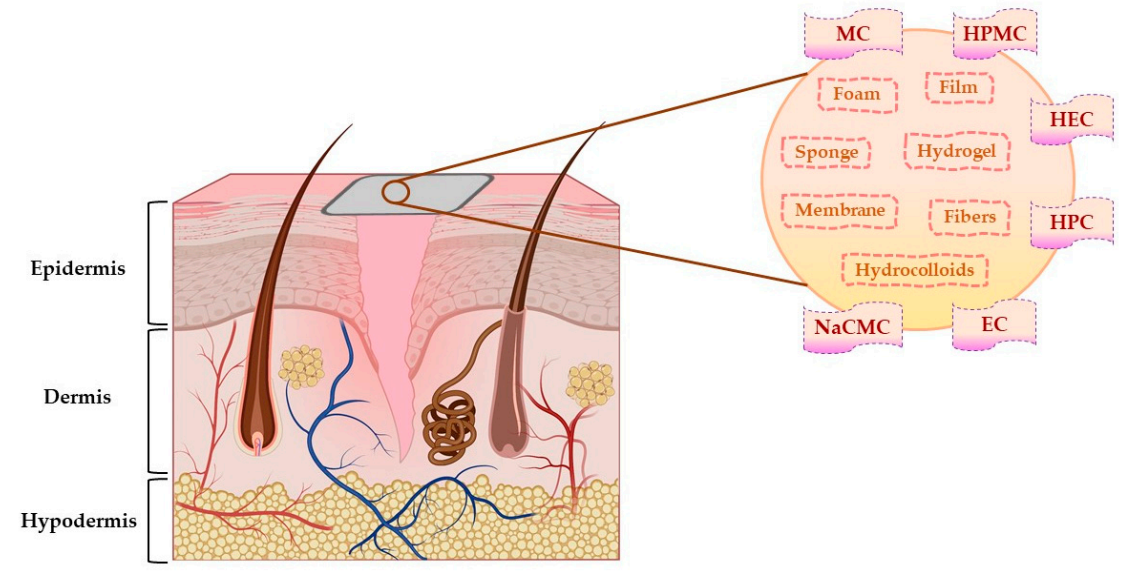

Figure 6. The representation of cellulose derivatives-based wound dressing on an open wound. This illustration has been created with BioRender.com, Inkscape, and PowerPoint.

Cellulose ethers derivatives (Table 1) are the most used biopolymers for tailoring of new wound dressings, compared to cellulose esters derivatives. Therefore, we will further describe them, and we will present their main different types of wound dressings for an optimal wound management, from gels to foams, as we summarized in Section 4.2. 


\subsection{Sodium Carboxymethylcellulose-Based Wound Dressings}

Carboxymethylcellulose (CMC), also known as carmellose, is a semi-synthetic and hydrophilic polymer, a water-soluble cellulose ether derivative, and one of the polymers with the lowest price [136]. Sodium carboxymethylcellulose $(\mathrm{NaCMC})$ is the sodium salt of CMC, an anionic polymer, with a great solubility in water [137]. NaCMC was the first compound from the group of cellulose derivatives; therefore, all the researchers attention was focused on it because, compared to other cellulose derivatives, $\mathrm{NaCMC}$ can be synthesized through simple methods with low-cost materials [138]. It results from the etherification reaction of the cellulose with sodium monochloroacetate in an alkaline solution $(\mathrm{NaOH})$ [139]. In the cellulose molecule, three hydroxyl groups (from 2, 3, and 6 positions) are substituted by carboxymethyl groups [140], resulting in different values of substitution degree from 0.4 to 1.5 and different molecular weights of $\mathrm{NaCMC}$, varying from 90,000 to $2,000,000 \mathrm{~g} / \mathrm{mol}$ [51]. The optimal substitution degree to be used in the pharmaceutical industry is from 0.60 to 1.00 [139]. The chemical structure of $\mathrm{NaCMC}$ is shown in Figure 7.

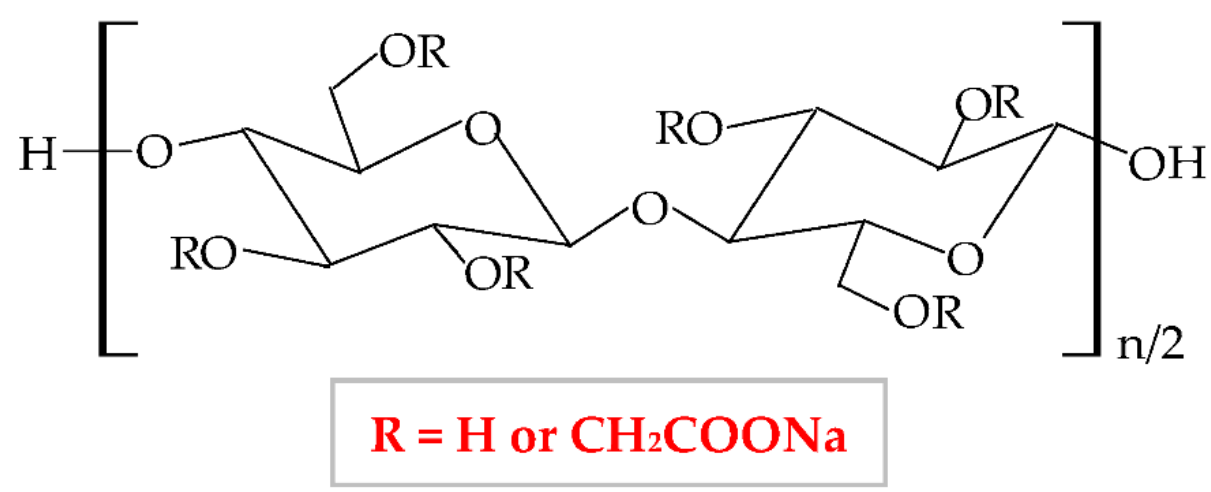

Figure 7. Chemical structure of sodium carboxymethylcellulose (NaCMC).

The $\mathrm{NaCMC}$ network illustrates a thixotropic behavior to generate 3D structures through intermolecular attraction. Its thixotropy is influenced by concentration and degree of substitution [141]. NaCMC presents excellent physicochemical and mechanical properties [142], optimal biocompatibility and biodegradability, proper capacity to absorb the water and to swell, high gelation behavior, non-toxicity, and low-immunogenicity [143]. It is the most used cellulose derivative in the pharmaceutical industry, mainly for the development of new wound dressings because it has the capacity to absorb heavy exudates [144,145], to ensure excellent moisture at the lesion site, and to avoid skin tissues water loss and tissues necrosis. Moreover, an optimal local humidity can impede dehydration, facilitate the synergy between target cells and growth factors, promote angiogenesis advancement, the mitigation of the ache, and the disruption of the fibrin network [146]. $\mathrm{NaCMC}$ is also used as a drug-delivery device and excipient for drug formulations (used as an emulsifier, thickener, stabilizer, and film-maker) [147]. Besides its applicability in the pharmaceutical area, this biopolymer possesses different usefulness in the food (E466 food additive) industry [148], in paper, textile and cosmetics domains [51,149], for tissue culture and dental medicine field [150].

$\mathrm{NaCMC}$ can be combined with other polymers to enhance its properties and to develop its applicability. Thus, it is more advantageous to blend two or more polymers for the development of a new material comparative to the chemical industrial development of that material. Moreover, the new material obtained by mixing other well-known polymers presents all the properties or is more favorable than the component polymers [75]. Furthermore, the blend of polymers can be realized to compensate for their drawbacks. Hence, Liu et al., combined $\mathrm{NaCMC}$ with HEC by electrostatic complexing and obtained a sponge and a membrane with a porous network, enhanced viscoelastic properties, and high swelling behavior [151]. Hu et al., mixed NaCMC with PVA and quaternized chitosan and designed 
a new composite with enhanced flexibility, water absorption rate, mechanical strength, swelling ratio, and humidity permeability [152]. A novel NaCMC/PVA-based composite was formulated, with higher properties than two polymers: improved swelling capacity, elasticity, water solubility, porosity, water vapor transmission rate, bioavailability, and biodegradability for the tissue repair process; this formulation also presented an extension of its applicability, such as agriculture, biomedical field as drug delivery systems and food packaging $[153,154]$. NaCMC was blended with PEG through a photo-click reaction based on thiol-norbornene. It formed a pH-sensitive hydrogel with an augmented swelling ratio [150]. Zhang et al., designed a novel hydrogel based on $\mathrm{NaCMC}$ and sodium alginate. In a ratio of 1:4, the hydrogel exhibited high biocompatibility, mechanical characteristics, degradation rate, and local humidity [155]. Shin et al., blended NaCMC with PVA and PEG 400 through cyclic freezing/thawing method and obtained a hydrogel with improved properties: the swelling rate, the compressive strength, and cytocompatibility [156]. NaCMC can also be blended with diverse biopolymers to develop a new potential wound dressing with better properties to accelerate the wound healing process. All these combinations are illustrated in Table 3. 
Table 3. Recent studies on the use of sodium carboxymethylcellulose as a wound dressing.

\begin{tabular}{|c|c|c|c|c|}
\hline Biopolymer/-s & $\begin{array}{l}\text { Active Pharmaceutical Ingredient } \\
\text { (Natural or Synthetic Substances) }\end{array}$ & Type of Wound Dressing & Main Findings & References \\
\hline \multirow{12}{*}{$\mathrm{NaCMC}$} & \multirow{4}{*}{$\mathrm{C}$} & Gel & $\begin{array}{l}\text { Anticoagulant activity at second-degree burn injuries; this } \\
\text { action was influenced by concentration, substitution degree, } \\
\text { and molecular weight of the biopolymer. }\end{array}$ & [157] \\
\hline & & Hydrocolloid & $\begin{array}{l}\text { Appropriate management of humidity, maintained } \\
\text { self-adhesiveness, and increase of the surface energy. }\end{array}$ & [85] \\
\hline & & Film & $\begin{array}{l}\text { Enhanced tensile strength, absorption capacity, and decreased } \\
\text { percent erosion. }\end{array}$ & [147] \\
\hline & & Foam & $\begin{array}{l}\text { Suitable material for wound dressing, because it can maintain } \\
\text { optimal local moisture. }\end{array}$ & [158] \\
\hline & Merremia mammosa & Gel & $\begin{array}{l}\text { Good gel properties, non-toxicity, speeding the wound } \\
\text { healing process in diabetic ulcer (increases collagen synthesis } \\
\text { and improves angiogenesis). }\end{array}$ & [159] \\
\hline & Chestnut honey & Hydrogel & $\begin{array}{l}\text { Enhanced moisture retention, non-adherence, and excellent } \\
\text { antibacterial action to treat diabetic ulcer injuries. }\end{array}$ & [160] \\
\hline & Reduced graphene oxide & Hydrogel & The inhibition of bacteria biofilm from infected wounds. & [161] \\
\hline & $\begin{array}{l}\text { Neomycin trisulphate, sulphacetamide } \\
\text { sodium, and silver nitrate }\end{array}$ & Hydrogel & $\begin{array}{l}\text { Proper elasticity, sponginess, homogenous texture, suitable } \\
\text { smell, high drugs delivery, and antimicrobial effect. }\end{array}$ & [162] \\
\hline & Tetracycline-UiO-66 & Hydrogel & $\begin{array}{l}\text { Increased mechanical properties, antibiotic delivery, and good } \\
\text { antibacterial activity. }\end{array}$ & [163] \\
\hline & $\mathrm{ZnO}-\mathrm{MCM}-41$ and tetracycline & Hydrogel & $\begin{array}{l}\text { Improved tensile strength, permeability for gases, and } \\
\text { swelling ratio; optimal antibacterial effect. }\end{array}$ & [164] \\
\hline & Lidocaine hydrochloride & Film & $\begin{array}{l}\text { Optimal physicochemical and mechanical properties; high } \\
\text { drug release (90\%) in the first } 15 \mathrm{~min} .\end{array}$ & [165] \\
\hline & AgNPs & Membrane & Good morphology and superior antibacterial activity. & [166] \\
\hline $\mathrm{NaCMC} /$ Chitosan & - & Sponge & $\begin{array}{l}\text { High porosity, air permeability, and proper antibacterial } \\
\text { effect; in the presence of the cyanine dye, the sponge } \\
\text { indicated the } \mathrm{pH} \text { of the wound site. }\end{array}$ & [167] \\
\hline $\mathrm{NaCMC} /$ Pullulan & - & Hydrogel & $\begin{array}{l}\text { An important decrease of the hydrogel adherence at the } \\
\text { postoperative lesions. }\end{array}$ & [168] \\
\hline \multirow{2}{*}{$\mathrm{NaCMC} /$ Sericin } & \multirow{2}{*}{ - } & Hydrogel & $\begin{array}{l}\text { Increased mechanical stability and the strength to hydrolysis } \\
\text { and enzymatic degeneration; the molecular weight of CMC } \\
\text { influenced the sericin release. }\end{array}$ & [169] \\
\hline & & Film & $\begin{array}{l}\text { Higher mechanical properties, hydrophilicity, swelling power, } \\
\text { stability, compatibility with cells and blood, and stimulation } \\
\text { of cell proliferation. }\end{array}$ & [170] \\
\hline $\mathrm{NaCMC} / \varepsilon$-Polylysine & - & Hydrogel & $\begin{array}{l}\text { Optimal rheological properties, degradability, compression } \\
\text { modulus, and high antibacterial activity. }\end{array}$ & [171] \\
\hline
\end{tabular}


Table 3. Cont.

\begin{tabular}{|c|c|c|c|c|}
\hline Biopolymer/-s & $\begin{array}{l}\text { Active Pharmaceutical Ingredient } \\
\text { (Natural or Synthetic Substances) }\end{array}$ & Type of Wound Dressing & Main Findings & References \\
\hline NaCMC/Pectin/Cellulose & ( & Film & $\begin{array}{l}\text { NaCMC and cellulose enhanced the mechanical properties of } \\
\text { pectin; the new composite accelerated the tissue repair } \\
\text { through re-epithelialization and collagen deposition. }\end{array}$ & [172] \\
\hline $\mathrm{NaCMC} /$ Chitosan/Sodium alginate & - & Hydrogel & $\begin{array}{l}\text { Optimal water vapor permeability, anti-adhesion capacity to } \\
\text { treat second-degree burn injuries; reduced the TNF- } \alpha \text { and } \\
\text { IL-6 levels. }\end{array}$ & [174] \\
\hline NaCMC/Gelatin/PEG & - & Hydrogel & $\begin{array}{c}\text { CMC increased the mechanical properties, enzymatic stability, } \\
\text { and sanguineous compatibility; the new hydrogel had 3D and } \\
\text { porous structure, absorbed the exudates, and maintained } \\
\text { proper moisture. }\end{array}$ & [175] \\
\hline $\mathrm{NaCMC} / \mathrm{PEG}$ & - & Hydrogel/Film & $\begin{array}{l}\text { Superabsorbent hydrogel with various swelling degrees from } \\
100 \% \text { to } 5000 \% \text {, appropriate physicochemical and } \\
\text { morphological properties to regenerate chronic wounds. }\end{array}$ & [45] \\
\hline $\mathrm{NaCMC} / \mathrm{PE} / \mathrm{PP}$ & - & Fibers & $\begin{array}{l}\text { A serious increase of wet strength; future perspective as a } \\
\text { material for the treatment of wounds with mild exudate. }\end{array}$ & [176] \\
\hline \multirow{2}{*}{ NaCMC/Collagen } & Mefenamic acid & Hydrogel & $\begin{array}{l}\text { Good ability to swell, optimal morphological structure and } \\
\text { excellent release model to treat burns. }\end{array}$ & [177] \\
\hline & AgNPs & Membrane & $\begin{array}{l}\text { Suitable antimicrobial action against pathogens from infected } \\
\text { burn wounds. }\end{array}$ & [178] \\
\hline $\mathrm{NaCMC} /$ Gelatin & Ciprofloxacin & Film & $\begin{array}{l}\text { In a ratio of } 1: 1 \text { and } 1: 2 \text {, the film showed good thickness, } \\
\text { sorption capacity, blending endurance, and proper } \\
\text { antibacterial effect. }\end{array}$ & [16] \\
\hline $\mathrm{NaCMC} /$ Keratin & Clindamycin & Sponge & $\begin{array}{l}\text { The keratin enhanced the water stability and the water vapor } \\
\text { transmission rate; the sponge impeded the bacterial } \\
\text { multiplication. }\end{array}$ & [2] \\
\hline \multirow{3}{*}{$\mathrm{NaCMC} / \mathrm{PEO}$} & $\begin{array}{l}\text { Achillea millefolium, Calendula officinalis, } \\
\text { Matricaria chamomilla, Echinacea purpurea } \\
\text { and Hypericum perforatum }\end{array}$ & Fibers & $\begin{array}{l}\text { Antibacterial and antioxidant activity for acute injuries } \\
\text { treatment. }\end{array}$ & [179] \\
\hline & Lidocaine & Nanofibers & $\begin{array}{l}\text { Similar characteristics as extracellular matrix; } \sim 50 \% \text { of } \\
\text { lidocaine has been delivered in the first } 10 \text { min, relieving the } \\
\text { pain quickly. }\end{array}$ & [180] \\
\hline & AgNPs & Nanofibers & $\begin{array}{l}\text { Smooth surface and limited size distribution; excellent } \\
\text { antimicrobial effect and photoluminescent act, used as } \\
\text { anti-adhesion composite and wound dressing. }\end{array}$ & [181] \\
\hline
\end{tabular}


Table 3. Cont

\begin{tabular}{|c|c|c|c|c|}
\hline Biopolymer/-s & $\begin{array}{l}\text { Active Pharmaceutical Ingredient } \\
\text { (Natural or Synthetic Substances) }\end{array}$ & Type of Wound Dressing & Main Findings & References \\
\hline \multirow{2}{*}{$\mathrm{NaCMC} / \mathrm{PVA}$} & Propolis & Hydrogel & $\begin{array}{l}\text { High swelling power and antimicrobial effect for } \\
\text { second-degree burn injuries treatment. }\end{array}$ & [182] \\
\hline & $\mathrm{ZnO}$ and heparin & Hydrogel & $\begin{array}{l}\text { Favorable mechanical properties, water vapor transmission } \\
\text { rate, swelling ratio, and excellent antibacterial effect. }\end{array}$ & [183] \\
\hline $\mathrm{NaCMC} /$ Soluplus $^{\circledR}$ & $18 \beta$-glycyrrhetinic acid (licorice) & Hydrogel & $\begin{array}{l}\text { Soluplus }{ }^{\circledR} \text { augmented the solubility in water of the bioactive } \\
\text { agent; at the lesion site, and in situ hydrogel formed, which had } \\
\text { high swelling power and was easy to eliminate by washing. }\end{array}$ & [184] \\
\hline $\mathrm{NaCMC/Sodium} \mathrm{alginate/PET/Viscose}$ & Diclofenac sodium & Membrane & Optimal drug release and efficient anti-inflammatory activity. & [185] \\
\hline $\mathrm{NaCMC} /$ Sodium alginate & Diclofenac & Film & $\begin{array}{l}\text { Homogeneous film with proper water vapor transmission } \\
\text { rate; faster alleviation of pain. }\end{array}$ & [186] \\
\hline
\end{tabular}

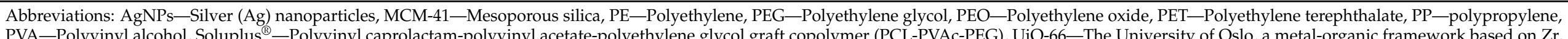
$\mathrm{ZnO}-$ Zinc oxide. 


\subsection{Hydroxypropylmethylcellulose-Based Wound Dressings}

Hydroxypropylmethylcellulose (HPMC), hypromellose [187], is a semi-synthetic hydrophilic polymer, a nonionic cellulose ether derivative [188], with higher stability at a lower $\mathrm{pH}$. In terms of physical properties, HPMC is a white, fibrous, or granular powder, whose particles are not cohesive, and it does not have a taste and odor [189]. This biopolymer results from hydroxyl groups substitution from cellulose molecule with methyl and hydroxypropyl groups. The chemical structure of HPMC is illustrated in Figure 8.

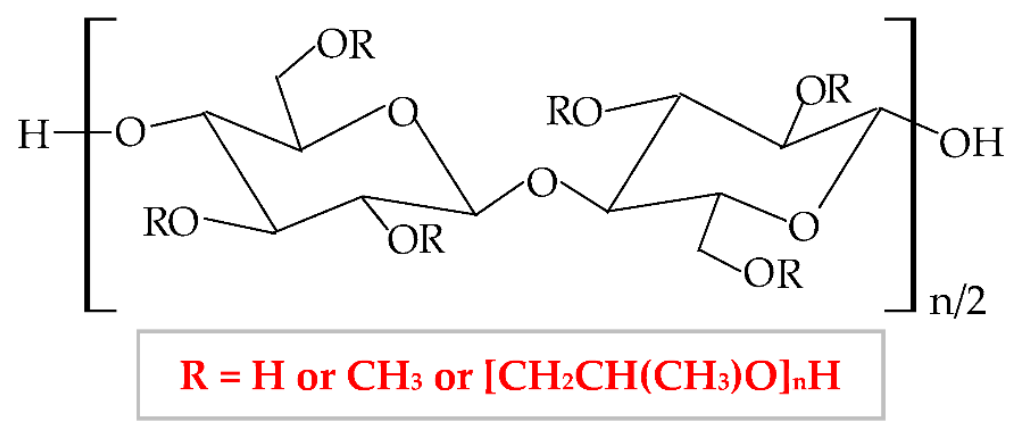

Figure 8. Chemical structure of hydroxypropylmethylcellulose (HPMC).

Therefore, HPMC presents many degrees of substitution, that give to this biopolymer different molecular weight and physicochemical features (rheological properties and crystalline nature) $[190,191]$. The hydrophilic or hydrophobic nature is related to the values of the degree of substitution (DS) and the molar substitution (MS). Thus, the HPMC molecule with decreased values of DS and MS is more hydrophilic and the HPMC molecule with increased values of DS and MS is more hydrophobic [192]. Following this chemical substitution, HPMC gets both polar (hydroxypropyl) and non-polar (methyl) character; consequently, it can form hydrophobic, intermolecular, and intramolecular linkages with many other materials [190]. The non-ionic character leads to a limited adhesive capacity [193]. At high temperature, the biopolymer can suffer a thermoreversible phase transition from sol to gel, with a temperature of gelation over $60^{\circ} \mathrm{C}$, superior to the temperature of the body $\left(37^{\circ} \mathrm{C}\right)$ [194]. HPMC-based hydrogels are temperature-responsive [195].

According to United States Pharmacopeia (USP), there are four distinct forms of HPMC, which are categorized by the content of methoxy, respectively hydroxypropoxy groups in: HPMC 1828, HPMC 2208, HPMC 2906, and HPMC 2910 [196]. This biopolymer has been approved as a food additive, E464 [197], by the American Institute, Food and Drug Administration (FDA), by the European Institution, European Parliament, and Council Directive, and by the Joint Expert Committee on Food Additives [198].

HPMC has a proper solubility in water, and it is one of the most used cellulose derivatives in many industries. It is widely used in the biotechnological field (construction, food, cosmetics, biomedical, and pharmaceutical industry), due to its excellent characteristics, such as biocompatibility, biodegradability, superior stability, large availability, excellent swelling, high surface activity, and mechanical properties [199], remarkable ability to form films and poor toxicity [200]. Regarding the applicability of HPMC in biomedical and pharmaceutical domains, it is used as a drug-delivery device, with a large practice for wound dressings development and it can also have remarkable applicability in tissue engineering [201]. HPMC can also be used as an excipient because it possesses proper abilities of emulsification, stabilization, suspension, and thickening [202,203].

HPMC can be combined with other polymers to enhance its properties and to develop its applicability [204]. To improve the physicochemical properties of a new composite, HPMC has been blended with several natural, semi-synthetic, or synthetic polymers [205]. In this way, to improve the thermal stability, HPMC has been blended with collagen [206,207], gelatin [204], chitosan [208], chitosan, and xanthan gum [209]; to improve the mechanical properties (tensile strength and ultimate elongation), HPMC has 
been mixed with chitosan [210], collagen [207], poloxamer 407 [211], silk fibroin [212], PVA and PVP [213], chitosan and xanthan gum [209]; to increase the swelling rate, HPMC has been combined with methylcellulose [214], k-carrageenan [215], chitosan and hyaluronic acid [216], chitosan and xanthan gum [209]. HPMC can also be blended with diverse biopolymers and multiple bioactive agents (plants extracts, organic or inorganic substances, and chemical drugs) to develop new potential wound dressing to accelerate the woundhealing process. All these studies are summarized in Table 4. 
Table 4. Recent studies on the use of hydroxypropylmethylcellulose as a wound dressing.

\begin{tabular}{|c|c|c|c|c|}
\hline Biopolymer/-s & $\begin{array}{l}\text { Active Pharmaceutical Ingredient } \\
\text { (Natural or Synthetic Substances) }\end{array}$ & Type of Wound Dressing & Main Findings & References \\
\hline \multirow{9}{*}{ HPMC } & $\begin{array}{l}\text { Lawsonia inermis (henna) and } \\
\text { Matricaria chamomilla }\end{array}$ & Gel & $\begin{array}{l}\text { Adequate stability, extrudability, viscosity, homogeneity, good herbal } \\
\text { extract release, and antibacterial effect for burn infection cure. }\end{array}$ & [217] \\
\hline & Liposomal farnesol & Gel & $\begin{array}{l}\text { The combination of HPMC:farnesol in a ratio of 1:2 and 2:1 had an } \\
\text { excellent effect on tissue regeneration at third-degree burns. }\end{array}$ & [218] \\
\hline & Bacteriophage & Gel & $\begin{array}{l}\text { The gel containing } 3 \% \text { HPMC presented good stability at } 37^{\circ} \mathrm{C} \\
\text { and had an effective antibacterial action against } \\
\text { Klebsiella pneumoniae in wound infection treatment. }\end{array}$ & [219] \\
\hline & CuNPs-licorice and phenytoin & Gel & $\begin{array}{l}\text { Effect on acute lesions by the suppression of the inflammatory } \\
\text { JAK3 and the synthesis of the procollagen type I. }\end{array}$ & [220] \\
\hline & Honey and Aloe vera & Hydrogel & $\begin{array}{l}\text { At } 3 \% \text { concentration, the hydrogel presented an adequate } \\
\text { viscosity to be applied on the burn lesions and showed a proper } \\
\text { antibacterial activity on infection with Klebsiella pneumoniae. }\end{array}$ & [197] \\
\hline & Cefotaxime sodium & Hydrogel & $\begin{array}{l}\text { The hydrogel containing 3\% HPMC } 400 \text { exhibited a high } \\
\text { spreadability and released all the drug content after } 4 \mathrm{~h} .\end{array}$ & [221] \\
\hline & Haruan/fusidic acid & Film & $\begin{array}{l}\text { Films with } 1 \% \text { plasticizers, respectively } 2 \% \text { plasticizers presented } \\
\text { a suitable elongation at break and water vapor permeability. }\end{array}$ & [222] \\
\hline & Epigallocatechin-3-gallate & Film & Enhanced tensile strength and water vapor barrier trait. & [223] \\
\hline & Cooper nanoparticles & Film & Appropriate antibacterial activity. & [190] \\
\hline HPMC/Collagen/Polyurethane & - & Hydrogel & Increased proteolytic and thermal degradation. & [224] \\
\hline $\begin{array}{l}\text { HPMC/Polyacrylate/Tri-isocyanate } \\
\text { crosslinked polyurethane }\end{array}$ & - & Hydrocolloid & $\begin{array}{c}\text { The newly designed wound dressing containing } 1 \% \text { cross-linking } \\
\text { promoter showed proper humidity (the capacity of the water } \\
\text { uptake was } 5.1 \% \text { after } 1 \mathrm{~h} \text { ). }\end{array}$ & [199] \\
\hline HPMC succinate/Chitosan & Gentamycin sulfate & Film & High mechanical properties and antibacterial activity. & [225] \\
\hline \multirow{4}{*}{ HPMC/Chitosan } & Simvastatin & Gel & High viscosity and bioadhesive strength. & [17] \\
\hline & Toluidine blue $\mathrm{O}$ & Hydrogel & $\begin{array}{l}\text { High viscosity, hardness, bioadhesion, and bactericidal effect to } \\
\text { alleviate the burn wounds caused by light irradiation. }\end{array}$ & [226] \\
\hline & Pioglitazone hydrochloride & Hydrogel & $\begin{array}{l}\text { The formulation containing HPMC E5:chitosan (1:2) showed the } \\
\text { best physicochemical properties and the highest drug release. }\end{array}$ & [193] \\
\hline & Silver sulphadiazine & Film & $\begin{array}{l}\text { In a ratio of 1:1, the film showed the best physicochemical } \\
\text { properties and the highest drug release; the period of wound } \\
\text { healing was of } 8 \text { days in comparison with the marketed cream } \\
\text { (14 days). }\end{array}$ & [227] \\
\hline
\end{tabular}


Table 4. Cont.

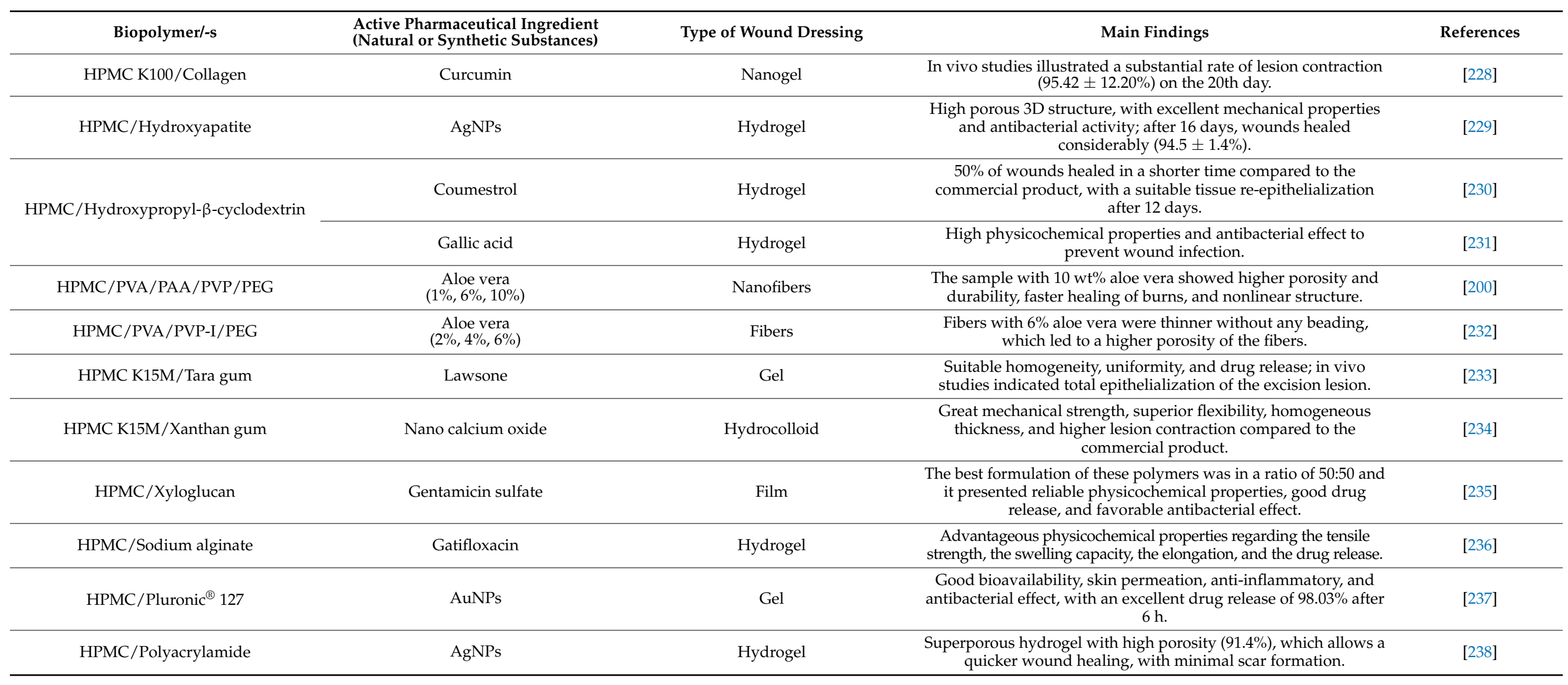


Table 4. Cont.

\begin{tabular}{|c|c|c|c|c|}
\hline Biopolymer/-s & $\begin{array}{l}\text { Active Pharmaceutical Ingredient } \\
\text { (Natural or Synthetic Substances) }\end{array}$ & Type of Wound Dressing & Main Findings & References \\
\hline HPMC/PEO & Beta-glucan & Nanofibers & At the lesion site, the nanofibers produced a hydrogel in situ. & [239] \\
\hline HPMC/Poly(lactic acid) & Tetracycline hydrochloride & Nanofibers & High water sorption rate and antimicrobial activity. & [240] \\
\hline HPMC/Polyurethane & Silver and asiaticoside & Foam & $\begin{array}{l}\text { Increased absorption capacity and compressive strength } \\
\text { development; adequate antimicrobial activity. }\end{array}$ & [241] \\
\hline $\begin{array}{l}\text { HPMC/Chondroitin sulfate/Sodium } \\
\text { hyaluronate }\end{array}$ & Silver sulphadiazine & Sponge & $\begin{array}{l}\text { Proper elasticity, softness, flexibility, and bioadhesive properties, } \\
\text { alongside antibacterial activity. }\end{array}$ & [46] \\
\hline HPMC K100M/Gum Odina/Gelatin & Fluconazole and ofloxacin & Sponge & $\begin{array}{l}\text { The formulation with gum Odina-HPMC K100M:gelatin (1:1) } \\
\text { showed excellent physicochemical properties and antimicrobial } \\
\text { activity to cure chronic wounds. }\end{array}$ & [242] \\
\hline HPMC/HA/Methyl- $\beta$-cyclodextrin & Curcumin & Film & Excellent antimicrobial effect. & [243] \\
\hline $\begin{array}{l}\text { HPMC/Hydroxypropyl- } \beta- \\
\text { cyclodextrin/Chitosan }\end{array}$ & Caffeic acid & Hydrogel & $\begin{array}{l}\text { Drug delivery system with superabsorbent capacity, higher } \\
\text { swelling property at } \mathrm{pH} \text { 7, and good antimicrobial effect to } \\
\text { prevent wound infection. }\end{array}$ & [244] \\
\hline HPMC/Chitosan/Sodium alginate & $\begin{array}{l}\text { Lidocaine chloride and polymyxin B } \\
\text { sulphate }\end{array}$ & Biomembrane & $\begin{array}{l}\text { Proper mechanical properties (elasticity, tension, stiffness) and } \\
\text { thickness; in vivo: high antimicrobial effect for tissue } \\
\text { regeneration. }\end{array}$ & [245] \\
\hline $\begin{array}{l}\text { HPMC/Polyglycolic } \\
\text { acid/Vicryl }{ }^{\circledR} \text { /Catgut }\end{array}$ & Ofloxacin & Hydrogel & $\begin{array}{l}\text { Proper physicochemical properties, which ensures a high lesion } \\
\text { size contraction after } 14 \text { days ( } 95 \% \text { ) and large collagen deposition } \\
\text { on the } 21 \text { st day. }\end{array}$ & [246] \\
\hline
\end{tabular}

Abbreviations: AgNPs—Silver (Ag) nanoparticles, AuNPs—Gold (Au) nanoparticles, CuNPs—Copper (Cu) nanoparticles. 


\subsection{Methylcellulose-Based Wound Dressings}

Methylcellulose (MC) is a semi-synthetic and non-ionic polymer, a cellulose ether derivative with high solubility in water, which is influenced by temperature [247]. It forms through the etherification of cellulose molecule with methyl chloride or dimethyl sulfate in basic solution [27] when the hydroxyl groups from the mother molecule are substituted with methyl groups, which leads to a diminishing of crystallinity [248]. The chemical structure of MC is presented in Figure 9.

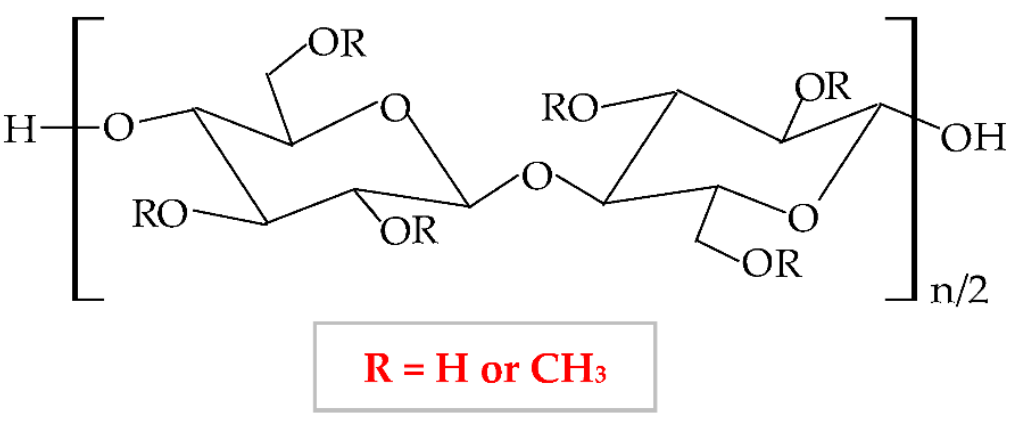

Figure 9. Chemical structure of methylcellulose (MC).

At a variation of temperature, $\mathrm{MC}$ has a thermo-sensitive behavior with a reversible sol-gel transition in an aqueous solution [249]. At a lower temperature than lower critical solution temperature, it realizes the hydration of the MC network in solution, with the formation of hydrogen bonds. At a higher temperature than lower critical solution temperature, the MC aqueous solution takes in the heat, with the disintegration of hydrogen bonds [195]. Thus, MC presents increased viscosity at higher temperatures, and at lower temperatures it exhibits a reduced viscosity [250].

The degree of substitution for commercial MC varies from 1.7 to 2.2 when it results in a semiflexible biopolymer because the inter-and intra- hydrogen bonds from cellulose molecule break off [251]. There are many substances, which influence the gelation behavior of MC, such as inorganics salts, ethanol, propylene glycol, polyethylene glycol 400, sucrose, glycerin, sorbitol, and different surfactants (sodium dodecyl sulfate and cetyltrimethylammonium bromide) [252]. MC is extensively used in biomedical, pharmaceutical, cosmetic, and food industries as a thickening, binding, and film-forming agent because it possesses excellent biocompatibility, biodegradability, and reduced toxicity [253-255].

To improve the characteristics of MC, it can be blended with other polymers in different ratios to enhance the physicochemical, morphological, and structural properties of both polymers and of the resulting composite [255]. Abu et al., illustrated that a higher concentration of MC led to increased hydrophilicity and porosity of the MC-chitosan scaffold due to the hydroxyl groups from the MC molecule, which can attract water molecules. The higher wettability has been described by the suitable results of the water uptake capacity [256]. Another combination of MC and chitosan was studied by Tan et al., They illustrated that an augmented concentration of MC led to improved tensile strength, moisture content, whitish index, and elongation at break [257]. El-Naggar et al., mixed MC with PVA and doxycycline hyclate (drug model) to develop a new drug delivery device, which showed a proper swelling capacity and a high drug release at basic medium [253]. The combination between $\mathrm{MC}$ and poly(acrylic acid) presented optimal mechanical properties and thermal stability [258]. The novel composite resulting by blending MC and tragacanth gum exhibited a higher capacity to form a gel and adequate mechanical and rheological properties [259]. MC can also be blended with diverse biopolymers and multiple bioactive agents (plants extracts, organic or inorganic substances, and chemical drugs) to develop a new potential wound dressing to accelerate the wound-healing process. All these mixtures are presented in Table 5. 
Table 5. Recent studies on the use of methylcellulose as a wound dressing.

\begin{tabular}{|c|c|c|c|c|}
\hline Biopolymer/-s & $\begin{array}{l}\text { Active Pharmaceutical Ingredient } \\
\text { (Natural or Synthetic Substances) }\end{array}$ & Type of Wound Dressing & Main Findings & References \\
\hline \multirow{8}{*}{ MC } & Zinc oxide and Silver & Ointment & $\begin{array}{c}\text { MC 3\% ointment showed an elastic behavior and thixotropy, which can be } \\
\text { used for injured skin with complex relief. }\end{array}$ & [260] \\
\hline & Allium hirtifolium & Gel & $\begin{array}{l}\text { In a ratio of 1:1, the newly developed gel accelerated the open wounds } \\
\text { healing through the tissue re-epithelialization. }\end{array}$ & [261] \\
\hline & $\begin{array}{l}\text { Cryopreserved human culture of fibroblasts } \\
\text { and AuNPs }\end{array}$ & Gel & $\begin{array}{l}\text { High capacity to heal the third-degree burns because it restored the } \\
\text { composition of type I and III collagen on 21st day of the treatment. }\end{array}$ & [262] \\
\hline & Vitamins $\left(\mathrm{C}, \mathrm{B}_{1}\right.$, and $\left.\mathrm{B}_{6}\right)$ & Hydrogel & $\begin{array}{c}\text { Enhanced gelation rate and mechanical strength, with suitable } \\
\text { applicability for wound treatment. }\end{array}$ & [263] \\
\hline & $\begin{array}{l}\text { Neomycin trisulphate, sulphacetamide } \\
\text { sodium, and Silver nitrate }\end{array}$ & Hydrogel & $\begin{array}{l}\text { New formulation exhibited elasticity, sponginess, homogenous texture, } \\
\text { proper smell, and white color. }\end{array}$ & [162] \\
\hline & Silver oxide nanoparticles & Hydrogel & $\begin{array}{l}\text { Thermo-responsive hydrogel, which led to wound burn regeneration due } \\
\text { to its superior antimicrobial effect. }\end{array}$ & [264] \\
\hline & Pedilanthus tithymaloides & Film & $\begin{array}{l}\text { A concentration of } 0.5 \% \text { of the plant extract accelerated the } \\
\text { re-epithelialization of the wounded skin. }\end{array}$ & [265] \\
\hline & AgNPSs & Film & $\begin{array}{l}\text { Increased water absorption capacity and contact angle value; the } \\
\text { temperature influenced the release of AgNPs. }\end{array}$ & [266] \\
\hline $\mathrm{MC} / \alpha$-Chitin nanocrystals & - & Hydrogel & $\begin{array}{l}\text { The novel nanocomposite presented high mechanical strength and gelation } \\
\text { rate, being a promising dressing for tissue engineering. }\end{array}$ & [267] \\
\hline MC/Fucoidan & - & Film & $\begin{array}{l}\text { The newly designed formulation could be a promising dressing for } \\
\text { wounds with a smaller production of exudates because it possessed a } \\
\text { lower capacity to swell. }\end{array}$ & [268] \\
\hline MC/Nano hyaluronic acid & - & Hydrogel & $\begin{array}{c}\text { The mixture of these polymers led to an in situ hydrogel development, } \\
\text { which enhanced tissue regeneration. }\end{array}$ & [269] \\
\hline MC/Mucin & - & Hydrogel & $\begin{array}{l}\text { MC enhanced the mechanical properties of the mucin and formed a } \\
\text { thermoresponsive gel, which can be used for different wounds treatment. }\end{array}$ & [270] \\
\hline $\begin{array}{l}\text { MC/2-Methacryloyloxy ethyl } \\
\text { phosphorylcholine }\end{array}$ & - & Hydrogel & It reduced the postoperative adhesion effect by inhibition of collagen proteins. & [271] \\
\hline MC/Gelatin/Gellan gum/PVP & - & Film & $\begin{array}{l}\text { The blend of all these polymers led to a novel wound dressing with suitable } \\
\text { physicochemical properties to restore minor lesions. }\end{array}$ & [272] \\
\hline \multirow[b]{2}{*}{ MC/Chitosan } & Adenosine and vitamin $C$ & Hydrogel & Thermo-responsive and self-healing ability and a higher release of adenosine. & [273] \\
\hline & Exosomes & Hydrogel & $\begin{array}{l}\text { Suitable mechanical properties, good gelation time, and excellent } \\
\text { self-healing for treatment of severe tissue injuries. }\end{array}$ & [274] \\
\hline
\end{tabular}


Table 5. Cont

\begin{tabular}{|c|c|c|c|c|}
\hline Biopolymer/-s & $\begin{array}{l}\text { Active Pharmaceutical Ingredient } \\
\text { (Natural or Synthetic Substances) }\end{array}$ & Type of Wound Dressing & Main Findings & References \\
\hline \multirow{2}{*}{ MC/Hyaluronic acid } & - & Gel & $\begin{array}{l}\text { It was shown that a low molecular weight of hyaluronic acid increased the } \\
\text { biocompatibility and the thermogelation of this new formulated composite. }\end{array}$ & [275] \\
\hline & AgNPs & Hydrogel & $\begin{array}{l}\text { Excellent morphological, swelling, and spectral properties, together with } \\
\text { the high antibacterial effect to treat burn wounds in children }(99.6 \%) \text {. }\end{array}$ & [276] \\
\hline $\mathrm{MC} / \mathrm{sECM}$ & Stem cells & Hydrogel & $\begin{array}{l}\text { At the wound site, the hydrogel had a thermosensitive sol-gel transition, } \\
\text { which accelerate the wound healing through neovascularization and } \\
\text { re-epithelialization. }\end{array}$ & [277] \\
\hline $\mathrm{MC} /$ Sericin & Tranilast & Ointment & $\begin{array}{l}\text { The combination of the two polymers and the antiallergic drug exhibited } \\
\text { excellent results to augment wound healing and to decrease the redness in } \\
\text { diabetic rats. }\end{array}$ & [278] \\
\hline MC/Silk fibroin & 5-Aminosalicylic acid & Hydrogel & $\begin{array}{l}\text { The gelation time of the novel composite has been enhanced by adding } \\
\text { MC; thus, this hydrogel presents important uses as a wound dressing and } \\
\text { drug release system. }\end{array}$ & [279] \\
\hline \multirow[b]{2}{*}{ MC/Sodium alginate } & $\begin{array}{l}\text { Manuka honey, aloe vera, and eucalyptus } \\
\text { essential oil }\end{array}$ & Hydrogel & $\begin{array}{l}\text { The formulation presented proper swelling capacity, biocompatibility, and } \\
\text { suitable antimicrobial and antibiofilm action. }\end{array}$ & [280] \\
\hline & Gallium $\left(\mathrm{Ga}^{3+}\right)$ & Hydrogel & $\begin{array}{l}\text { It was illustrated that this novel hydrogel is a promising dressing for } \\
\text { wounds infection prevention due to its large antibacterial action }(99.99 \%) \\
\text { and cytocompatibility. }\end{array}$ & [281] \\
\hline $\begin{array}{c}\text { MC/Sodium } \\
\text { alginate/Poly( } N \text {-isopropylacrylamide })\end{array}$ & Octenisept ${ }^{\circledR}$ & Hydrogel & $\begin{array}{l}\text { The novel hydrogel had a large viscosity, an expressed shear-thinning nature, } \\
\text { high antibacterial action, a homogenous and microporous structure. }\end{array}$ & [283] \\
\hline MC/Pluronic F-127 & GT/siMMP9 & Hydrogel & $\begin{array}{l}\text { It was demonstrated that this new dressing had thermosensitive traits by } \\
\text { forming in situ and it reduced the MMP-9 level in diabetic chronic injuries. }\end{array}$ & [284] \\
\hline MC/Polyacrylamide & Aloe barbadensis & Hydrogel & $\begin{array}{l}\text { At a } 2 \% \text { concentration of Aloe barbadensis, the hydrogel showed suitable } \\
\text { thermal stability; it also presented an antibacterial effect to cure chronic } \\
\text { cutaneous wounds. }\end{array}$ & [285] \\
\hline MC/Poly( $\varepsilon$-caprolactone) & Bioactive glass and Manuka honey & Fibers & $\begin{array}{l}\text { The blend of these two polymers led to higher mechanical properties } \\
\text { and wettability. }\end{array}$ & [286] \\
\hline \multirow[t]{2}{*}{$\mathrm{MC} / \mathrm{PVA}$} & Asiaticoside & Film & $\begin{array}{l}\text { This newly formulated dressing exhibited significant mechanical } \\
\text { properties, flexibility, transparency, and a shorter healing time of } \\
\text { skin wounds. }\end{array}$ & [287] \\
\hline & - & Nanofibers & $\begin{array}{l}\text { Adequate physicochemical features and antibacterial activity to be used as } \\
\text { a drug-delivery system for injuries management. }\end{array}$ & [288] \\
\hline
\end{tabular}

PVP-Polyvinylpyrrolidone, sECM-Soluble extracellular matrix. 


\subsection{Hydroxyethylcellulose-Based Wound Dressings}

Hydroxyethylcellulose (HEC) is a semi-synthetic, nonionic, and inert polymer, a watersoluble cellulose ether derivative [289]. It forms through etherification of alkaline cellulose with chlorohydrin or ethylene oxide, when hydroxyl groups from cellulose molecule are substituted with hydroxyethyl groups [290]. The chemical structure of HEC is illustrated in Figure 10.

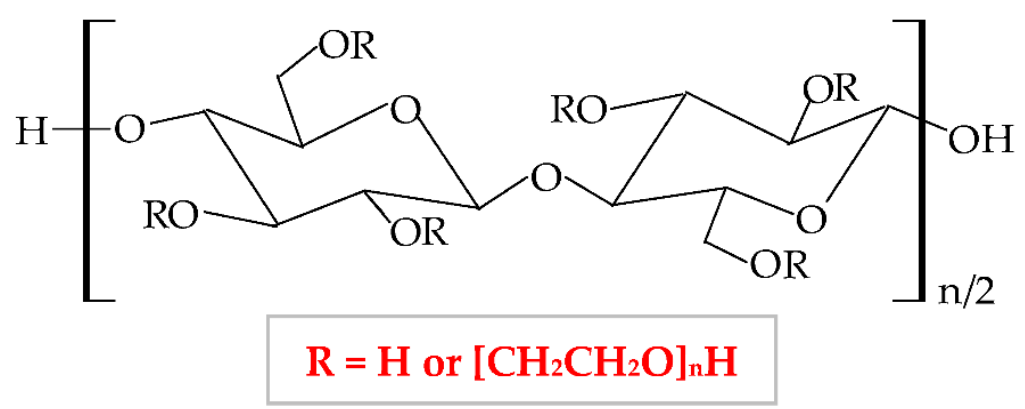

Figure 10. Chemical structure of hydroxyethylcellulose (HEC).

It has a low price, without taste and smell, with no color to light yellowish [291]; presents optimal stability at $\mathrm{pH}$ values between 2 and 12 [292]. HEC exhibits a proper capacity to scavenge free radicals and to form hydrogen and electrostatic bonds [293]. HEC is regarded as a hydrogel-like material, with two important characteristics: liquid-like and solid-like. Due to its polysaccharide structure, this hydrophilic biopolymer exhibits a high capacity to absorb and hold a large quantity of water or wound exudates. The elastic strength of its structure leads to an expansion of the molecule dimensions, without the modification of the structural stability and the gel form [294]. HEC possesses excellent physicochemical properties: rheological, hydrodynamic, and thermodynamic [295]. HEC also presents adequate biocompatibility, biodegradability, insignificant toxicity, immunogenicity, and cementing properties [296]. Due to its nonionic behavior, HEC exhibits the ability to coexist with a large field of other polymers, which have an appropriate solubility in water, salts, or surfactants. Therefore, HEC presents optimal toughness in a dielectric solution with a large concentration [297]. This biopolymer presents the largest commercial availability from all cellulose derivatives [298]; therefore, HEC is a noticeable biopolymer, which can be used successfully as an emulsifier, film-coating, stabilizer, suspender, and thickener agent in biomedical, pharmaceutical (wound dressing development) [299], cosmetic, food, adhesive, and textile industries [291,300,301]. The most predictive method for hydrogels synthesis is the crosslinking of free radicals generated by irradiation (electron beam and gamma-radiation) [302].

To enhance its properties, HEC can be blended with other polymers. For example, Zia et al., mixed HEC with poly(lactic acid) and polyurethane. They obtained a new composite with higher thermal stability and mechanical (tensile strength and elongation) properties compared to other polymers [303,304]. Moreover, HEC has been blended with polyvinyl alcohol (PVA), resulting in suitable electrical conductibility, viscoelasticity, stretchability, and thermosensitivity [305]. Guo et al., combined HEC with poly(caprolactone) by trimethylsilyl group technology and the result was the formation of a new copolymer with enhanced thermal properties [306]. HEC was also blended with chitosan to obtain a copolymer with improved physicochemical and mechanical characteristics [307], with gelatin to obtain a superparamagnetic composite [308], with sodium alginate to form a copolymer with enhanced swelling efficacy and drug delivery profile. HEC can also be combined with diverse biopolymers to formulate novel wound dressing, which can stimulate the wound healing process and restore the damaged skin. The main combinations are summarized in Table 6. 
Table 6. Recent studies on the use of hydroxyethylcellulose as a wound dressing.

\begin{tabular}{|c|c|c|c|c|}
\hline Biopolymer/-s & $\begin{array}{l}\text { Active Pharmaceutical Ingredient } \\
\text { (Natural or Synthetic Substances) }\end{array}$ & Type of Wound Dressing & Main Findings & References \\
\hline HEC & - & Hydrogel & $\begin{array}{l}\text { Good antibacterial effect; at a concentration between } 12.5 \% \\
\text { and } 15 \% \text { of HEC, the water absorption rate was the highest. }\end{array}$ & [309] \\
\hline \multirow{4}{*}{ HEC } & Curcuma longa & Hydrogel & $\begin{array}{l}\text { Suitable porous network, mechanical and release properties; } \\
\text { besides therapeutic effect, the new hydrogel can illustrate the } \\
\text { pH of the lesion site. }\end{array}$ & [310] \\
\hline & $\mathrm{WO}_{3}$ & Hydrogel & $\begin{array}{l}\text { The hydrogel with } 0.04 \% \mathrm{WO}_{3} \text { showed the highest capacity to } \\
\text { heal the injuries due to optimal antibacterial and } \\
\text { anti-inflammatory action. }\end{array}$ & [300] \\
\hline & Graphene oxide & Film & Improved mechanical and thermal properties. & [312] \\
\hline & AgNPs & Membrane & $\begin{array}{l}\text { Limited degradation rate, excellent porosity, and water } \\
\text { absorption value. }\end{array}$ & [313] \\
\hline HEC/Collagen & - & Film & $\begin{array}{l}\text { High swelling ratio, mechanical and thermal characteristics, } \\
\text { degradation, and adequate biocompatibility. }\end{array}$ & [314] \\
\hline HEC/Collagen/PVA & - & Nanofibers & $\begin{array}{l}\text { Suitable water absorption rate and degradation behavior, a } \\
\text { promising material for skin tissue engineering. }\end{array}$ & [315] \\
\hline HEC/Carboxymethyl chitosan & - & Hydrogel & $\begin{array}{l}\text { High biocompatibility, gelation time, water evaporation rate, } \\
\text { and swelling power. }\end{array}$ & [290] \\
\hline HEC/Sodium alginate/Hydroxyapatite & - & Membrane & $\begin{array}{l}\text { High porous network, improved mechanical strength, and } \\
\text { rigidity gradient. }\end{array}$ & [316] \\
\hline \multirow[t]{2}{*}{$\mathrm{HEC} /$ Hyaluronic acid } & - & Hydrogel & $\begin{array}{l}\text { Optimal biocompatibility and blood compatibility, gelation } \\
\text { time, water evaporation rate, water retention ability, and } \\
\text { swelling power. }\end{array}$ & [295] \\
\hline & Isoliquiritigenin & Hydrogel & $\begin{array}{l}\text { pH-sensitive hydrogel with suitable adhesion, rheological } \\
\text { properties, and antibacterial efficacy. }\end{array}$ & [317] \\
\hline
\end{tabular}




\subsection{Ethylcellulose-Based Wound Dressings}

Ethylcellulose (EC) is a nonionic semi-synthetic polymer, a cellulose ether derivative insoluble in water [318]. It forms through the etherification of alkali cellulose with ethyl chloride when the hydroxyl groups from cellulose molecule are substituted with ethyl groups [27]. The chemical structure of MC is presented in Figure 11.

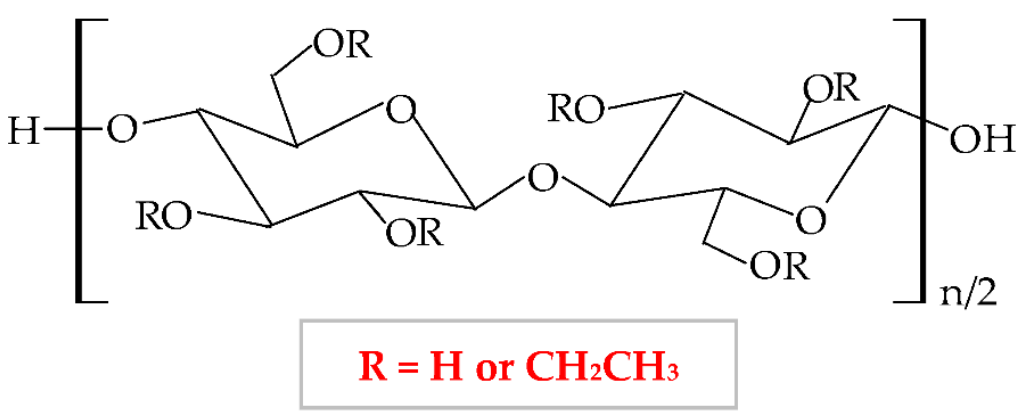

Figure 11. Chemical structure of ethylcellulose (EC).

This biopolymer presents numerous advantageous characteristics, such as mechanical properties, biodegradability, flexibility, low toxicity, hydrophobicity, gelling capacity [319], light, moisture, oxygen resistance, thermoplasticity [320], and low price, which make EC an excellent material for use in different industries (pharmaceutical, cosmetic and food) [321]. Moreover, this biopolymer has several particular features in addition to the other cellulose derivatives: high film-forming capacity, suitable chemical strength, and optimal mechanical properties [322]. EC represents the most extensively analyzed biopolymer due to its capacity to form film for coating solid pharmaceutical forms (tablets, microcapsules, and microspheres) and formulation of new topical forms [323]. EC is a promising material to be used for encapsulation due to its optimal optical transparency, processing temperature, and electronic insulation [324]. It also presents a good capacity to bind, preserve and dissolve [325], and possesses a proper control of drug delivery [326]. Films based on EC are brittle because of the stiffness of hydrogen linkages from its molecule. This biopolymer has high stability to chemical substances and can be associated with different plasticizers to design heavy and impermeable films [327].

EC can be mixed with various polymers to enhance the physicochemical and mechanical properties and thus, its applicability. To develop a novel drug-delivery device, Li et al., blended EC by electrospinning method with poly(di(ethylene glycol) methyl ether methacrylate), a thermosensitive polymer. The new formulation showed normal morphology, a large porosity, and an increased wettability at a higher temperature, which led to more hydrophobic behavior, causing an extended release of the drug [328]. EC was mixed with poly (ethylene-co-vinyl acetate) and resulted in a new composite with higher mechanical properties [329]. Chen et al., mixed EC and poly ( $\beta$-hydroxybutyrate) when EC acted as a thickening agent because it increased the viscosity of the new composite. In a concentration of 1\%, EC augmented the tensile strength [330]. Li et al., blended EC with konjac glucomannan to formulate a novel composite with higher mechanical properties, moisture resistance, permeability of oxygen, and stability at a high temperature [331]. EC was also associated with another cellulose derivative, HPC, and obtained a scaffold with enhanced mechanical properties and 3D printing capacity [332].

EC can also be combined with other polymers to develop new wound dressings, with enhanced physicochemical and mechanical properties that can accelerate the woundhealing process. Principal blends are presented in Table 7. 
Table 7. Recent studies on the use of ethylcellulose as a wound dressing.

\begin{tabular}{|c|c|c|c|c|}
\hline Biopolymer/-s & $\begin{array}{l}\text { Active Pharmaceutical Ingredient } \\
\text { (Natural or Synthetic Substances) }\end{array}$ & Type of Wound Dressing & Main Findings & References \\
\hline EC/Gum tragacanth & Honey & Nanofibers & $\begin{array}{l}\text { The ratio of } 85: 15 \text { with } 20 \% \text { honey showed the best } \\
\text { mechanical, biological, and antibacterial properties to } \\
\text { be used as an efficient wound dressing. }\end{array}$ & [321] \\
\hline $\mathrm{EC} / \mathrm{PVP}$ & Naproxen & Nanofibers & $\begin{array}{l}\text { The ratio of } 4: 1 \text { had the fastest release of the drug; thus, } \\
\text { it can be used as a dressing to reduce the inflammation } \\
\text { and the pain in acute wounds. }\end{array}$ & [333] \\
\hline EC/Poly(3-hydroxybutyrate) & $\begin{array}{l}\text { p-4-hydroxybenzoic acid and ferulic } \\
\text { acid }\end{array}$ & Film & $\begin{array}{l}\text { Potent bacteriostatic and bactericidal action to heal } \\
\text { wounds infection facilitating the skin restoration. }\end{array}$ & [335] \\
\hline EC/Polylactic acid/Collagen & Silver sulfadiazine & Nanofibers & $\begin{array}{l}\text { Good mechanical properties, proper antimicrobial } \\
\text { effect, and enhanced cell proliferation. }\end{array}$ & [336] \\
\hline $\mathrm{EC}$ & Ciprofloxacin & Nanofibers & $\begin{array}{l}\text { Cylindrical and homogenous aspect; high antibacterial } \\
\text { action. }\end{array}$ & [318] \\
\hline $\mathrm{EC} / \mathrm{PVA}$ & Luliconazole & Nanosponge & $\begin{array}{c}\text { Optimal viscosity, spreadability, retention time, } \\
\text { permeation rate, and also high antifungal effect against } \\
\text { dermatophytes. }\end{array}$ & [338] \\
\hline
\end{tabular}




\subsection{Hydroxypropylcellulose-Based Wound Dressings}

Hydroxypropyl cellulose (HPC) is a semi-synthetic hydrophilic polymer, a cellulose ether derivative, with proper solubility in water and organic solvents [339]. Its solubility depends on the degree of substitution. At values smaller than $12 \%$, HPC is water-soluble and at values higher than $12 \%, \mathrm{HPC}$ is ethanol-soluble [340]. This biopolymer results from the etherification reaction of alkali cellulose with 1,2-propylene oxide. Thus, the 2,3,6hydroxyl groups from the cellulose molecule are replaced with hydroxypropyl groups [27]. The chemical structure of HPC is presented in Figure 12.

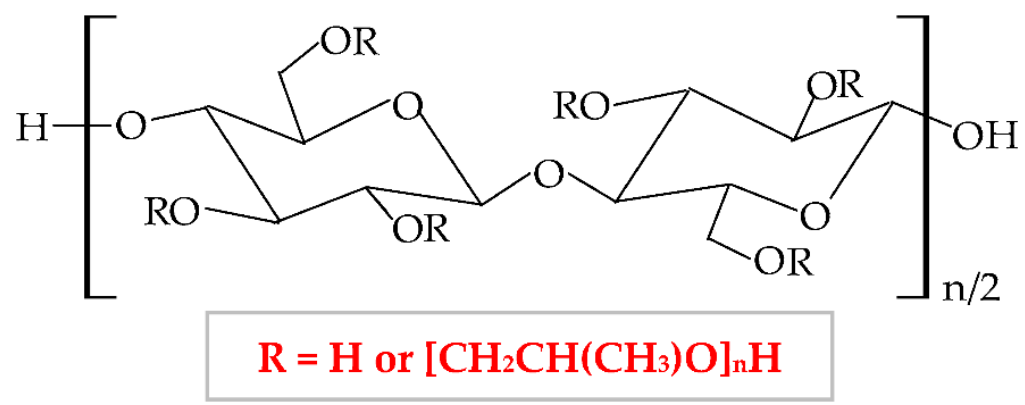

Figure 12. Chemical structure of hydroxypropylcellulose (HPC).

It has numerous advantageous properties, such as amphiphilicity, low price, electrical neutrality, biocompatibility, biodegradability, non-toxicity, high power of swelling the wounds exudate [341,342], adequate chemical strength, and film-forming efficiency [236]. At a high temperature and in a concentrated aqueous solution, HPC generates a cholesteric liquid crystalline network, depending on its concentration [343]. HPC exhibits a thermoplastic behavior and develops temperature-responsive hydrogels [195,344]. Regarding the HPC-based films, these are defined by high flexibility, good impermeability for oil and fat, and a low value of $\mathrm{T}_{\mathrm{g}}$ (glass transition temperature) at excessive humidity. The LCST (lower critical solution temperature) water value is about $41^{\circ} \mathrm{C}$. At a slightly higher temperature than LCST, HPC presents a phase change because the water solution of this biopolymer generates metastable nanosphere aggregates [345]. Moreover, the solubility of HPC is influenced by LCST values. At a lower temperature than LCST, HPC dissolves easily in water and at a higher temperature than LCST, HPC does not dissolve [346]. Thus, this cellulose derivative is an optimal material to be used in biomedical and pharmaceutical fields as a binding, disintegrating, emulsifying, thickening, filler, and coating agent $[347,348]$ and in the construction domain [349]. It can also be used in the food industry because the United States Food and Drug Administration (FDA) authorized HPC as a safe food additive [350].

HPC can be blended with other polymers to improve the physicochemical and mechanical properties and thus, to extend its applicability. For instance, Veerapur et al., combined HPC and chitosan, and the new formulated composite presented higher hydrophilicity, swelling capacity, and permeation rate [351]. By mixing HPC with cellulose acetate phthalate resulted a composite with higher properties than compounds: increased pseudoplasticity and viscoelastic behavior [352]. Gan et al., prepared a high-performance hydrogel with enhanced tensile strength, toughness, biocompatibility, wear resistance, and low friction coefficient from HPC, sodium alginate, and poly(vinyl alcohol); these excellent characteristics extend the area of use to biosensors and nerve replacement [353]. Lu et al., blended HPC with poly(vinyl alcohol) to obtain a new scaffold with augmented toughness, elasticity, conductivity, and mechanical strength that is a promising material for the development of biosensors and interaction between humans and machines [354]. HPC can also be mixed with other polymers to develop novel wound dressing, with higher physicochemical traits that can restore the impaired skin tissue. The main combinations are summarized in Table 8. 
Table 8. Recent studies on the use of hydroxypropylcellulose as a wound dressing.

\begin{tabular}{|c|c|c|c|c|}
\hline Biopolymer/-s & $\begin{array}{l}\text { Active Pharmaceutical Ingredient } \\
\text { (Natural or Synthetic Substances) }\end{array}$ & Type of Wound Dressing & Main Findings & References \\
\hline \multirow{3}{*}{$\mathrm{HPC}$} & Peptide PXL150 & Gel & $\begin{array}{l}\text { Due to the antimicrobial activity, the gel healed the infection } \\
\text { of third-degree burns injuries and surgical wounds. }\end{array}$ & [355] \\
\hline & - & Hydrogel & $\begin{array}{l}\text { Suitable water absorption; the hydrogel can maintain an } \\
\text { adequate moisture balance at the lesion site. }\end{array}$ & [339] \\
\hline & $\begin{array}{l}\text { Graphene oxide, Isophorone } \\
\text { diisocyanate, and } \mathrm{Ag} / \mathrm{ZnO}\end{array}$ & Film & $\begin{array}{l}\text { Higher mechanical, anti-ultraviolet properties, and } \\
\text { antimicrobial activity. }\end{array}$ & [356] \\
\hline HPC/Gelatin & Chloramphenicol & Hydrogel & $\begin{array}{l}\text { Adequate mechanical strength, water vapor permeability, } \\
\text { light transmittance, and excellent antibacterial effect. }\end{array}$ & [357] \\
\hline HPC/Chitosan/PEO & Graphene & Membrane & $\begin{array}{l}\text { Proper mechanical properties, hydrophilicity, water vapor } \\
\text { transmission rate, and high antibacterial effect; the membrane } \\
\text { can impede the bacterial adhesion. }\end{array}$ & [341] \\
\hline HPC/Sodium alginate & Gatifloxacin & Hydrogel & $\begin{array}{l}\text { Advantageous physicochemical properties regarding the } \\
\text { tensile strength, the swelling capacity, the elongation, and the } \\
\text { drug release. }\end{array}$ & [236] \\
\hline
\end{tabular}




\subsection{Combinations of Cellulose Derivatives-Based Wound Dressings}

One or more cellulose derivatives may combine with other cellulose derivatives to formulate novel wound dressings, with enhanced properties that can accelerate the woundhealing process and alleviate the pain, inflammation, and stress caused by damaged skin tissue. Moreover, they can be combined to counteract their drawbacks [75]. The main combinations are summarized in Table 9.

Table 9. Recent studies on the use of combinations of cellulose derivatives as wound dressing.

\begin{tabular}{|c|c|c|c|c|}
\hline Biopolymer/-s & $\begin{array}{l}\text { Active Pharmaceutical Ingredient } \\
\text { (Natural or Synthetic Substances) }\end{array}$ & Type of Wound Dressing & Main Findings & References \\
\hline \multirow[b]{2}{*}{ EC/HPMC } & Paromomycin and Gentamicin & Film & $\begin{array}{l}\text { Optimum drugs release and } \\
\text { inhibition of Leishmania tropica growth. }\end{array}$ & {$[359]$} \\
\hline & Aloe vera & Nanofibers & $\begin{array}{c}\text { Nanofibers with } 10 \% \text { Aloe vera } \\
\text { showed suitable mechanical } \\
\text { properties, biocompatibility, } \\
\text { bioadhesion, and suitable } \\
\text { antibacterial activity. }\end{array}$ & [360] \\
\hline \multirow{4}{*}{$\mathrm{NaCMC} / \mathrm{HPMC}$} & Grapefruit seed extract & Film & $\begin{array}{l}\text { Suitable elongation at break, stability in } \\
\text { water, and proper antibacterial action. }\end{array}$ & {$[361]$} \\
\hline & $\mathrm{CuO}$ & Film & $\begin{array}{l}\text { Good biocompatibility and } \\
\text { antibacterial effect. }\end{array}$ & {$[362]$} \\
\hline & Tetracycline/Methylene blue & Film & $\begin{array}{l}\text { Nanoporous network, increased } \mathrm{T}_{\mathrm{g}} \\
\text { and elongation at break, sustained } \\
\text { drug release for } 72 \mathrm{~h} \text { and high } \\
\text { antibacterial effect. }\end{array}$ & {$[363]$} \\
\hline & $\mathrm{ZnO}$ NPs & Film & $\begin{array}{l}\text { Biocompatibility and optimum } \\
\text { antibacterial action. }\end{array}$ & {$[364]$} \\
\hline $\begin{array}{l}\mathrm{NaCMC} / \mathrm{HPMC} / \\
\mathrm{CAB}\end{array}$ & Resveratrol & Membrane & $\begin{array}{l}\text { Excellent adhesive capacity, hydration } \\
\text { efficiency, and higher porous } \\
\text { structure; in vivo studies showed } \\
\text { accelerated wound healing. }\end{array}$ & {$[365]$} \\
\hline $\mathrm{NaCMC} / \mathrm{MC}$ & Simvastatin & Membrane & $\begin{array}{l}\text { In a ratio of 2:1, the membrane } \\
\text { exhibited appropriate flexibility, } \\
\text { viscosity, stability, and sponginess; } \\
\text { optimal drug delivery for } \\
\text { suppurating injuries. }\end{array}$ & {$[366]$} \\
\hline
\end{tabular}

Abbreviations: $\mathrm{CAB}$ —Cellulose acetate butyrate, $\mathrm{CuO}$ —Copper oxide, $\mathrm{T}_{\mathrm{g}}$-Glass transition temperature, $\mathrm{ZnO}$ NPs—Zinc oxide nanoparticles.

\section{Conclusions and Future Perspectives}

This review has focused on different types of wound dressing (gel, hydrogel, sponge, hydrocolloid, film, membrane, foam, and nanofibers) based on cellulose derivatives as biopolymeric scaffolds, and various bioactive agents, from plant extracts to chemical drugs. We have considered the cellulose ethers derivatives (NaCMC, HPMC, MC, HEC, EC, and HPC). It has been illustrated that cellulose derivatives can manifest a therapeutic effect on wound healing, alone or in combination with other natural, semi-synthetic, and synthetic polymers. The major advantage of mixing two or more biopolymers is, besides the beneficial action on damaged tissue, the improvement of physicochemical properties of the novel dressing. Cellulose derivatives have a particular chemical structure, obtained by etherification of hydroxyl groups from cellulose molecule with different alkyl groups, the consequence being the improvement of water solubility. Therefore, these biopolymers can be successfully used as a base for diverse formulations, due to their high gelation properties. Cellulose derivatives exhibit an efficient capacity to absorb the exudates on the site of the lesion, retain them, and swell. Consequently, the newly formulated wound dressings show an excellent ability to maintain relevant moisture on the wound bed and allow gas exchanges with the environment. Due to their high biocompatibility, biodegradability, physicochemical properties, eco-friendliness, and low cost, cellulose derivatives are promising materials for biomedical and pharmaceutical domains (electrochemical biosensors for medical diagnosis, bone tissue engineering, hemodialysis, drug delivery and 3D printing), for oilfields, carbon capture and the food industry. 
Author Contributions: The authors had equal contribution. All authors have read and agreed to the published version of the manuscript.

Funding: This paper was financially supported by the Carol Davila University of Medicine and Pharmacy Bucharest through Contract No. CNFIS-FDI-2021-0300 and RDI Capability consolidation at the Institutional level of the multidisciplinary research teams involved in the sustainability of UMFCD priority research directions.

Institutional Review Board Statement: Not applicable.

Informed Consent Statement: Not applicable.

Data Availability Statement: No new data were created or analyzed in this study. Data sharing is not applicable to this article.

Conflicts of Interest: The authors declare no conflict of interest.

\section{References}

1. Kim, B.S.; Gao, G.; Kim, J.Y.; Cho, D.W. 3D Cell Printing of Perfusable Vascularized Human Skin Equivalent Composed of Epidermis, Dermis, and Hypodermis for Better Structural Recapitulation of Native Skin. Adv. Healthc. Mater. 2019, 8, e1801019. [CrossRef] [PubMed]

2. Sadeghi, S.; Nourmohammadi, J.; Ghaee, A.; Soleimani, N. Carboxymethyl cellulose-human hair keratin hydrogel with controlled clindamycin release as antibacterial wound dressing. Int. J. Biol. Macromol. 2020, 147, 1239-1247. [CrossRef] [PubMed]

3. Zimmerman, A.; Bai, L.; Ginty, D.D. The gentle touch receptors of mammalian skin. Science 2014, 346, 950-954. [CrossRef] [PubMed]

4. Zhao, S.; Li, L.; Wang, H.; Zhang, Y.; Cheng, X.; Zhou, N.; Rahaman, M.N.; Liu, Z.; Huang, W.; Zhang, C. Wound dressings composed of copper-doped borate bioactive glass microfibers stimulate angiogenesis and heal full-thickness skin defects in a rodent model. Biomaterials 2015, 53, 379-391. [CrossRef]

5. Kilic Bektas, C.; Kimiz, I.; Sendemir, A.; Hasirci, V.; Hasirci, N. A bilayer scaffold prepared from collagen and carboxymethyl cellulose for skin tissue engineering applications. J. Biomater. Sci. Polym. Ed. 2018, 29, 1764-1784. [CrossRef]

6. Kolarsick, P.A.; Kolarsick, M.A.; Goodwin, C. Anatomy and physiology of the skin. J. Dermatol. Nurses Assoc. $2011,3,203-213$. [CrossRef]

7. McLafferty, E.; Hendry, C.; Alistair, F. The integumentary system: Anatomy, physiology and function of skin. Nurs. Stand. 2012, 27, 35-42. [CrossRef]

8. Joodaki, H.; Panzer, M.B. Skin mechanical properties and modeling: A review. Proc. Inst. Mech. Eng. Part H J. Eng. Med. 2018, 232, 323-343. [CrossRef]

9. Lai-Cheong, J.E.; McGrath, J.A. Structure and function of skin, hair and nails. Medicine 2021, 49, 337-342. [CrossRef]

10. Brown, T.M.; Krishnamurthy, K. Histology, Dermis. In StatPearls; StatPearls Publishing LLC.: Treasure Island, FL, USA, 2020.

11. Hashmi, S.; Marinkovich, M.P. Molecular organization of the basement membrane zone. Clin. Dermatol. 2011, $29,398-411$. [CrossRef]

12. Zimoch, J.; Zielinska, D.; Michalak-Micka, K.; Rütsche, D.; Böni, R.; Biedermann, T.; Klar, A.S. Bioengineering a prevascularized human tri-layered skin substitute containing a hypodermis. Acta Biomater. 2021, 134, 215-227. [CrossRef]

13. Wong, R.; Geyer, S.; Weninger, W.; Guimberteau, J.C.; Wong, J.K. The dynamic anatomy and patterning of skin. Exp. Dermatol. 2016, 25, 92-98. [CrossRef] [PubMed]

14. Bragazzi, N.L.; Sellami, M.; Salem, I.; Conic, R.; Kimak, M.; Pigatto, P.D.M.; Damiani, G. Fasting and Its Impact on Skin Anatomy, Physiology, and Physiopathology: A Comprehensive Review of the Literature. Nutrients 2019, 11, 249. [CrossRef] [PubMed]

15. Rodrigues, C.; de Assis, A.M.; Moura, D.J.; Halmenschlager, G.; Saffi, J.; Xavier, L.L.; Fernandes Mda, C.; Wink, M.R. New therapy of skin repair combining adipose-derived mesenchymal stem cells with sodium carboxymethylcellulose scaffold in a pre-clinical rat model. PLoS ONE 2014, 9, e96241. [CrossRef]

16. Okoye, E.; Okolie, T. Development and in vitro characterization of ciprofloxacin loaded polymeric films for wound dressing. Int. J. Health Allied Sci. 2015, 4, 234. [CrossRef]

17. Varshosaz, J.; Taymouri, S.; Minaiyan, M.; Rastegarnasab, F.; Baradaran, A. Development and in vitro/in vivo evaluation of HPMC/chitosan gel containing simvastatin loaded self-assembled nanomicelles as a potent wound healing agent. Drug Dev. Ind. Pharm. 2018, 44, 276-288. [CrossRef]

18. Martinengo, L.; Olsson, M.; Bajpai, R.; Soljak, M.; Upton, Z.; Schmidtchen, A.; Car, J.; Jarbrink, K. Prevalence of chronic wounds in the general population: Systematic review and meta-analysis of observational studies. Ann. Epidemiol. 2019, 29, 8-15. [CrossRef]

19. Sen, C.K. Human Wound and Its Burden: Updated 2020 Compendium of Estimates. Adv. Wound Care 2021, 10, 281-292. [CrossRef]

20. Walker, J.; Cullen, M.; Chambers, H.; Mitchell, E.; Steers, N.; Khalil, H. Identifying wound prevalence using the Mobile Wound Care program. Int. Wound J. 2014, 11, 319-325. [CrossRef]

21. Kapp, S.; Miller, C.; Santamaria, N. The quality of life of people who have chronic wounds and who self-treat. J. Clin. Nurs. 2018, 27, 182-192. [CrossRef] 
22. Moreira, M.E.; Markovchick, V.J. Wound Management. Crit. Care Nurs. Clin. N. Am. 2012, 24, 215-237. [CrossRef]

23. Ghica, M.V.; Kaya, M.G.A.; Dinu-Pirvu, C.E.; Lupuleasa, D.; Udeanu, D.I. Development, Optimization and In Vitro/In Vivo Characterization of Collagen-Dextran Spongious Wound Dressings Loaded with Flufenamic Acid. Molecules 2017, $22,1552$. [CrossRef] [PubMed]

24. Clark, M. Alginates in Dressings and Wound Management. In Alginates and Their Biomedical Applications; Rehm, B.H.A., Moradali, M.F., Eds.; Springer Series in Biomaterials Science and Engineering; Springer: Berlin/Heidelberg, Germany, 2018; Volume 11, pp. $213-222$.

25. Aramwit, P. Introduction to biomaterials for wound healing. In Wound Healing Biomaterials, Vol. 2: Functional Biomaterials; Agren, M.S., Ed.; Woodhead Publishing Series in Biomaterials; Woodhead Publ. Ltd.: Cambridge, UK, 2016; Volume 115, pp. 3-38.

26. Lee, D.; Yoo, B. Cellulose derivatives agglomerated in a fluidized bed: Physical, rheological, and structural properties. Int. J. Biol. Macromol. 2021, 181, 232-240. [CrossRef]

27. Seddiqi, H.; Oliaei, E.; Honarkar, H.; Jin, J.F.; Geonzon, L.C.; Bacabac, R.G.; Klein-Nulend, J. Cellulose and its derivatives: Towards biomedical applications. Cellulose 2021, 28, 1893-1931. [CrossRef]

28. Jia, B.; Zhou, J.; Zhang, L. Electrospun nano-fiber mats containing cationic cellulose derivatives and poly (vinyl alcohol) with antibacterial activity. Carbohydr. Res. 2011, 346, 1337-1341. [CrossRef]

29. Oprea, M.; Voicu, S.I. Recent advances in composites based on cellulose derivatives for biomedical applications. Carbohydr. Polym. 2020, 247, 116683. [CrossRef] [PubMed]

30. Agrawal, P.; Soni, S.; Mittal, G.; Bhatnagar, A. Role of polymeric biomaterials as wound healing agents. Int. J. Low Extrem. Wounds 2014, 13, 180-190. [CrossRef]

31. Mir, M.; Ali, M.N.; Barakullah, A.; Gulzar, A.; Arshad, M.; Fatima, S.; Asad, M. Synthetic polymeric biomaterials for wound healing: A review. Prog Biomater 2018, 7, 1-21. [CrossRef] [PubMed]

32. Shende, P.; Gupta, H. Formulation and comparative characterization of nanoparticles of curcumin using natural, synthetic and semi-synthetic polymers for wound healing. Life Sci. 2020, 253, 117588. [CrossRef] [PubMed]

33. Boateng, J.S.; Matthews, K.H.; Stevens, H.N.; Eccleston, G.M. Wound healing dressings and drug delivery systems: A review. J. Pharm. Sci. 2008, 97, 2892-2923. [CrossRef]

34. Serena, T.E. A Global Perspective on Wound Care. Adv. Wound Care 2014, 3, 548-552. [CrossRef]

35. Ambekar, R.S.; Kandasubramanian, B. Advancements in nanofibers for wound dressing: A review. Eur. Polym. J. 2019, 117, 304-336. [CrossRef]

36. Kordestani, S.S. Chapter 6-Wound Classification. In Atlas of Wound Healing; Kordestani, S.S., Ed.; Elsevier: Amsterdam, The Netherlands, 2019; pp. 49-50.

37. Kumar, K.S.; Reddy, B.E.J.S.; Processing, I. Wound image analysis classifier for efficient tracking of wound healing status. Signal Image Process. 2014, 5, 15-27.

38. Wang, M.; Huang, X.; Zheng, H.; Tang, Y.; Zeng, K.; Shao, L.; Li, L. Nanomaterials applied in wound healing: Mechanisms, limitations and perspectives. J. Control. Release 2021, 337, 236-247. [CrossRef] [PubMed]

39. Low, J.S.; Mak, K.-K.; Zhang, S.; Pichika, M.R.; Marappan, P.; Mohandas, K.; Balijepalli, M.K. In vitro methods used for discovering plant derived products as wound healing agents-An update on the cell types and rationale. Fitoterapia 2021, 154, 105026. [CrossRef] [PubMed]

40. Nosrati, H.; Khodaei, M.; Alizadeh, Z.; Banitalebi-Dehkordi, M. Cationic, anionic and neutral polysaccharides for skin tissue engineering and wound healing applications. Int. J. Biol. Macromol. 2021, 192, 298-322. [CrossRef] [PubMed]

41. Skorkowska-Telichowska, K.; Czemplik, M.; Kulma, A.; Szopa, J. The local treatment and available dressings designed for chronic wounds. J. Am. Acad. Dermatol. 2013, 68, e117-e126. [CrossRef] [PubMed]

42. Thomas, S. Surgical Dressings and Wound Management; Dr Stephen Thomas: Joplin, MI, USA, 2010.

43. Hachem, R.; Parikh, U.M.; Reitzel, R.; Rosenblatt, J.; Kaul, A.; Vargas-Cruz, N.; Hill, L.; Moore, L.; Meyer, J.; Chaftari, A.M.; et al. Novel antimicrobial ointment for infected wound healing in an in vitro and in vivo porcine model. Wound Repair Regen. 2021, 29, 830-842. [CrossRef]

44. Albu, M.G.; Ghica, M.V.; Stefanescu, G.A.; Hodorogea, M.; Marin, M.M.; Marin, S.; Danila, E.; Voicu, S.; Simonca, A.G.; Popa, L. Design and Characterization of Collagen-Sodium Carboxymethylcellulose-Lidocaine 3D Composites for Wound Management. Key Eng. Mater. 2016, 695, 309-316. [CrossRef]

45. Capanema, N.S.V.; Mansur, A.A.P.; de Jesus, A.C.; Carvalho, S.M.; de Oliveira, L.C.; Mansur, H.S. Superabsorbent crosslinked carboxymethyl cellulose-PEG hydrogels for potential wound dressing applications. Int. J. Biol. Macromol. 2018, 106, 1218-1234. [CrossRef]

46. Sandri, G.; Bonferoni, M.C.; D’Autilia, F.; Rossi, S.; Ferrari, F.; Grisoli, P.; Sorrenti, M.; Catenacci, L.; Del Fante, C.; Perotti, C.; et al. Wound dressings based on silver sulfadiazine solid lipid nanoparticles for tissue repairing. Eur. J. Pharm. Biopharm. 2013, 84, 84-90. [CrossRef] [PubMed]

47. Cañedo-Dorantes, L.; Cañedo-Ayala, M. Skin Acute Wound Healing: A Comprehensive Review. Int. J. Inflamm. 2019, 2019, 3706315. [CrossRef] [PubMed]

48. Verma, Y.K.; Verma, R.; Sing, A.K.; Gangenahalli, G. LiCl Containing Thermosensitive Formulation Improves Hemostasis, Wound Healing, and Hair Regrowth. Regen. Eng. Transl. Med. 2020, 17, 362-378. [CrossRef]

49. Kenet, G.; Barg, A.A.; Nowak-Gottl, U. Hemostasis in the Very Young. Semin. Thromb. Hemost. 2018, 44, 617-623. [CrossRef] [PubMed] 
50. Iacob, A.T.; Dragan, M.; Ionescu, O.M.; Profire, L.; Ficai, A.; Andronescu, E.; Confederat, L.G.; Lupascu, D. An Overview of Biopolymeric Electrospun Nanofibers Based on Polysaccharides for Wound Healing Management. Pharmaceutics 2020, $12,983$. [CrossRef]

51. Kanikireddy, V.; Varaprasad, K.; Jayaramudu, T.; Karthikeyan, C.; Sadiku, R. Carboxymethyl cellulose-based materials for infection control and wound healing: A review. Int. J. Biol. Macromol. 2020, 164, 963-975. [CrossRef]

52. Pawar, H.V.; Tetteh, J.; Boateng, J.S. Preparation, optimisation and characterisation of novel wound healing film dressings loaded with streptomycin and diclofenac. Colloid Surf. B Biointerfaces 2013, 102, 102-110. [CrossRef]

53. Harper, D.; Young, A.; McNaught, C.-E.J.S. The physiology of wound healing. Adv. Ski. Wound Care 2014, 32, 445-450. [CrossRef]

54. Yang, L.; Liang, F.; Zhang, X.; Jiang, Y.; Duan, F.; Li, L.; Ren, F. Remodeling microenvironment based on MOFs-Hydrogel hybrid system for improving diabetic wound healing. Chem. Eng. J. 2022, 427, 131506. [CrossRef]

55. Schreml, S.; Szeimies, R.; Prantl, L.; Karrer, S.; Landthaler, M.; Babilas, P.J. Oxygen in acute and chronic wound healing. Br. J. Dermatol. 2010, 163, 257-268. [CrossRef]

56. El-Ashram, S.; El-Samad, L.M.; Basha, A.A.; El Wakil, A. Naturally-derived targeted therapy for wound healing: Beyond classical strategies. Pharmacol. Res. 2021, 170, 105749. [CrossRef] [PubMed]

57. Guo, S.; Dipietro, L.A. Factors affecting wound healing. J. Dent. Res. 2010, 89, 219-229. [CrossRef]

58. Khalil, H.; Cullen, M.; Chambers, H.; Carroll, M.; Walker, J. Elements affecting wound healing time: An evidence based analysis. Wound Repair Regen. 2015, 23, 550-556. [CrossRef]

59. Desmet, C.M.; Preat, V.; Gallez, B. Nanomedicines and gene therapy for the delivery of growth factors to improve perfusion and oxygenation in wound healing. Adv. Drug Deliv. Rev. 2018, 129, 262-284. [CrossRef]

60. Gueldner, J.; Zhang, F.; Zechmann, B.; Bruce, E.D. Evaluating a novel oxygenating therapeutic for its potential use in the advancement of wound healing. Toxicol. In Vitro 2017, 43, 62-68. [CrossRef] [PubMed]

61. Paunica-Panea, G.; Ficai, A.; Marin, M.M.; Marin, S.; Albu, M.G.; Constantin, V.D.; Dinu-Pirvu, C.; Vuluga, Z.; Corobea, M.C.; Ghica, M.V. New Collagen-Dextran-Zinc Oxide Composites for Wound Dressing. J. Nanomater. 2016, 2016, 5805034. [CrossRef]

62. Powers, J.G.; Higham, C.; Broussard, K.; Phillips, T.J. Wound healing and treating wounds Chronic wound care and management. J. Am. Acad. Dermatol. 2016, 74, 607-625. [CrossRef]

63. Emmerson, E.; Hardman, M.J. The role of estrogen deficiency in skin ageing and wound healing. Biogerontology 2012, 13, 3-20. [CrossRef]

64. Gouin, J.P.; Kiecolt-Glaser, J.K. The Impact of Psychological Stress on Wound Healing: Methods and Mechanisms. Crit. Care Nurs. Clin. N. Am. 2012, 24, 201-213. [CrossRef]

65. Okonkwo, U.A.; DiPietro, L.A. Diabetes and Wound Angiogenesis. Int. J. Mol. Sci. 2017, 18, 1419. [CrossRef]

66. Goodarzi, P.; Alavi-Moghadam, S.; Sarvari, M.; Beik, A.T.; Falahzadeh, K.; Aghayan, H.; Payab, M.; Larijani, B.; Gilany, K.; Rahim, F.; et al. Adipose Tissue-Derived Stromal Cells for Wound Healing. In Cell Biology and Translational Medicine, Vol. 4: Stem Cells and Cell Based Strategies in Regeneration; Turksen, K., Ed.; Advances in Experimental Medicine and Biology; Springer International Publishing AG: Cham, Switzerland, 2018; Volume 1119, pp. 133-149.

67. Serra, M.B.; Barroso, W.A.; Silva, N.N.; Silva, S.d.N.; Borges, A.C.R.; Abreu, I.C.; Borges, M.O.d.R. From Inflammation to Current and Alternative Therapies Involved in Wound Healing. Int. J. Inflamm. 2017, 2017, 3406215. [CrossRef] [PubMed]

68. Beyene, R.T.; Derryberry, S.L.; Barbul, A. The Effect of Comorbidities on Wound Healing. Surg. Clin. N. Am. 2020, 100, 695-705. [CrossRef] [PubMed]

69. McDaniel, J.C.; Browning, K.K. Smoking, chronic wound healing, and implications for evidence-based practice. J. Wound Ostomy Cont. Nurs. 2014, 41, 415-423. [CrossRef] [PubMed]

70. Sen, C.K. Human Wounds and Its Burden: An Updated Compendium of Estimates. Adv. Wound Care 2019, 8, 39-48. [CrossRef] [PubMed]

71. Moura, L.I.; Dias, A.M.; Carvalho, E.; de Sousa, H.C. Recent advances on the development of wound dressings for diabetic foot ulcer treatment-A review. Acta Biomater. 2013, 9, 7093-7114. [CrossRef]

72. Kus, K.J.B.; Ruiz, E.S. Wound Dressings-A Practical Review. Curr. Dermatol. Rep. 2020, 9, 298-308. [CrossRef]

73. Mogoşanu, G.D.; Grumezescu, A.M. Natural and synthetic polymers for wounds and burns dressing. Int. J. Pharm. 2014, 463, 127-136. [CrossRef]

74. Namazi, H.; Rakhshaei, R.; Hamishehkar, H.; Kafil, H.S. Antibiotic loaded carboxymethylcellulose/MCM-41 nanocomposite hydrogel films as potential wound dressing. Int. J. Biol. Macromol. 2016, 85, 327-334. [CrossRef]

75. Trevisol, T.C.; Fritz, A.R.M.; de Souza, S.M.A.G.U.; Bierhalz, A.C.K.; Valle, J.A.B. Alginate and carboxymethyl cellulose in monolayer and bilayer films as wound dressings: Effect of the polymer ratio. J. Appl. Polym. Sci. 2019, 136, 46941. [CrossRef]

76. Mishra, S.K.; Mary, D.S.; Kannan, S. Copper incorporated microporous chitosan-polyethylene glycol hydrogels loaded with naproxen for effective drug release and anti-infection wound dressing. Int. J. Biol. Macromol. 2017, 95, 928-937. [CrossRef]

77. Kamoun, E.A.; Chen, X.; Mohy Eldin, M.S.; Kenawy, E.-R.S. Crosslinked poly(vinyl alcohol) hydrogels for wound dressing applications: A review of remarkably blended polymers. Arab. J. Chem. 2015, 8, 1-14. [CrossRef]

78. Patil, P.P.; Reagan, M.R.; Bohara, R.A. Silk fibroin and silk-based biomaterial derivatives for ideal wound dressings. Int. J. Biol. Macromol. 2020, 164, 4613-4627. [CrossRef] [PubMed]

79. Dhivya, S.; Padma, V.V.; Santhini, E. Wound dressings—A review. Biomedicine 2015, 5, 22. [CrossRef] [PubMed] 
80. Marin, S.; Albu Kaya, M.G.; Ghica, M.V.; Dinu-Pirvu, C.; Popa, L.; Udeanu, D.I.; Mihai, G.; Enachescu, M. Collagen-Polyvinyl Alcohol-Indomethacin Biohybrid Matrices as Wound Dressings. Pharmaceutics 2018, 10, 224. [CrossRef] [PubMed]

81. Akrami-Hasan-Kohal, M.; Tayebi, L.; Ghorbani, M. Curcumin-loaded naturally-based nanofibers as active wound dressing mats: Morphology, drug release, cell proliferation, and cell adhesion studies. New J. Chem. 2020, 44, 10343-10351. [CrossRef]

82. Gruppuso, M.; Turco, G.; Marsich, E.; Porrelli, D. Polymeric wound dressings, an insight into polysaccharide-based electrospun membranes. Appl. Mater. Today 2021, 24, 101148. [CrossRef]

83. Farahani, M.; Shafiee, A. Wound Healing: From Passive to Smart Dressings. Adv. Healthc. Mater. 2021, 10, 2100477. [CrossRef]

84. Sharma, G.; Lee, S.W.; Atanacio, O.; Parvizi, J.; Kim, T.K. In search of the optimal wound dressing material following total hip and knee arthroplasty: A systematic review and meta-analysis. Int. Orthop. 2017, 41, 1295-1305. [CrossRef]

85. Kong, D.; Zhang, Q.; You, J.; Cheng, Y.; Hong, C.; Chen, Z.; Jiang, T.; Hao, T. Adhesion loss mechanism based on carboxymethyl cellulose-filled hydrocolloid dressings in physiological wounds environment. Carbohydr. Polym. 2020, 235, 115953. [CrossRef]

86. Yadav, V.; Mittal, A.; Bansal, P.; Singh, S.K. Regulatory approval process for advanced dressings in India: An overview of rules. J. Wound Care 2019, 28, S32-S42. [CrossRef]

87. Olatunji, O. Classification of Natural Polymers. In Natural Polymers; Olatunji, O., Ed.; Springer: Cham, Switzerland, 2016 ; pp. 1-17.

88. Kulkarni Vishakha, S.; Butte Kishor, D.; Rathod Sudha, S. Natural polymers-A comprehensive review. Int. J. Res. Pharm. Biomed. Sci. 2012, 3, 1597-1613.

89. Alves, T.F.; Morsink, M.; Batain, F.; Chaud, M.V.; Almeida, T.; Fernandes, D.A.; da Silva, C.F.; Souto, E.B.; Severino, P.J.C. Applications of natural, semi-synthetic, and synthetic polymers in cosmetic formulations. Cosmetics 2020, 7, 75. [CrossRef]

90. Bhatia, S. Natural Polymers vs. Synthetic Polymer. In Natural Polymer Drug Delivery Systems; Springer: Cham, Switzerland, 2016; pp. 95-118.

91. Maitz, M.F. Applications of synthetic polymers in clinical medicine. Biosurf. Biotribol. 2015, 1, 161-176. [CrossRef]

92. Gunatillake, P.; Mayadunne, R.; Adhikari, R. Recent developments in biodegradable synthetic polymers. Biotechnol. Annu. Rev. 2006, 12, 301-347.

93. Tavakoli, S.; Klar, A.S. Advanced Hydrogels as Wound Dressings. Biomolecules 2020, 10, 1169. [CrossRef] [PubMed]

94. Brumberg, V.; Astrelina, T.; Malivanova, T.; Samoilov, A. Modern Wound Dressings: Hydrogel Dressings. Biomedicines 2021, 9 , 1235. [CrossRef]

95. Sklenar, Z.; Vitkova, Z.; Herdova, P.; Horackova, K.; Simunkova, V. Formulation and release of alaptide from cellulose-based hydrogels. Acta Vet. Brno 2012, 81, 301-306. [CrossRef]

96. Keogh, S.J.; Nelson, A.; Webster, J.; Jolly, J.; Ullman, A.J.; Chaboyer, W.P. Hydrocolloid dressings for treating pressure ulcers. Cochrane Database Syst. Rev. 2018, 2018, CD010364. [CrossRef]

97. Khorasani, M.T.; Joorabloo, A.; Moghaddam, A.; Shamsi, H.; MansooriMoghadam, Z. Incorporation of ZnO nanoparticles into heparinised polyvinyl alcohol/chitosan hydrogels for wound dressing application. Int. J. Biol. Macromol. 2018, 114, 1203-1215. [CrossRef]

98. Ullah, F.; Othman, M.B.; Javed, F.; Ahmad, Z.; Md Akil, H. Classification, processing and application of hydrogels: A review. Mater. Sci. Eng. C Mater. Biol. Appl. 2015, 57, 414-433. [CrossRef]

99. Ahmed, E.M. Hydrogel: Preparation, characterization, and applications: A review. J. Adv. Res. 2015, 6, 105-121. [CrossRef] [PubMed]

100. Mahinroosta, M.; Jomeh Farsangi, Z.; Allahverdi, A.; Shakoori, Z. Hydrogels as intelligent materials: A brief review of synthesis, properties and applications. Mater. Today Chem. 2018, 8, 42-55. [CrossRef]

101. Vowden, K.; Vowden, P. Wound dressings: Principles and practice. Surgery 2017, 35, 489-494. [CrossRef]

102. Borda, L.J.; Macquhae, F.E.; Kirsner, R.S. Wound Dressings: A Comprehensive Review. Curr. Dermatol. Rep. 2016, 5, 287-297. [CrossRef]

103. Aljghami, M.E.; Saboor, S.; Amini-Nik, S. Emerging Innovative Wound Dressings. Ann. Biomed. Eng. 2019, 47, 659-675. [CrossRef]

104. Meuleneire, F. A vapour-permeable film dressing used on superficial wounds. Br. J. Nurs. 2014, 23, S36-S43. [CrossRef] [PubMed]

105. Samprasit, W.; Chamsai, B.; Settharaksa, S.; Opanasopit, P. Synergistic antibacterial activity of alpha mangostin and resveratrol loaded polymer-based films against bacteria infected wound. J. Drug Deliv. Sci. Technol. 2020, 57, 101629. [CrossRef]

106. Shi, C.Y.; Wang, C.Y.; Liu, H.; Li, Q.J.; Li, R.H.; Zhang, Y.; Liu, Y.Z.; Shao, Y.; Wang, J.C. Selection of Appropriate Wound Dressing for Various Wounds. Front. Bioeng. Biotechnol. 2020, 8, 182. [CrossRef]

107. Lundin, J.G.; McGann, C.L.; Daniels, G.C.; Streifel, B.C.; Wynne, J.H. Hemostatic kaolin-polyurethane foam composites for multifunctional wound dressing applications. Mater. Sci. Eng. C Mater. Biol. Appl. 2017, 79, 702-709. [CrossRef]

108. Dong, R.; Guo, B. Smart wound dressings for wound healing. Nano Today 2021, 41, 101290. [CrossRef]

109. Powers, J.G.; Morton, L.M.; Phillips, T.J. Dressings for chronic wounds. Dermatol. Ther. 2013, 26, 197-206. [CrossRef]

110. Dumville, J.C.; Keogh, S.J.; Liu, Z.; Stubbs, N.; Walker, R.M.; Fortnam, M. Alginate dressings for treating pressure ulcers. Cochrane Database Syst. Rev. 2015, 5, CD011277. [CrossRef]

111. Weller, C.D.; Team, V.; Sussman, G. First-Line Interactive Wound Dressing Update: A Comprehensive Review of the Evidence. Front. Pharmacol. 2020, 11, 155. [CrossRef]

112. Aderibigbe, B.A.; Buyana, B. Alginate in Wound Dressings. Pharmaceutics 2018, 10, 42. [CrossRef]

113. Crabbe-Mann, M.; Tsaoulidis, D.; Parhizkar, M.; Edirisinghe, M. Ethyl cellulose, cellulose acetate and carboxymethyl cellulose microstructures prepared using electrohydrodynamics and green solvents. Cellulose 2018, 25, 1687-1703. [CrossRef] 
114. Liu, K.; Du, H.; Zheng, T.; Liu, H.; Zhang, M.; Zhang, R.; Li, H.; Xie, H.; Zhang, X.; Ma, M.; et al. Recent advances in cellulose and its derivatives for oilfield applications. Carbohydr. Polym. 2021, 259, 117740. [CrossRef] [PubMed]

115. Vlaia, L.; Coneac, G.; Olariu, I.; Vlaia, V.; Lupuleasa, D. Cellulose-Derivatives-Based Hydrogels as Vehicles for Dermal and Transdermal Drug Delivery. In Emerging Concepts in Analysis and Applications of Hydrogels; Majee, S.B., Ed.; IntechOpen: London, UK, 2016; Volume 2, p. 64.

116. Teixeira, M.A.; Paiva, M.C.; Amorim, M.T.P.; Felgueiras, A.H.P. Electrospun Nanocomposites Containing Cellulose and Its Derivatives Modified with Specialized Biomolecules for an Enhanced Wound Healing. Nanomaterials 2020, 10, 557. [CrossRef] [PubMed]

117. Heinze, T. Cellulose: Structure and Properties. In Cellulose Chemistry and Properties: Fibers, Nanocelluloses and Advanced Materials; Rojas, O.J., Ed.; Advances in Polymer Science; Springer: Berlin/Heidelberg, Germany, 2016; Volume 271, pp. 1-52.

118. Miao, J.J.; Pangule, R.C.; Paskaleva, E.E.; Hwang, E.E.; Kane, R.S.; Linhardt, R.J.; Dordick, J.S. Lysostaphin-functionalized cellulose fibers with antistaphylococcal activity for wound healing applications. Biomaterials 2011, 32, 9557-9567. [CrossRef]

119. Wang, Y.G.; Wang, X.J.; Xie, Y.J.; Zhang, K. Functional nanomaterials through esterification of cellulose: A review of chemistry and application. Cellulose 2018, 25, 3703-3731. [CrossRef]

120. Dmour, I.; Taha, M.O. Chapter 2-Natural and semisynthetic polymers in pharmaceutical nanotechnology. In Organic Materials as Smart Nanocarriers for Drug Delivery; Grumezescu, A.M., Ed.; William Andrew Publishing: Amsterdam, The Netherlands, 2018; pp. 35-100.

121. Haldar, D.; Purkait, M.K. Micro and nanocrystalline cellulose derivatives of lignocellulosic biomass: A review on synthesis, applications and advancements. Carbohydr. Polym. 2020, 250, 116937. [CrossRef]

122. Raucci, M.; Alvarez-Perez, M.; Demitri, C.; Giugliano, D.; De Benedictis, V.; Sannino, A.; Ambrosio, L.J. Effect of citric acid crosslinking cellulose-based hydrogels on osteogenic differentiation. J. Biomed. Mater. Res. Part A 2015, 103, 2045-2056. [CrossRef]

123. Yu, J.; Wang, C.P.; Wang, J.F.; Chu, F.X. Synthesis and Characterization of Ethyl Cellulose Based Acrylate. In Proceedings of the 4th International Conference on Manufacturing Science and Engineering (ICMSE 2013), Dalian, China, 30-31 March 2013; pp. 124-130.

124. Fekete, T.; Borsa, J.; Takács, E.; Wojnárovits, L.J.C. Synthesis of cellulose derivative based superabsorbent hydrogels by radiation induced crosslinking. Cellulose 2014, 21, 4157-4165. [CrossRef]

125. Shaghaleh, H.; Xu, X.; Wang, S.F. Current progress in production of biopolymeric materials based on cellulose, cellulose nanofibers, and cellulose derivatives. RSC Adv. 2018, 8, 825-842. [CrossRef]

126. Abdelhak, M.J. A Review: Application of Biopolymers in the Pharmaceutical Formulation. J. Adv. Bio-Pharm. Pharmacovigil. 2019, 1, 15-25. [CrossRef]

127. Goncalves, C.; Favre, C.; Feuardant, P.; Klein, S.; Vaca-Garcia, C.; Cecutti, C.; Thiebaud-Roux, S.; Vedrenne, E. Synthesis of new cellulose ethers using Suzuki-Miyaura reactions. Carbohydr. Polym. 2015, 116, 51-59. [CrossRef] [PubMed]

128. Kabir, S.M.F.; Sikdar, P.P.; Haque, B.; Bhuiyan, M.A.R.; Ali, A.; Islam, M.N. Cellulose-based hydrogel materials: Chemistry, properties and their prospective applications. Prog. Biomater. 2018, 7, 153-174. [CrossRef]

129. Gao, C.Z.; Liu, S.; Edgar, K.J. Regioselective chlorination of cellulose esters by methanesulfonyl chloride. Carbohydr. Polym. 2018, 193, 108-118. [CrossRef]

130. Shokri, J.; Adibki, K. Application of Cellulose and Cellulose Derivatives in Pharmaceutical Industries. In Cellulose-Medical, Pharmaceutical and Electronic Applications; van de Ven, T., Godbout, L., Eds.; IntechOpen: London, UK, 2013.

131. Karlsson, K.; Schuster, E.; Stading, M.; Rigdahl, M. Foaming behavior of water-soluble cellulose derivatives: Hydroxypropyl methylcellulose and ethyl hydroxyethyl cellulose. Cellulose 2015, 22, 2651-2664. [CrossRef]

132. Ambrosio, L.; Demitri, C.; Sannino, A. Superabsorbent cellulose-based hydrogels for biomedical applications. In Biomedical Hydrogels; Rimmer, S., Ed.; Woodhead Publishing: Cambridge, UK, 2011; pp. 25-50.

133. Sannino, A.; Demitri, C.; Madaghiele, M. Biodegradable Cellulose-based Hydrogels: Design and Applications. Materials 2009, 2 , 353-373. [CrossRef]

134. Mao, J.; Li, S.; Huang, J.; Meng, K.; Chen, G.; Lai, Y. Recent Advances of Multifunctional Cellulose-Based Hydrogels. In Cellulose-Based Superabsorbent Hydrogels; Mondal, M., Ed.; Springer: Cham, Switzerland, 2018; pp. 37-64.

135. Kamel, S.; Khattab, T.A. Recent Advances in Cellulose-Based Biosensors for Medical Diagnosis. Biosensors 2020, 10, 67. [CrossRef]

136. Burduşel, A.-C.; Stancu, I.; Marin, I.B.M.Ş.; Chelaru, C.; Serafim, A.; Drăguşin, D.; Kaya, M.G.A.; Coară, G. Development and characterization of collagen-carboxymethylcellulose materials for lenses. In Proceedings of the International Conference on Advanced Materials and Systems (ICAMS), Qingdao, China, 26-27 March 2016; pp. 215-220.

137. Vinklarkova, L.; Masteikova, R.; Vetchy, D.; Dolezel, P.; Bernatoniene, J. Formulation of Novel Layered Sodium Carboxymethylcellulose Film Wound Dressings with Ibuprofen for Alleviating Wound Pain. Biomed. Res. Int. 2015, 2015, 892671. [CrossRef] [PubMed]

138. Zennifer, A.; Senthilvelan, P.; Sethuraman, S.; Sundaramurthi, D. Key advances of carboxymethyl cellulose in tissue engineering \& 3D bioprinting applications. Carbohydr. Polym. 2021, 256, 117561. [CrossRef] [PubMed]

139. Ramli, N.A.; Wong, T.W. Sodium carboxymethylcellulose scaffolds and their physicochemical effects on partial thickness wound healing. Int. J. Pharm. 2011, 403, 73-82. [CrossRef] [PubMed]

140. Fan, L.H.; Peng, M.; Zhou, X.Y.; Wu, H.; Hu, J.; Xie, W.G.; Liu, S.H. Modification of carboxymethyl cellulose grafted with collagen peptide and its antioxidant activity. Carbohydr. Polym. 2014, 112, 32-38. [CrossRef] 
141. Rahman, M.S.; Hasan, M.S.; Nitai, A.S.; Nam, S.; Karmakar, A.K.; Ahsan, M.S.; Shiddiky, M.J.A.; Ahmed, M.B. Recent Developments of Carboxymethyl Cellulose. Polymers 2021, 13, 1345. [CrossRef] [PubMed]

142. Mallakpour, S.; Tukhani, M.; Hussain, C.M. Recent advancements in 3D bioprinting technology of carboxymethyl cellulose-based hydrogels: Utilization in tissue engineering. Adv. Colloid Interface Sci. 2021, 292, 102415. [CrossRef]

143. Udeanu, D.I.; Kaya, M.G.A.; Ghica, M.V.; Marin, S.; Marin, M.M.; Kaya, D.A.; Popa, L.; Dinu-Pirvu, C. Anti-inflammatory drug-loaded biopolymeric spongious matrices with therapeutic perspectives in burns treatment. Farmacia 2018, 66, 783-790. [CrossRef]

144. Miraftab, M.; Qiao, Q.; Kennedy, J.F.; Knill, C.J.; Groocock, M.R. Advanced Wound-care Materials: Ultra High Absorbing Fibres made from Alginates Containing Branan Ferulate and Carboxymethyl Cellulose. J. Text. Inst. 2010, 95, 341-348. [CrossRef]

145. Alavi, M.; Nokhodchi, A. Antimicrobial and Wound Treatment Aspects of Micro- and Nanoformulations of Carboxymethyl, Dialdehyde, and TEMPO-Oxidized Derivatives of Cellulose: Recent Advances. Macromol. Biosci. 2020, 20, 1900362. [CrossRef]

146. Wong, T.W.; Ramli, N.A. Carboxymethylcellulose film for bacterial wound infection control and healing. Carbohydr. Polym. 2014, 112, 367-375. [CrossRef]

147. Ali, M.; Khan, N.R.; Basit, H.M.; Mahmood, S. Physico-chemical based mechanistic insight into surfactant modulated sodium Carboxymethylcellulose film for skin tissue regeneration applications. J. Polym. Res. 2019, 27, 20. [CrossRef]

148. Krizova, H.; Wiener, J. Development of carboxymethyl cellulose/polyphenols gels for textile applications. Autex Res. J. 2013, 13, 33-36. [CrossRef]

149. Fukuyama, Y.; Maruo, T.; Nishiyama, Y.; Nemoto, Y.; Murayama, K.; Kayanuma, H.; Kawarai, S. Application of a novel carboxymethyl cellulose-based Mohs sol-gel on malignant wounds in three dogs. J. Vet. Med. Sci. 2021, 83, 385-389. [CrossRef]

150. Lee, S.; Park, Y.H.; Ki, C.S. Fabrication of PEG-carboxymethylcellulose hydrogel by thiol-norbornene photo-click chemistry. Int. J. Biol. Macromol. 2016, 83, 1-8. [CrossRef] [PubMed]

151. Liu, Y.; Chen, Y.; Zhao, Y.; Tong, Z.R.; Chen, S.S. Superabsorbent Sponge and Membrane Prepared by Polyelectrolyte Complexation of Carboxymethyl Cellulose/Hydroxyethyl Cellulose-Al ${ }^{3+}$. BioResources 2015, 10, 6479-6495. [CrossRef]

152. Hu, D.; Qiang, T.; Wang, L. Quaternized chitosan/polyvinyl alcohol/sodium carboxymethylcellulose blend film for potential wound dressing application. Wound Med. 2017, 16, 15-21. [CrossRef]

153. Nargesi Khoramabadi, H.; Arefian, M.; Hojjati, M.; Tajzad, I.; Mokhtarzade, A.; Mazhar, M.; Jamavari, A. A review of Polyvinyl alcohol/Carboxymethyl cellulose (PVA/CMC) composites for various applications. J. Compos. Compd. 2020, 2, 69-76. [CrossRef]

154. Lim, S.J.; Lee, J.H.; Piao, M.G.; Lee, M.K.; Oh, D.H.; Hwang, D.H.; Quan, Q.Z.; Yong, C.S.; Choi, H.G. Effect of sodium carboxymethylcellulose and fucidic acid on the gel characterization of polyvinylalcohol-based wound dressing. Arch. Pharm. Res. 2010, 33, 1073-1081. [CrossRef]

155. Zhang, K.; Wang, Y.N.; Wei, Q.H.; Li, X.P.; Guo, Y.; Zhang, S. Design and Fabrication of Sodium Alginate/Carboxymethyl Cellulose Sodium Blend Hydrogel for Artificial Skin. Gels 2021, 7, 115. [CrossRef]

156. Shin, J.Y.; Lee, D.Y.; Kim, B.Y.; Yoon, J.I. Effect of polyethylene glycol molecular weight on cell growth behavior of polyvinyl alcohol/carboxymethyl cellulose/polyethylene glycol hydrogel. J. Appl. Polym. Sci. 2020, 137, 49568. [CrossRef]

157. Fan, L.H.; Zhou, X.Y.; Wu, P.H.; Xie, W.G.; Zheng, H.; Tan, W.; Liu, S.H.; Li, Q.Y. Preparation of carboxymethyl cellulose sulfates and its application as anticoagulant and wound dressing. Int. J. Biol. Macromol. 2014, 66, 245-253. [CrossRef] [PubMed]

158. Lee, J.Y.; Im, J.N.; Kim, T.H.; Chung, D.J.; Doh, S.J. Structure and Liquid Handling Properties of Water-insoluble Carboxymethyl Cellulose Foam. Fiber. Polym. 2015, 16, 726-734. [CrossRef]

159. Marchianti, A.C.N.; Sakinah, E.N.; Elfiah, U.; Putri, N.K.S.; Wahyuliswari, D.I.; Maulana, M.; Ulfa, E.U. Gel formulations of Merremia mammosa (Lour.) accelerated wound healing of the wound in diabetic rats. J. Tradit. Complement. Med. 2021, 11, 38-45. [CrossRef] [PubMed]

160. Park, J.S.; An, S.J.; Jeong, S.I.; Gwon, H.J.; Lim, Y.M.; Nho, Y.C. Chestnut Honey Impregnated Carboxymethyl Cellulose Hydrogel for Diabetic Ulcer Healing. Polymers 2017, 9, 248. [CrossRef] [PubMed]

161. Ali, N.H.; Amin, M.; Ng, S.F. Sodium carboxymethyl cellulose hydrogels containing reduced graphene oxide (rGO) as a functional antibiofilm wound dressing. J. Biomater. Sci.-Polym. Ed. 2019, 30, 629-645. [CrossRef]

162. Ng, S.F.; Jumaat, N. Carboxymethyl cellulose wafers containing antimicrobials: A modern drug delivery system for wound infections. Eur. J. Pharm. Sci. 2014, 51, 173-179. [CrossRef] [PubMed]

163. Javanbakht, S.; Nabi, M.; Shadi, M.; Amini, M.M.; Shaabani, A. Carboxymethyl cellulose/tetracycline@UiO-66 nanocomposite hydrogel films as a potential antibacterial wound dressing. Int. J. Biol. Macromol. 2021, 188, 811-819. [CrossRef]

164. Rakhshaei, R.; Namazi, H. A potential bioactive wound dressing based on carboxymethyl cellulose/ZnO impregnated MCM-41 nanocomposite hydrogel. Mater. Sci. Eng. C 2017, 73, 456-464. [CrossRef]

165. Vinklarkova, L.; Masteikova, R.; Foltynova, G.; Muselik, J.; Pavlokova, S.; Bernatoniene, J.; Vetchy, D. Film wound dressing with local anesthetic based on insoluble carboxymethycellulose matrix. J. Appl. Biomed. 2017, 15, 313-320. [CrossRef]

166. Shi, D.D.; Wang, F.J.; Lan, T.; Zhang, Y.H.; Shao, Z.Q. Convenient fabrication of carboxymethyl cellulose electrospun nanofibers functionalized with silver nanoparticles. Cellulose 2016, 23, 1899-1909. [CrossRef]

167. Tu, C.; Zhang, R.D.; Yan, C.; Guo, Y.; Cui, L. A pH indicating carboxymethyl cellulose/chitosan sponge for visual monitoring of wound healing. Cellulose 2019, 26, 4541-4552. [CrossRef]

168. Bang, S.; Ko, Y.G.; Kim, W.I.; Cho, D.; Park, W.H.; Kwon, O.H. Preventing postoperative tissue adhesion using injectable carboxymethyl cellulose-pullulan hydrogels. Int. J. Biol. Macromol. 2017, 105, 886-893. [CrossRef] 
169. Siritientong, T.; Aramwit, P. Characteristics of carboxymethyl cellulose/sericin hydrogels and the influence of molecular weight of carboxymethyl cellulose. Macromol. Res. 2015, 23, 861-866. [CrossRef]

170. Wang, P.; He, H.W.; Cai, R.; Tao, G.; Yang, M.R.; Zuo, H.; Umar, A.; Wang, Y.J. Cross-linking of dialdehyde carboxymethyl cellulose with silk sericin to reinforce sericin film for potential biomedical application. Carbohydr. Polym. 2019, $212,403-411$. [CrossRef]

171. Wang, X.; Qi, J.; Zhang, W.; Pu, Y.; Yang, R.; Wang, P.; Liu, S.; Tan, X.; Chi, B. 3D-printed antioxidant antibacterial carboxymethyl cellulose / $\varepsilon$-polylysine hydrogel promoted skin wound repair. Int. J. Biol. Macromol. 2021, 187, 91-104. [CrossRef]

172. Ninan, N.; Muthiah, M.; Park, I.K.; Kalarikkal, N.; Elain, A.; Wong, T.W.; Thomas, S.; Grohens, Y. Wound healing analysis of pectin/carboxymethyl cellulose/microfibrillated cellulose based composite scaffolds. Mater. Lett. 2014, 132, 34-37. [CrossRef]

173. Jantrawut, P.; Bunrueangtha, J.; Suerthong, J.; Kantrong, N. Fabrication and Characterization of Low Methoxyl Pectin/Gelatin/ Carboxymethyl Cellulose Absorbent Hydrogel Film for Wound Dressing Applications. Materials 2019, 12, 1628. [CrossRef]

174. Liang, M.; Chen, Z.M.; Wang, F.P.; Liu, L.; Wei, R.N.; Zhang, M. Preparation of self-regulating/anti-adhesive hydrogels and their ability to promote healing in burn wounds. J. Biomed. Mater. Res. Part B 2019, 107, 1471-1482. [CrossRef]

175. Li, D.F.; Ye, Y.X.; Li, D.R.; Li, X.Y.; Mu, C.D. Biological properties of dialdehyde carboxymethyl cellulose crosslinked gelatin-PEG composite hydrogel fibers for wound dressings. Carbohydr. Polym. 2016, 137, 508-514. [CrossRef]

176. Doh, S.J.; Lee, J.Y.; Lim, D.Y.; Im, J.N. Manufacturing and analyses of wet-laid nonwoven consisting of carboxymethyl cellulose fibers. Fibers Polym. 2013, 14, 2176-2184. [CrossRef]

177. Nitipir, C.; Marin, S.; Marin, M.M.; Kaya, M.A.; Ghica, M.V.; Mederle, N. Hybrid Collagen-NaCMC Matrices Loaded with Mefenamic Acid for Wound Healing. Rev. Chim. 2017, 68, 2605-2609. [CrossRef]

178. Leau, S.A.; Marin, S.; Coara, G.; Albu, L.; Constantinescu, R.R.; Kaya, M.A.; Neacsu, I.A. Study of wound-dressing materials based on collagen, sodium carboxymethylcellulose and silver nanoparticles used for their antibacterial activity in burn injuries. In Proceedings of the 7th International Conference on Advanced Materials and Systems, Bucharest, Romania, 18-20 October 2018; pp. 123-128.

179. Maver, T.; Kurecic, M.; Pivec, T.; Maver, U.; Gradisnik, L.; Gasparic, P.; Kaker, B.; Bratusa, A.; Hribernik, S.; Kleinschek, K.S. Needleless electrospun carboxymethyl cellulose/polyethylene oxide mats with medicinal plant extracts for advanced wound care applications. Cellulose 2020, 27, 4487-4508. [CrossRef]

180. Maver, T.; Kurecic, M.; Smrke, D.M.; Kleinschek, K.S.; Maver, U. Electrospun nanofibrous CMC/PEO as a part of an effective pain-relieving wound dressing. J. Sol-Gel Sci. Technol. 2016, 79, 475-486. [CrossRef]

181. Wang, F.J.; Shi, D.D.; Lan, T.; Zhang, Y.H.; Shao, Z.Q. One-step preparation of carboxymethyl cellulose/polyoxyethylene nanofiber mats containing silver nanoparticles. Integr. Ferroelectr. 2016, 169, 50-57. [CrossRef]

182. Oliveira, R.N.; Moreira, A.P.D.; Thire, R.; Quilty, B.; Passos, T.M.; Simon, P.; Mancini, M.C.; McGuinness, G.B. Absorbent Polyvinyl Alcohol-Sodium Carboxymethyl Cellulose Hydrogels for Propolis Delivery in Wound Healing Applications. Polym. Eng. Sci. 2017, 57, 1224-1233. [CrossRef]

183. Joorabloo, A.; Khorasani, M.T.; Adeli, H.; Mansoori-Moghadam, Z.; Moghaddam, A. Fabrication of heparinized nano $\mathrm{ZnO} /$ poly(vinylalcohol)/carboxymethyl cellulose bionanocomposite hydrogels using artificial neural network for wound dressing application. J. Ind. Eng. Chem. 2019, 70, 253-263. [CrossRef]

184. Pagano, C.; Calarco, P.; Di Michele, A.; Ceccarini, M.R.; Beccari, T.; Primavilla, S.; Scuota, S.; Marmottini, F.; Ramella, D.; Ricci, M.; et al Development of sodium carboxymethyl cellulose based polymeric microparticles for in situ hydrogel wound dressing formation. Int. J. Pharm. 2021, 602, 120606. [CrossRef]

185. Maver, T.; Hribernik, S.; Mohan, T.; Smrke, D.M.; Maver, U.; Stana-Kleinschek, K. Functional wound dressing materials with highly tunable drug release properties. RSC Adv. 2015, 5, 77873-77884. [CrossRef]

186. Trevisol, T.C.; Scartazzini, L.; Valerio, A.; de Souza, S.; Bierhalz, A.C.K.; Valle, J.A.B. Diclofenac release from alginate/carboxymethyl cellulose mono and bilayer films for wound dressing applications. Cellulose 2020, 27, 6629-6642. [CrossRef]

187. Birsan, M.; Bibire, N.; Vieriu, M.; Panainte, A.D.; Cojocaru, I. Influence of Hydroxypropyl Methylcellulose on Flowing and Swelling Parameters in Biomucoadhesive Tablets with Miconazole Nitrate. Rev. Chim. 2017, 68, 2346-2349. [CrossRef]

188. Zhang, L.; Lu, Y.Q.; Qian, J.Y.; Yue, L.N.; Li, Q.; Xiao, L.X.; Ding, X.L.; Guan, C.R. Microstructures, physical and sustained antioxidant properties of hydroxypropyl methylcellulose based microporous photophobic films. Int. J. Biol. Macromol. 2020, 152, 1002-1009. [CrossRef]

189. Rao, B.L.; Shivananda, C.S.; Shetty, G.R.; Harish, K.V.; Madhukumar, R.; Sangappa, Y. Influence of UV Irradiation on Hydroxypropyl Methylcellulose Polymer Films. In Proceedings of the 2nd International Conference on Condensed Matter and Applied Physics (ICC), Bikaner, India, 24-25 November 2017.

190. Jayaramudu, T.; Varaprasad, K.; Pyarasani, R.D.; Reddy, K.K.; Akbari-Fakhrabadi, A.; Carrasco-Sanchez, V.; Amalraj, J. Hydroxypropyl methylcellulose-copper nanoparticle and its nanocomposite hydrogel films for antibacterial application. Carbohydr. Polym. 2021, 254, 117302. [CrossRef]

191. Akinosho, H.; Hawkins, S.; Wicker, L. Hydroxypropyl methylcellulose substituent analysis and rheological properties. Carbohydr. Polym. 2013, 98, 276-281. [CrossRef]

192. Tundisi, L.L.; Mostaco, G.B.; Carricondo, P.C.; Petri, D.F.S. Hydroxypropyl methylcellulose: Physicochemical properties and ocular drug delivery formulations. Eur. J. Pharm. Sci. 2021, 159, 105736. [CrossRef] 
193. Kamel, R.; El-batanony, R.; Salama, A. Pioglitazone-loaded three-dimensional composite polymeric scaffolds: A proof of concept study in wounded diabetic rats. Int. J. Pharm. 2019, 570, 118667. [CrossRef]

194. Wang, T.; Chen, L.M.; Shen, T.T.; Wu, D.Y. Preparation and properties of a novel thermo-sensitive hydrogel based on chitosan/hydroxypropyl methylcellulose/glycerol. Int. J. Biol. Macromol. 2016, 93, 775-782. [CrossRef]

195. Bonetti, L.; De Nardo, L.; Fare, S. Thermo-Responsive Methylcellulose Hydrogels: From Design to Applications as Smart Biomaterials. Tissue Eng. Part B Rev. 2020, 27, 486-513. [CrossRef]

196. Siepmann, J.; Peppas, N.A. Modeling of drug release from delivery systems based on hydroxypropyl methylcellulose (HPMC). Adv. Drug Deliv. Rev. 2012, 64, 163-174. [CrossRef]

197. Kumari, S.; Harjai, K.; Chhibber, S. Topical treatment of Klebsiella pneumoniae B5055 induced burn wound infection in mice using natural products. J. Infect. Dev. Ctries. 2010, 4, 367-377. [CrossRef]

198. Ghadermazi, R.; Hamdipour, S.; Sadeghi, K.; Ghadermazi, R.; Asl, A.K. Effect of various additives on the properties of the films and coatings derived from hydroxypropyl methylcellulose-A review. Food Sci. Nutr. 2019, 7, 3363-3377. [CrossRef]

199. Liu, H.W.; Chaw, J.R.; Shih, Y.C.; Huang, C.C. Designed hydrocolloid interpenetrating polymeric networks for clinical applications of novel drug-carrying matrix systems using Tris (6-isocyanatohexyl) isocyanurate and hydroxypropylmethylcellulose. Bio-Med. Mater. Eng. 2014, 24, 2065-2072. [CrossRef]

200. Song, J.; Feng, H.; Wu, M.; Chen, L.; Xia, W.; Zhang, W. Preparation and characterization of arginine-modified chitosan/hydroxypropyl methylcellose antibacterial film. Int. J. Biol. Macromol. 2020, 145, 750-758. [CrossRef]

201. Yin, J.; Fang, Y.; Xu, L.; Ahmed, A. High-throughput fabrication of silk fibroin/hydroxypropyl methylcellulose (SF/HPMC) nanofibrous scaffolds for skin tissue engineering. Int. J. Biol. Macromol. 2021, 183, 1210-1221. [CrossRef]

202. Uslu, I.; Aytimur, A.; Serincay, H. Preparation of PVA/PAA/PEG/PVP Nanofibers with HPMC and Aloe Vera. Curr. Nanosci. 2013, 9, 489-493. [CrossRef]

203. Zhang, L.; Yue, L.N.; Qian, J.Y.; Ding, X.L. Effect of Curdlan on the Rheological Properties of Hydroxypropyl Methylcellulose. Foods 2021, 10, 34. [CrossRef]

204. Liu, X.X.; Ji, Z.L.; Peng, W.W.; Chen, M.; Yu, L.; Zhu, F. Chemical mapping analysis of compatibility in gelatin and hydroxypropyl methylcellulose blend films. Food Hydrocoll. 2020, 104, 105734. [CrossRef]

205. Wang, Y.F.; Yu, L.; Xie, F.W.; Li, S.; Sun, Q.J.; Liu, H.S.; Chen, L. On the investigation of thermal/cooling-gel biphasic systems based on hydroxypropyl methylcellulose and hydroxypropyl starch. Ind. Crop. Prod. 2018, 124, 418-428. [CrossRef]

206. Ding, C.C.; Zhang, M.; Li, G.Y. Rheological Properties of Collagen/Hydroxypropyl Methylcellulose (COL/HPMC) Blended Solutions. J. Appl. Polym. Sci. 2014, 131, 40042. [CrossRef]

207. Shao, X.R.; Sun, H.T.; Zhou, R.; Zhao, B.B.; Shi, J.F.; Jiang, R.P.; Dong, Y. Effect of bovine bone collagen and nano-TiO 2 on the properties of hydroxypropyl methylcellulose films. Int. J. Biol. Macromol. 2020, 158, 937-944. [CrossRef]

208. Barros, S.C.; da Silva, A.A.; Costa, D.B.; Costa, C.M.; Lanceros-Mendez, S.; Maciavello, M.N.T.; Ribelles, J.L.G.; Sentanin, F.; Pawlicka, A.; Silva, M.M. Thermal-mechanical behaviour of chitosan-cellulose derivative thermoreversible hydrogel films. Cellulose 2015, 22, 1911-1929. [CrossRef]

209. Ngwabebhoh, F.A.; Zandraa, O.; Patwa, R.; Saha, N.; Capakova, Z.; Saha, P. Self-crosslinked chitosan/dialdehyde xanthan gum blended hypromellose hydrogel for the controlled delivery of ampicillin, minocycline and rifampicin. Int. J. Biol. Macromol. 2021, 167, 1468-1478. [CrossRef]

210. da Silva, M.N.; Fonseca, J.D.; Feldhaus, H.K.; Soares, L.S.; Valencia, G.A.; de Campos, C.E.M.; Di Luccio, M.; Monteiro, A.R. Physical and morphological properties of hydroxypropyl methylcellulose films with curcumin polymorphs. Food Hydrocoll. 2019, 97, 105217. [CrossRef]

211. da Silva, J.B.; Cook, M.T.; Bruschi, M.L. Thermoresponsive systems composed of poloxamer 407 and HPMC or NaCMC: Mechanical, rheological and sol-gel transition analysis. Carbohydr. Polym. 2020, 240, 116268. [CrossRef]

212. Dong, T.; Mi, R.X.; Wu, M.; Zhong, N.P.; Zhao, X.; Chen, X.; Shao, Z.Z. The regenerated silk fibroin hydrogel with designed architecture bioprinted by its microhydrogel. J. Mat. Chem. B 2019, 7, 4328-4337. [CrossRef]

213. Tekko, I.A.; Chen, G.Y.; Dominguez-Robles, J.; Thakur, R.R.S.; Hamdan, I.M.N.; Vora, L.; Larraneta, E.; McElnay, J.C.; McCarthy, H.O.; Rooney, M.; et al. Development and characterisation of novel poly (vinyl alcohol)/poly (vinyl pyrrolidone)-based hydrogelforming microneedle arrays for enhanced and sustained transdermal delivery of methotrexate. Int. J. Pharm. 2020, 586, 119580. [CrossRef]

214. Chen, Y.C.; Chen, Y.H. Thermo and pH-responsive methylcellulose and hydroxypropyl methylcellulose hydrogels containing $\mathrm{K}_{2} \mathrm{SO}_{4}$ for water retention and a controlled-release water-soluble fertilizer. Sci. Total Environ. 2019, 655, 958-967. [CrossRef]

215. Sun, G.H.; Liang, T.Q.; Tan, W.Y.; Wang, L.J. Rheological behaviors and physical properties of plasticized hydrogel films developed from kappa-carrageenan incorporating hydroxypropyl methylcellulose. Food Hydrocoll. 2018, 85, 61-68. [CrossRef]

216. Hu, M.; Yang, J.L.; Xu, J.H. Structural and biological investigation of chitosan/hyaluronic acid with silanized-hydroxypropyl methylcellulose as an injectable reinforced interpenetrating network hydrogel for cartilage tissue engineering. Drug Deliv. 2021, 28, 607-619. [CrossRef]

217. Bagheri, M.; Shokoohinia, Y.; Pourmanouchehri, Z.; Jalilian, F.; Khaledian, S.; Mirzaie, S.; Behbood, L. Formulation and evaluation of the novel herbal antibacterial gel to the treatment of cutaneous burn infections. J. Rep. Pharm. Sci. 2021, 10, 93-100. [CrossRef]

218. Wu, Y.C.; Wu, G.X.; Huang, H.H.; Kuo, S.M. Liposome-encapsulated farnesol accelerated tissue repair in third-degree burns on a rat model. Burns 2019, 45, 1139-1151. [CrossRef] 
219. Chang, R.Y.K.; Morales, S.; Okamoto, Y.; Chan, H.-K. Topical application of bacteriophages for treatment of wound infections. Transl. Res. 2020, 220, 153-166. [CrossRef]

220. Saddik, M.S.; Alsharif, F.M.; El-Mokhtar, M.A.; Al-Hakkani, M.F.; El-Mahdy, M.M.; Farghaly, H.S.; Abou-Taleb, H.A. Biosynthesis, Characterization, and Wound-Healing Activity of Phenytoin-Loaded Copper Nanoparticles. AAPS PharmSciTech 2020, 21, 175. [CrossRef]

221. Zakaria, A.S.; Afifi, S.A.; Elkhodairy, K.A. Newly Developed Topical Cefotaxime Sodium Hydrogels: Antibacterial Activity and In Vivo Evaluation. BioMed Res. Int. 2016, 2016, 6525163. [CrossRef]

222. Febriyenti; Noor, A.M.; Baie, S.B. Mechanical properties and water vapour permeability of film from haruan (Channa striatus) and fusidic acid spray for wound dressing and wound healing. Pak. J. Pharm. Sci. 2010, 23, 155-159.

223. Huang, T.W.; Lu, H.T.; Ho, Y.C.; Lu, K.Y.; Wang, P.; Mi, F.L. A smart and active film with tunable drug release and color change abilities for detection and inhibition of bacterial growth. Mater. Sci. Eng. C Mater. Biol. Appl. 2021, 118, 111396. [CrossRef]

224. Claudio-Rizo, J.A.; Hernandez-Hernandez, N.G.; Cano-Salazar, L.F.; Flores-Guia, T.E.; de la Cruz-Duran, F.N.; Cabrera-Munguia, D.A.; Becerra-Rodriguez, J.J. Novel semi-interpenetrated networks based on collagen-polyurethane-polysaccharides in hydrogel state for biomedical applications. J. Appl. Polym. Sci. 2021, 138, 49739. [CrossRef]

225. Jiang, Q.; Zhou, W.; Wang, J.; Tang, R.P.; Zhang, D.; Wang, X. Hypromellose succinate-crosslinked chitosan hydrogel films for potential wound dressing. Int. J. Biol. Macromol. 2016, 91, 85-91. [CrossRef]

226. Chen, C.P.; Hsieh, C.M.; Tsai, T.; Yang, J.C.; Chen, C.T. Optimization and Evaluation of a Chitosan/Hydroxypropyl Methylcellulose Hydrogel Containing Toluidine Blue O for Antimicrobial Photodynamic Inactivation. Int. J. Mol. Sci. 2015, 16, 20859-20872. [CrossRef]

227. Anuroop, U.P.; Nair, S.S.; Chacko, A.J. Development and evaluation of medicated biodegradable film for wounds and burns. Int. J. Pharm.l Sci. Res. 2019, 10, 5664-5672. [CrossRef]

228. Pathan, I.B.; Munde, S.J.; Shelke, S.; Ambekar, W.; Setty, C.M. Curcumin loaded fish scale collagen-HPMC nanogel for wound healing application: Ex-vivo and In-vivo evaluation. Int. J. Polym. Mater. Polym. Biomat. 2019, 68, 165-174. [CrossRef]

229. Qiu, Y.M.; Sun, X.X.; Lin, X.L.; Yi, W.Y.; Jiang, J.Y. An injectable metal nanoparticle containing cellulose derivative-based hydrogels: Evaluation of antibacterial and in vitro-vivo wound healing activity in children with burn injuries. Int. Wound J. 2021, 13, 13664. [CrossRef] [PubMed]

230. Bianchi, S.E.; Machado, B.E.K.; da Silva, M.G.C.; da Silva, M.M.A.; Dal Bosco, L.; Marques, M.S.; Horn, A.P.; Persich, L.; Geller, F.C.; Argenta, D.; et al. Coumestrol/hydroxypropyl-beta-cyclodextrin association incorporated in hydroxypropyl methylcellulose hydrogel exhibits wound healing effect: In vitro and in vivo study. Eur. J. Pharm. Sci. 2018, 119, 179-188. [CrossRef] [PubMed]

231. Pinho, E.; Henriques, M.; Soares, G. Cyclodextrin/cellulose hydrogel with gallic acid to prevent wound infection. Cellulose 2014, 21, 4519-4530. [CrossRef]

232. Uslu, I.; Aytimur, A. Production and characterization of poly(vinyl alcohol)/poly(vinylpyrrolidone) iodine/poly(ethylene glycol) electrospun fibers with (hydroxypropyl)methyl cellulose and aloe vera as promising material for wound dressing. J. Appl. Polym. Sci. 2012, 124, 3520-3524. [CrossRef]

233. Lakshmi, P.K.; Thangellapalli, N.; Chennuri, A.; Prasanthi, D.; Veeresh, B. Wound healing activity of topical lawsone gel on rat model. Int. J. Pharm. Sci. Res. 2017, 8, 3162-3169. [CrossRef]

234. Abraham, S.; Harsha, G.G.S.; Desai, K.; Furtado, S.; Srinivasan, B. Nano Calcium Oxide Incorporated Hydrocolloid Dressings for Wound Care. J. Pharm. Innov. 2020, 12. [CrossRef]

235. Kondaveeti, S.; Damato, T.C.; Carmona-Ribeiro, A.M.; Sierakowski, M.R.; Petri, D.F.S. Sustainable hydroxypropyl methylcellulose/xyloglucan/gentamicin films with antimicrobial properties. Carbohydr. Polym. 2017, 165, 285-293. [CrossRef]

236. Prabu, D.; Majdalawieh, A.F.; Abu-Yousef, I.A.; Inbasekaran, K.; Balasubramaniam, T.; Nallaperumal, N.; Gunasekar, C.J Preparation and characterization of gatifloxacin-loaded sodium alginate hydrogel membranes supplemented with hydroxypropyl methylcellulose and hydroxypropyl cellulose polymers for wound dressing. Int. J. Pharm. Investig. 2016, 6, 86-95. [CrossRef]

237. Arafa, M.G.; El-Kased, R.F.; Elmazar, M.M. Thermoresponsive gels containing gold nanoparticles as smart antibacterial and wound healing agents. Sci. Rep. 2018, 8, 13674. [CrossRef]

238. Wu, Z.; Hong, Y.L. Combination of the Silver-Ethylene Interaction and 3D Printing to Develop Antibacterial Superporous Hydrogels for Wound Management. ACS Appl. Mater. Interfaces 2019, 11, 33734-33747. [CrossRef]

239. Grip, J.; Engstad, R.E.; Skjaeveland, I.; Skalko-Basnet, N.; Isaksson, J.; Basnet, P.; Holsaeter, A.M. Beta-glucan-loaded nanofiber dressing improves wound healing in diabetic mice. Eur. J. Pharm. Sci. 2018, 121, 269-280. [CrossRef] [PubMed]

240. Bilbao-Sainz, C.; Chiou, B.-S.; Valenzuela-Medina, D.; Du, W.-X.; Gregorski, K.S.; Williams, T.G.; Wood, D.F.; Glenn, G.M.; Orts, W.J. Solution blow spun poly(lactic acid)/hydroxypropyl methylcellulose nanofibers with antimicrobial properties. Eur. Polym. J. 2014, 54, 1-10. [CrossRef]

241. Namuiriyachote, N.; Lipipun, V.; Althhatuattananglzul, Y.; Charoonrut, P.; Ritthidej, G.C. Development of polyurethane foam dressing containing silver and asiaticoside for healing of dermal wound. Asian J. Pharm. Sci. 2019, 14, 63-77. [CrossRef] [PubMed]

242. Das, S.; De, A.; Das, B.; Mukherjee, B.; Samanta, A. Development of gum odina-gelatin based antimicrobial loaded biodegradable spongy scaffold: A promising wound care tool. J. Appl. Polym. Sci. 2021, 138, 50057. [CrossRef]

243. Wikene, K.O.; Hegge, A.B.; Bruzell, E.; Tonnesen, H.H. Formulation and characterization of lyophilized curcumin solid dispersions for antimicrobial photodynamic therapy (aPDT): Studies on curcumin and curcuminoids LII. Drug Dev. Ind. Pharm. 2015, 41, 969-977. [CrossRef] 
244. Pinho, E.; Machado, S.; Soares, G. Smart Hydrogel for the pH-Selective Drug Delivery of Antimicrobial Compounds. In Proceedings of the 24th Polymer-Networks-Group Conference/82nd Prague Meeting on Macromolecules, Prague, Czech Republic, 17-21 June 2018.

245. Oliveira, D.M.L.; Rezende, P.S.; Barbosa, T.C.; Andrade, L.N.; Bani, C.; Tavares, D.S.; da Silva, C.F.; Chaud, M.V.; Padilha, F.; Cano, A.; et al. Double membrane based on lidocaine-coated polymyxin-alginate nanoparticles for wound healing: In vitro characterization and in vivo tissue repair. Int. J. Pharm. 2020, 591, 120001. [CrossRef]

246. Agubata, C.O.; Okereke, C.; Nzekwe, I.T.; Onoja, R.I.; Obitte, N.C. Development and evaluation of wound healing hydrogels based on a quinolone, hydroxypropyl methylcellulose and biodegradable microfibres. Eur. J. Pharm. Sci. 2016, 89, 1-10. [CrossRef]

247. Pišlová, M.; Kolářová, K.; Vokatá, B.; Brož, A.; Ulbrich, P.; Bačáková, L.; Kolská, Z.; Švorčík, V. A new way to prepare gold nanoparticles by sputtering-Sterilization, stability and other properties. Mater. Sci. Eng. C 2020, 115, 111087. [CrossRef]

248. Schuhladen, K.; Mukoo, P.; Liverani, L.; Nescakova, Z.; Boccaccini, A.R. Manuka honey and bioactive glass impart methylcellulose foams with antibacterial effects for wound-healing applications. Biomed. Mater. 2020, 15, 065002. [CrossRef]

249. Fattahpour, S.; Shamanian, M.; Tavakoli, N.; Fathi, M.; Sadeghi-Aliabadi, H.; Sheykhi, S.R.; Fesharaki, M.; Fattahpour, S. An injectable carboxymethyl chitosan-methylcellulose-pluronic hydrogel for the encapsulation of meloxicam loaded nanoparticles. Int. J. Biol. Macromol. 2020, 151, 220-229. [CrossRef]

250. Kar, A.K.; Shil, A.; Kar, B.; Dey, S. Formulation development and statistical optimization of zingiberol incorporated sodium alginate-methyl cellulose blend microspheres. Int. J. Biol. Macromol. 2020, 162, 1578-1586. [CrossRef] [PubMed]

251. Coughlin, M.L.; Liberman, L.; Ertem, S.P.; Edmund, J.; Bates, F.S.; Lodge, T.P. Methyl cellulose solutions and gels: Fibril formation and gelation properties. Prog. Polym. Sci. 2021, 112, 101324. [CrossRef]

252. Sangfai, T.; Tantishaiyakul, V.; Hirun, N.; Li, L. Microphase Separation and Gelation of Methylcellulose in the Presence of Gallic Acid and $\mathrm{NaCl}$ as an In Situ Gel-Forming Drug Delivery System. AAPS PharmSciTech 2017, 18, 605-616. [CrossRef] [PubMed]

253. El-Naggar, A.W.M.; Senna, M.M.; Mostafa, T.A.; Helal, R.H. Radiation synthesis and drug delivery properties of interpenetrating networks (IPNs) based on poly(vinyl alcohol)/methylcellulose blend hydrogels. Int. J. Biol. Macromol. 2017, 102, 1045-1051. [CrossRef] [PubMed]

254. Sharma, K.; Bullock, A.; Ralston, D.; MacNeil, S. Development of a one-step approach for the reconstruction of full thickness skin defects using minced split thickness skin grafts and biodegradable synthetic scaffolds as a dermal substitute. Burns 2014, 40, 957-965. [CrossRef] [PubMed]

255. Synytsya, A.; Grafova, M.; Slepicka, P.; Gedeon, O.; Synytsya, A. Modification of chitosan-methylcellulose composite films with meso-tetrakis(4-sulfonatophenyl)porphyrin. Biomacromolecules 2012, 13, 489-498. [CrossRef]

256. Abu, N.; Kasim, S.H.; Hisham, S.F.; Shamsudin, S.; Noorsal, K.; Mastor, A. Effect of Methylcellulose on the Hydrophilicity of Chitosan 3D-Porous Scaffold. Adv. Mater. Res. 2016, 1133, 55-59. [CrossRef]

257. Tan, W.; Zhang, J.; Zhao, X.; Li, Q.; Dong, F.; Guo, Z. Preparation and physicochemical properties of antioxidant chitosan ascorbate/methylcellulose composite films. Int. J. Biol. Macromol. 2020, 146, 53-61. [CrossRef]

258. Negim, E.S.M.; Nurpeissova, Z.A.; Mangazbayeva, R.A.; Khatib, J.M.; Williams, C.; Mun, G.A. Effect of pH on the physicomechanical properties and miscibility of methyl cellulose/poly(acrylic acid) blends. Carbohydr. Polym. 2014, 101, 415-422. [CrossRef]

259. Varshosaz, J.; Sajadi-Javan, Z.S.; Kouhi, M.; Mirian, M. Effect of bassorin (derived from gum tragacanth) and halloysite nanotubes on physicochemical properties and the osteoconductivity of methylcellulose-based injectable hydrogels. Int. J. Biol. Macromol. 2021, 192, 869-882. [CrossRef]

260. Blinova, A.A.; Blinov, A.V.; Baklanova, O.A.; Yasnaya, M.A.; Baklanov, I.S.; Siddiqui, A.A.; Golik, A.B.; Okolelova, A.I.; Gvozdenko, A.A.; Simonov, A.N.; et al. Study of Wound-Healing Ointment Composition based on Highly Dispersed Zinc Oxide Modified with Nanoscale Silver. Int. J. Pharm. Phytopharm. Res. 2021, 11, 134-142. [CrossRef]

261. Ghodrati Azadi, H.; Fathi, B.; Kazemi Mehrjerdi, H.; Maleki, M.; Shaterzadeh, H.; Abyazi, M.J. Macroscopic evaluation of wound healing activity of the Persian shallot, Allium hirtifolium in rat. Iran. J. Vet. Sci. Technol. 2011, 3, 31-38.

262. Volkova, N.; Yukhta, M.; Pavlovich, O.; Goltsev, A. Application of Cryopreserved Fibroblast Culture with Au Nanoparticles to Treat Burns. Nanoscale Res. Lett. 2016, 11, 22. [CrossRef] [PubMed]

263. Kim, M.H.; Park, H.; Shin, J.Y.; Park, W.H. Effect of vitamin derivatives on gelation rate and gel strength of methylcellulose. Carbohydr. Polym. 2018, 196, 414-421. [CrossRef] [PubMed]

264. Kim, M.H.; Park, H.; Nam, H.C.; Park, S.R.; Jung, J.Y.; Park, W.H. Injectable methylcellulose hydrogel containing silver oxide nanoparticles for burn wound healing. Carbohydr. Polym. 2018, 181, 579-586. [CrossRef] [PubMed]

265. Sriwiroch, W.; Chungsamarnyart, N.; Chantakru, S.; Pongket, P.; Saengprapaitip, K.; Pongchairerk, U.J.A.; Resources, N. The effect of Pedilanthus tithymaloides (L.) Poit crude extract on wound healing stimulation in mice. Agric. Nat. Resour. 2010, 44, 1121-1127.

266. Pislova, M.; Jackova, T.; Fajstavr, D.; Kolarova, K.; Svorcik, V. Release of Silver Nanoparticles from Polysaccharide Films Based on Methylcellulose; Tanger Ltd.: Slezska, Czech Republic, 2019; pp. 517-522.

267. Jung, H.S.; Kim, H.C.; Park, W.H. Robust methylcellulose hydrogels reinforced with chitin nanocrystals. Carbohydr. Polym. 2019, 213, 311-319. [CrossRef]

268. Denisova, E.V.; Suprunchuk, V.E.; Dronova, A.A. Biopolymeric materials containing brown algae polysaccharides. Entomol. Appl. Sci. Lett. 2017, 4, 19-23. [CrossRef] 
269. Das, B.; Basu, A.; Maji, S.; Dutta, K.; Dewan, M.; Adhikary, A.; Maiti, T.K.; Chattopadhyay, D. Nanotailored hyaluronic acid modified methylcellulose as an injectable scaffold with enhanced physico-rheological and biological aspects. Carbohydr. Polym. 2020, 237, 116146. [CrossRef]

270. Nowald, C.; Penk, A.; Chiu, H.Y.; Bein, T.; Huster, D.; Lieleg, O. A Selective Mucin/Methylcellulose Hybrid Gel with Tailored Mechanical Properties. Macromol. Biosci. 2016, 16, 567-579. [CrossRef]

271. Huang, Y.; Guo, W.; Zhang, J.; Peng, X.; Li, G.; Zhang, L.-M.; Yang, L. Thermosensitive hydrogels based on methylcellulose derivatives for prevention of postoperative adhesion. Cellulose 2019, 27, 1555-1571. [CrossRef]

272. Laffleur, F.; Strasdat, B. Gelatin-based formulations for dermal application. Eur. Polym. J. 2019, 118, 542-550. [CrossRef]

273. Yeo, Y.H.; Park, W.H. Dual-crosslinked, self-healing and thermo-responsive methylcellulose/chitosan oligomer copolymer hydrogels. Carbohydr. Polym. 2021, 258, 117705. [CrossRef] [PubMed]

274. Wang, C.Y.; Liang, C.Y.; Wang, R.; Yao, X.L.; Guo, P.; Yuan, W.Z.; Liu, Y.; Song, Y.; Li, Z.H.; Xie, X.Y. The fabrication of a highly efficient self-healing hydrogel from natural biopolymers loaded with exosomes for the synergistic promotion of severe wound healing. Biomater. Sci. 2020, 8, 313-324. [CrossRef]

275. Mayol, L.; De Stefano, D.; De Falco, F.; Carnuccio, R.; Maiuri, M.C.; De Rosa, G. Effect of hyaluronic acid on the thermogelation and biocompatibility of its blends with methyl cellulose. Carbohydr. Polym. 2014, 112, 480-485. [CrossRef]

276. Jiang, J.; Han, X.; Xu, H. Injectable Methylcellulose and Hyaluronic Acid Hydrogel Containing Silver Nanoparticles for Their Effective Anti-Microbial and Wound Healing Activity in Nursing Care for Burn Injuries in Children. J. Polym. Environ. 2021 under review. [CrossRef]

277. Kim, E.J.; Choi, J.S.; Kim, J.S.; Choi, Y.C.; Cho, Y.W. Injectable and Thermosensitive Soluble Extracellular Matrix and Methylcellulose Hydrogels for Stem Cell Delivery in Skin Wounds. Biomacromolecules 2016, 17, 4-11. [CrossRef]

278. Nagai, N.; Ogata, F.; Deguchi, S.; Ueno, A.; Kawasaki, N.; Ito, Y.J.B.; Bulletin, P. Combination ointment containing solid tranilast nanoparticles and dissolved sericin is efficacious for treating skin wound-healing deficits and redness in diabetic rats. Biol. Pharm. Bull. 2017, 40, 444-450. [CrossRef]

279. Park, C.H.; Jeong, L.; Cho, D.; Kwon, O.H.; Park, W.H. Effect of methylcellulose on the formation and drug release behavior of silk fibroin hydrogel. Carbohydr. Polym. 2013, 98, 1179-1185. [CrossRef]

280. Karavasili, C.; Tsongas, K.; Andreadis, I.I.; Andriotis, E.G.; Papachristou, E.T.; Papi, R.M.; Tzetzis, D.; Fatouros, D.G. Physicomechanical and finite element analysis evaluation of 3D printable alginate-methylcellulose inks for wound healing applications. Carbohydr. Polym. 2020, 247, 116666. [CrossRef]

281. Rastin, H.; Ramezanpour, M.; Hassan, K.; Mazinani, A.; Tung, T.T.; Vreugde, S.; Losic, D. 3D bioprinting of a cell-laden antibacterial polysaccharide hydrogel composite. Carbohydr. Polym. 2021, 264, 117989. [CrossRef]

282. Mishra, R.K.; Ramasamy, K.; Lim, S.M.; Ismail, M.F.; Majeed, A.B. Antimicrobial and in vitro wound healing properties of novel clay based bionanocomposite films. J. Mater. Sci. Mater. Med. 2014, 25, 1925-1939. [CrossRef] [PubMed]

283. Niziol, M.; Paleczny, J.; Junka, A.; Shavandi, A.; Dawiec-Lisniewska, A.; Podstawczyk, D. 3D Printing of Thermoresponsive Hydrogel Laden with an Antimicrobial Agent towards Wound Healing Applications. Bioengineering 2021, 8, 79. [CrossRef] [PubMed]

284. Lan, B.Y.; Zhang, L.M.; Yang, L.Q.; Wu, J.F.; Li, N.; Pan, C.L.; Wang, X.Y.; Zeng, L.X.; Yan, L.; Yang, C.; et al. Sustained delivery of MMP-9 siRNA via thermosensitive hydrogel accelerates diabetic wound healing. J. Nanobiotechnol. 2021, 19, 130. [CrossRef] [PubMed]

285. Gyles, D.A.; Pereira, A.D.; Castro, L.D.; Santa Brigida, A.; Lamarao, M.L.N.; Barbosa, W.L.R.; Silva, J.O.C.; Ribeiro-Costa, R.M. Polyacrylamide-Metilcellulose Hydrogels Containing Aloe barbadensis Extract as Dressing for Treatment of Chronic Cutaneous Skin Lesions. Polymers 2020, 12, 690. [CrossRef]

286. Schuhladen, K.; Raghu, S.N.V.; Liverani, L.; Nescakova, Z.; Boccaccini, A.R. Production of a novel poly(e-caprolactone)methylcellulose electrospun wound dressing by incorporating bioactive glass and Manuka honey. J. Biomed. Mater. Res. Part $B$ 2021, 109, 180-192. [CrossRef]

287. Zhang, H.Y.; Xie, Y.W.; Tang, Y.; Ni, S.H.; Wang, B.; Chen, Z.; Liu, X.J. Development and characterization of thermo-sensitive films containing asiaticoside based on polyvinyl alcohol and Methylcellulose. J. Drug Deliv. Sci. Technol. 2015, 30, 133-145. [CrossRef]

288. Yadav, B.K.N.; Patel, G.C. Fabrication and characterization of coblended methyl cellulose with polyvinyl alcohol electrospun nanofibers as a carrier for drug delivery system. Polym. Bull. 2021, 20, 1-29. [CrossRef]

289. Sun, N.; Wang, T.; Yan, X. Self-assembled supermolecular hydrogel based on hydroxyethyl cellulose: Formation, in vitro release and bacteriostasis application. Carbohydr. Polym. 2017, 172, 49-59. [CrossRef]

290. Lin, P.J.; Liu, L.L.; He, G.H.; Zhang, T.; Yang, M.; Cai, J.Z.; Fan, L.H.; Tao, S.X. Preparation and properties of carboxymethyl chitosan/oxidized hydroxyethyl cellulose hydrogel. Int. J. Biol. Macromol. 2020, 162, 1692-1698. [CrossRef]

291. Noreen, A.; Zia, K.M.; Tabasum, S.; Khalid, S.; Shareef, R. A review on grafting of hydroxyethylcellulose for versatile applications. Int. J. Biol. Macromol. 2020, 150, 289-303. [CrossRef]

292. Yamane, L.T.; de Paula, E.; Jorge, M.P.; de Freitas-Blanco, V.S.; Montanari, I.; Figueira, G.M.; Anholeto, L.A.; de Oliveira, P.R.; Rodrigues, R.A. Acmella oleracea and Achyrocline satureioides as Sources of Natural Products in Topical Wound Care. Evid.-Based Complement. Altern. Med. 2016, 2016, 3606820. [CrossRef] [PubMed]

293. Rosic, R.; Kocbek, P.; Baumgartner, S.; Kristl, J. Electro-spun hydroxyethyl cellulose nanofibers: The relationship between structure and process. J. Drug Deliv. Sci. Technol. 2011, 21, 229-236. [CrossRef] 
294. Raafat, A.I.; Ali, A.E.H. A novel Lawsonia inermis (Henna)/(hydroxyethylcellulose/polyvinylpyrrolidone) wound dressing hydrogel: Radiation synthesis, characterization and biological evaluation. Polym. Bull. 2019, 76, 4069-4086. [CrossRef]

295. Luo, P.F.; Liu, L.L.; Xu, W.Y.; Fan, L.H.; Nie, M. Preparation and characterization of aminated hyaluronic acid/oxidized hydroxyethyl cellulose hydrogel. Carbohydr. Polym. 2018, 199, 170-177. [CrossRef]

296. Ma, Y.L.; Zhou, G.; Ding, J.F.; Li, S.L.; Wang, G. Preparation and characterization of an agglomeration-cementing agent for dust suppression in open pit coal mining. Cellulose 2018, 25, 4011-4029. [CrossRef]

297. Ning, F.; Zhang, J.; Kang, M.X.; Ma, C.P.; Li, H.; Qiu, Z.M. Hydroxyethyl cellulose hydrogel modified with tannic acid as methylene blue adsorbent. J. Appl. Polym. Sci. 2021, 138, 49880. [CrossRef]

298. Kang, M.; Oderinde, O.; Han, X.; Fu, G.; Zhang, Z. Development of oxidized hydroxyethyl cellulose-based hydrogel enabling unique mechanical, transparent and photochromic properties for contact lenses. Int. J. Biol. Macromol. 2021, 183, 1162-1173. [CrossRef]

299. Zulkifli, F.H.; Shahitha, F.; Yusuff, M.M.; Hamidon, N.N.; Chahal, S. Cross-Linking Effect on Electrospun Hydroxyethyl Cellulose/Poly(Vinyl Alcohol) Nanofibrous Scaffolds. Procedia Eng. 2013, 53, 689-695. [CrossRef]

300. El Fawal, G.F.; Abu-Serie, M.M.; Hassan, M.A.; Elnouby, M.S. Hydroxyethyl cellulose hydrogel for wound dressing: Fabrication, characterization and in vitro evaluation. Int. J. Biol. Macromol. 2018, 111, 649-659. [CrossRef]

301. Taheri, H.; Hietala, M.; Oksman, K. One-step twin-screw extrusion process of cellulose fibers and hydroxyethyl cellulose to produce fibrillated cellulose biocomposite. Cellulose 2020, 27, 8105-8119. [CrossRef]

302. Fekete, T.; Borsa, J.; Takács, E.; Wojnárovits, L. Synthesis and characterization of superabsorbent hydrogels based on hydroxyethylcellulose and acrylic acid. Carbohydr. Polym. 2017, 166, 300-308. [CrossRef] [PubMed]

303. Zia, F.; Zia, K.M.; Aftab, W.; Tabasum, S.; Nazli, Z.-i.-H.; Mohammadi, M.; Zuber, M. Synthesis and characterization of graphene nanoplatelets-hydroxyethyl cellulose copolymer-based polyurethane bionanocomposite system. Int. J. Biol. Macromol. 2020, 165, 1889-1899. [CrossRef] [PubMed]

304. Zia, F.; Zia, K.M.; Nazli, Z.-i.-H.; Tabasum, S.; Khosa, M.K.; Zuber, M. Preparation of hydroxyethyl cellulose/halloysite nanotubes graft polylactic acid-based polyurethane bionanocomposites. Int. J. Biol. Macromol. 2020, 153, 591-599. [CrossRef]

305. Huang, S.; Shuyi, S.; Gan, H.; Linjun, W.; Lin, C.; Danyuan, X.; Zhou, H.; Lin, X.; Qin, Y. Facile fabrication and characterization of highly stretchable lignin-based hydroxyethyl cellulose self-healing hydrogel. Carbohydr. Polym. 2019, 223, 115080. [CrossRef]

306. Guo, M.; Yin, X.X.; Wang, P. C-13 NMR Characteristics and Thermal Properties of Hydroxyethyl Cellulose Grafting Poly(caprolactone) Copolymer. Asian J. Chem. 2013, 25, 4501-4505. [CrossRef]

307. Demina, T.S.; Birdibekova, A.V.; Svidchenko, E.A.; Ivanov, P.L.; Kuryanova, A.S.; Kurkin, T.S.; Khaibullin, Z.I.; Goncharuk, G.P.; Zharikova, T.M.; Bhuniya, S.; et al. Solid-State Synthesis of Water-Soluble Chitosan-g-Hydroxyethyl Cellulose Copolymers. Polymers 2020, 12, 611. [CrossRef]

308. Balaita, L.; Peptu, C.A.; Postolache, P.; Lisa, G.; Popa, M. Gelatin-hydroxyethyl cellulose magnetic microparticles as drug carriers: Preparation and characterization. J. Optoelectron. Adv. Mater. 2012, 14, 1023-1033.

309. Jamlang, J.; Marañon, M.T.; Rigor, G.J.; Tumolva, T. Developing a physically cross-linked hydroxyethyl cellulose hydrogel for wound dressing applications. In Materials Science Forum; Trans Tech Publications Ltd.: Kapellweg, Switzerland, 2019 ; pp. 3-12.

310. Arafa, A.A.; Nada, A.A.; Ibrahim, A.Y.; Zahran, M.K.; Hakeim, O.A. Greener therapeutic pH-sensing wound dressing based on Curcuma Longa and cellulose hydrogel. Eur. Polym. J. 2021, 159, 110744. [CrossRef]

311. Wang, C.W.; Niu, H.Y.; Ma, X.Y.; Hong, H.; Yuan, Y.; Liu, C.S. Bioinspired, Injectable, Quaternized Hydroxyethyl Cellulose Composite Hydrogel Coordinated by Mesocellular Silica Foam for Rapid, Noncompressible Hemostasis and Wound Healing. ACS Appl. Mater. Interfaces 2019, 11, 34595-34608. [CrossRef]

312. Zhang, Z.L.; Yang, R.D. Novel Nanocomposites Based on Hydroxyethyl Cellulose and Graphene Oxide. Fiber Polym. 2017, 18, 334-341. [CrossRef]

313. Zulkifli, F.H.; Hussain, F.S.J.; Zeyohannes, S.S.; Rasad, M.S.B.A.; Yusuff, M.M. A facile synthesis method of hydroxyethyl cellulose-silver nanoparticle scaffolds for skin tissue engineering applications. Mater. Sci. Eng. C 2017, 79, 151-160. [CrossRef] [PubMed]

314. Anumary, A.; Thanikaivelan, P.; Ashokkumar, M.; Kumar, R.; Sehgal, P.K.; Chandrasekaran, B. Synthesis and Characterization of Hybrid Biodegradable Films From Bovine Hide Collagen and Cellulose Derivatives for Biomedical Applications. Soft Mater. 2013, 11, 181-194. [CrossRef]

315. Zulkifli, F.H.; Jahir Hussain, F.S.; Abdull Rasad, M.S.B.; Mohd Yusoff, M. In vitro degradation study of novel HEC/PVA/collagen nanofibrous scaffold for skin tissue engineering applications. Polym. Degrad. Stab. 2014, 110, 473-481. [CrossRef]

316. Tohamy, K.M.; Soliman, I.E.; Mabrouk, M.; ElShebiney, S.; Beherei, H.H.; Aboelnasr, M.A.; Das, D.B. Novel polysaccharide hybrid scaffold loaded with hydroxyapatite: Fabrication, bioactivity, and in vivo study. Mater. Sci. Eng. C 2018, 93, 1-11. [CrossRef]

317. Kwon, S.S.; Kong, B.J.; Park, S.N. Physicochemical properties of pH-sensitive hydrogels based on hydroxyethyl cellulosehyaluronic acid and for applications as transdermal delivery systems for skin lesions. Eur. J. Pharm. Biopharm. 2015, 92, 146-154. [CrossRef] [PubMed]

318. Li, H.Y.; Zhang, Z.W.; Godakanda, V.U.; Chiu, Y.J.; Angkawinitwong, U.; Patel, K.; Stapleton, P.G.; de Silva, R.M.; de Silva, K.M.N.; Zhu, L.M.; et al. The effect of collection substrate on electrospun ciprofloxacin-loaded poly (vinylpyrrolidone) and ethyl cellulose nanofibers as potential wound dressing materials. Mater. Sci. Eng. C-Mater. Biol. Appl. 2019, 104, 109917. [CrossRef] 
319. Zhang, Y.; Sadgrove, M.P.; Mumper, R.J.; Jay, M. Transdermal Prodrug Delivery for Radionuclide Decorporation: Nonaqueous Gel Formulation Development and In Vitro and In Vivo Assessment. Drug Dev. Res. 2013, 74, 322-331. [CrossRef]

320. Lin, Y.M.; Li, M.; Xia, J.L.; Ding, H.Y.; Xu, L.N.; Yang, X.H.; Li, S.H. Synthesis of plant oil derived polyols and their effects on the properties of prepared ethyl cellulose composite films. Cellulose 2021, 28, 4211-4222. [CrossRef]

321. Ghorbani, M.; Ramezani, S.; Rashidi, M.R. Fabrication of honey-loaded ethylcellulose/gum tragacanth nanofibers as an effective antibacterial wound dressing. Colloid Surf. A-Physicochem. Eng. Asp. 2021, 621, 126615. [CrossRef]

322. Xu, J.Y.; Jia, H.G.; Yang, N.; Wang, Q.J.; Yang, G.X.; Zhang, M.Y.; Xu, S.P.; Zang, Y.; Ma, L.Q.; Jiang, P.F.; et al. High Efficiency Gas Permeability Membranes from Ethyl Cellulose Grafted with Ionic Liquids. Polymers 2019, 11, 1900. [CrossRef] [PubMed]

323. Mahnaj, T.; Ahmed, S.U.; Plakogiannis, F.M. Characterization of ethyl cellulose polymer. Pharm. Dev. Technol. 2013, 18, 982-989. [CrossRef] [PubMed]

324. Zhao, X.Y.; Yan, G.H.; Sun, Y.; Tang, X.; Zeng, X.H.; Lin, L.; Lei, T.Z. Preparation of Ethyl Cellulose Composite Film with Down Conversion Luminescence Properties by Doping Perovskite Quantum Dots. ChemistrySelect 2019, 4, 6516-6523. [CrossRef]

325. Djerafi, R.; Masmoudi, Y.; Crampon, C.; Meniai, A.; Badens, E. Supercritical anti-solvent precipitation of ethyl cellulose. J. Supercrit. Fluids 2015, 105, 92-98. [CrossRef]

326. Suksaeree, J.; Thuengernthong, A.; Pongpichayasiri, K.; Maneewattanapinyo, P.; Settharaksa, S.; Pichayakorn, W. Formulation and Evaluation of Matrix Type Transdermal Patch Containing Silver Nanoparticles. J. Polym. Environ. 2018, 26, 4369-4375. [CrossRef]

327. Su, X.C.; Yang, Z.; Tan, K.B.; Chen, J.F.; Huang, J.L.; Li, Q.B. Preparation and characterization of ethyl cellulose film modified with capsaicin. Carbohydr. Polym. 2020, 241, 116259. [CrossRef]

328. Li, H.Y.; Liu, K.L.; Sang, Q.Q.; Williams, G.R.; Wu, J.Z.; Wang, H.J.; Wu, J.R.; Zhu, L.M. A thermosensitive drug delivery system prepared by blend electrospinning. Colloid Surf. B Biointerfaces 2017, 159, 277-283. [CrossRef]

329. Girija, B.G.; Sailaja, R.R.N.; Biswas, S.; Deepthi, M.V. Mechanical and Thermal Properties of Eva Blended with Biodegradable Ethyl Cellulose. J. Appl. Polym. Sci. 2010, 116, 1044-1056. [CrossRef]

330. Chen, J.X.; Wu, D.F.; Pan, K.R. Effects of ethyl cellulose on the crystallization and mechanical properties of poly(betahydroxybutyrate). Int. J. Biol. Macromol. 2016, 88, 120-129. [CrossRef]

331. Li, X.; Jiang, F.T.; Ni, X.W.; Yan, W.L.; Fang, Y.P.; Corke, H.; Xiao, M. Preparation and characterization of konjac glucomannan and ethyl cellulose blend films. Food Hydrocoll. 2015, 44, 229-236. [CrossRef]

332. Borujeni, S.H.; Mirdamadian, S.Z.; Varshosaz, J.; Taheri, A. Three-dimensional (3D) printed tablets using ethyl cellulose and hydroxypropyl cellulose to achieve zero order sustained release profile. Cellulose 2020, 27, 1573-1589. [CrossRef]

333. Godakanda, V.U.; Li, H.Y.; Alquezar, L.; Zhao, L.X.; Zhu, L.M.; de Silva, R.; de Silva, K.M.N.; Williams, G.R. Tunable drug release from blend poly(vinyl pyrrolidone)-ethyl cellulose nanofibers. Int. J. Pharm. 2019, 562, 172-179. [CrossRef] [PubMed]

334. Yang, J.K.; Wang, K.; Yu, D.G.; Yang, Y.Y.; Bligh, S.W.A.; Williams, G.R. Electrospun Janus nanofibers loaded with a drug and inorganic nanoparticles as an effective antibacterial wound dressing. Mater. Sci. Eng. C Mater. Biol. Appl. 2020, $111,110805$. [CrossRef] [PubMed]

335. Iqbal, H.M.N.; Kyazze, G.; Locke, I.C.; Tron, T.; Keshavarz, T. Poly(3-hydroxybutyrate)-ethyl cellulose based bio-composites with novel characteristics for infection free wound healing application. Int. J. Biol. Macromol. 2015, 81, 552-559. [CrossRef]

336. Ahmadian, S.; Ghorbani, M.; Mahmoodzadeh, F. Silver sulfadiazine-loaded electrospun ethyl cellulose/polylactic acid/collagen nanofibrous mats with antibacterial properties for wound healing. Int. J. Biol. Macromol. 2020, 162, 1555-1565. [CrossRef] [PubMed]

337. Qiu, Y.; Wang, Q.Q.; Chen, Y.J.; Xia, S.F.; Huang, W.; Wei, Q.F. A Novel Multilayer Composite Membrane for Wound Healing in Mice Skin Defect Model. Polymers 2020, 12, 573. [CrossRef]

338. Kapileshwari, G.R.; Barve, A.R.; Kumar, L.; Bhide, P.J.; Joshi, M.; Shirodkar, R.K. Novel drug delivery system of luliconazoleFormulation and characterisation. J. Drug Deliv. Sci. Technol. 2020, 55, 101302. [CrossRef]

339. Ogawa, A.; Nakayama, S.; Uehara, M.; Mori, Y.; Takahashi, M.; Aiba, T.; Kurosaki, Y. Pharmaceutical properties of a lowsubstituted hydroxypropyl cellulose (L-HPC) hydrogel as a novel external dressing. Int. J. Pharm. 2014, 477, 546-552. [CrossRef]

340. Bhatt, N.; Gupta, P.M.; Naithani, S. Hydroxypropyl cellulose from alpha-cellulose isolated from Lantana camara with respect to DS and rheological behavior. Carbohydr. Polym. 2011, 86, 1519-1524. [CrossRef]

341. Lin, C.M.; Chang, Y.C.; Cheng, L.C.; Liu, C.H.; Chang, S.C.; Hsien, T.Y.; Wang, D.M.; Hsieh, H.J. Preparation of grapheneembedded hydroxypropyl cellulose/chitosan/polyethylene oxide nanofiber membranes as wound dressings with enhanced antibacterial properties. Cellulose 2020, 27, 2651-2667. [CrossRef]

342. Miao, L.; Hu, J.W.; Lu, M.G.; Tu, Y.Y.; Chen, X.; Li, Y.W.; Lin, S.D.; Li, F.; Hu, S.Y. Alkynyl-functionalization of hydroxypropyl cellulose and thermoresponsive hydrogel thereof prepared with P(NIPAAm-co-HEMAPCL). Carbohydr. Polym. 2016, 137, 433-440. [CrossRef]

343. Szabo, P.; Kallai-Szabo, B.; Kallai-Szabo, N.; Sebe, I.; Zelko, R. Preparation of hydroxypropyl cellulose microfibers by high-speed rotary spinning and prediction of the fiber-forming properties of hydroxypropyl cellulose gels by texture analysis. Cellulose 2014, 21, 4419-4427. [CrossRef]

344. Ishii, D.; Ueda, K.; Stroeve, P.; Nakaoki, T.; Hayashi, H. Transport properties of chemically crosslinked hydroxypropyl cellulose in solvated state. Cell Chem. Technol. 2016, 50, 755-760.

345. Ma, L.; Wang, L.L.; Wu, L.X.; Zhuo, D.X.; Weng, Z.X.; Ren, R.R. Cellulosic nanocomposite membranes from hydroxypropyl cellulose reinforced by cellulose nanocrystals. Cellulose 2014, 21, 4443-4454. [CrossRef] 
346. El-Newehy, M.H.; El-Naggar, M.E.; Alotaiby, S.; El-Hamshary, H.; Moydeen, M.; Al-Deyab, S. Green Electrospining of Hydroxypropyl Cellulose Nanofibres for Drug Delivery Applications. J. Nanosci. Nanotechnol. 2018, 18, 805-814. [CrossRef]

347. Saraiva, D.V.; Chagas, R.; de Abreu, B.M.; Gouveia, C.N.; Silva, P.E.S.; Godinho, M.H.; Fernandes, S.N. Flexible and Structural Coloured Composite Films from Cellulose Nanocrystals/Hydroxypropyl Cellulose Lyotropic Suspensions. Crystals 2020, 10, 122. [CrossRef]

348. Bielska, D.; Karewicz, A.; Kaminski, K.; Kielkowicz, I.; Lachowicz, T.; Szczubialka, K.; Nowakowska, M. Self-organized thermoresponsive hydroxypropyl cellulose nanoparticles for curcumin delivery. Eur. Polym. J. 2013, 49, 2485-2494. [CrossRef]

349. El-Wakil, N.A.; Kassem, N.F.; Hassan, M.L. Hydroxypropyl cellulose/rice straw oxidized cellulose nanocrystals nanocomposites and their use in paper coating. Ind. Crop. Prod. 2016, 93, 186-192. [CrossRef]

350. Sudo, S. Dielectric Properties of the Free Water in Hydroxypropyl Cellulose. J. Phys. Chem. B 2011, 115, 2-6. [CrossRef] [PubMed]

351. Veerapur, R.S.; Gudasi, K.B.; Aminabhavi, T.M. Pervaporation dehydration of isopropanol using blend membranes of chitosan and hydroxypropyl cellulose. J. Membr. Sci. 2007, 304, 102-111. [CrossRef]

352. Onofrei, M.D.; Dobos, A.M.; Stoica, I.; Olaru, N.; Olaru, L.; Ioan, S. Lyotropic Liquid Crystal Phases in Cellulose Acetate Phthalate/Hydroxypropyl Cellulose Blends. J. Polym. Environ. 2014, 22, 99-111. [CrossRef]

353. Gan, S.C.; Bai, S.H.; Chen, C.; Zou, Y.L.; Sun, Y.J.; Zhao, J.H.; Rong, J.H. Hydroxypropyl cellulose enhanced ionic conductive double-network hydrogels. Int. J. Biol. Macromol. 2021, 181, 418-425. [CrossRef] [PubMed]

354. Lu, C.W.; Wang, C.P.; Zhang, D.H.; Wang, J.F.; Yong, Q.; Chu, F.X. Ultra-strong hydroxypropyl cellulose/polyvinyl alcohol composite hydrogel by combination of triple-network and mechanical training. Int. J. Biol. Macromol. 2021, 184, 200-208. [CrossRef] [PubMed]

355. Bjorn, C.; Noppa, L.; Salomonsson, E.N.; Johansson, A.L.; Nilsson, E.; Mahlapuu, M.; Hakansson, J. Efficacy and safety profile of the novel antimicrobial peptide PXL150 in a mouse model of infected burn wounds. Int. J. Antimicrob. Agents 2015, 45, 519-524. [CrossRef] [PubMed]

356. Wang, Y.W.; Shi, L.J.; Wu, H.P.; Li, Q.Y.; Hu, W.; Zhang, Z.B.; Huang, L.H.; Zhang, J.X.; Chen, D.J.; Deng, S.P.; et al. Graphene Oxide-IPDI-Ag/ZnO@Hydroxypropyl Cellulose Nanocomposite Films for Biological Wound-Dressing Applications. ACS Omega 2019, 4, 15373-15381. [CrossRef]

357. Wang, J.J.; Wei, J. Interpenetrating network hydrogels with high strength and transparency for potential use as external dressings. Mater. Sci. Eng. C Mater. Biol. Appl. 2017, 80, 460-467. [CrossRef]

358. Rojewska, A.; Karewicz, A.; Karnas, K.; Wolski, K.; Zajac, M.; Kaminski, K.; Szczubialka, K.; Zapotoczny, S.; Nowakowska, M. Pioglitazone-Loaded Nanostructured Hybrid Material for Skin Ulcer Treatment. Materials 2020, 13, 2050. [CrossRef]

359. Tolouei, S.; Hasheminia, S.J.; Narimani, M.; Khamesipour, A.; Shatalebi, M.A.; Hejazi, S.H. Leishmanicidal Activity of Films Containing Paromomycin and Gentamicin Sulfate both In Vitro and In Vivo. Iran. J. Parasitol. 2011, 6, 60-65.

360. Mohebian, Z.; Tajmohammadi, I.; Maroufi, L.Y.; Ramezani, S.; Ghorbani, M. A Novel Aloe Vera-Loaded Ethylcellulose/Hydroxypropyl Methylcellulose Nanofibrous Mat Designed for Wound Healing Application. J. Polym. Environ. $2021,11$. [CrossRef]

361. Koneru, A.; Dharmalingam, K.; Anandalakshmi, R. Cellulose based nanocomposite hydrogel films consisting of sodium carboxymethylcellulose-grapefruit seed extract nanoparticles for potential wound healing applications. Int. J. Biol. Macromol. 2020, 148, 833-842. [CrossRef]

362. Dharmalingam, K.; Bordoloi, D.; Kunnumakkara, A.B.; Anandalakshmi, R. Preparation and characterization of cellulose-based nanocomposite hydrogel films containing $\mathrm{CuO} / \mathrm{Cu} 2 \mathrm{O} / \mathrm{Cu}$ with antibacterial activity. J. Appl. Polym. Sci. 2020, 137, 49216. [CrossRef]

363. Dharmalingam, K.; Anandalakshmi, R. Fabrication, characterization and drug loading efficiency of citric acid crosslinked NaCMCHPMC hydrogel films for wound healing drug delivery applications. Int. J. Biol. Macromol. 2019, 134, 815-829. [CrossRef] [PubMed]

364. Dharmalingam, K.; Bordoloi, D.; Kunnumakkara, A.B.; Anandalakshmi, R. Formation and characterization of zinc oxide complexes in composite hydrogel films for potential wound healing applications. Polym. Compos. 2020, 41, 2274-2287. [CrossRef]

365. Amanat, S.; Taymouri, S.; Varshosaz, J.; Minaiyan, M.; Talebi, A. Carboxymethyl cellulose-based wafer enriched with resveratrolloaded nanoparticles for enhanced wound healing. Drug Deliv. Transl. Res. 2020, 10, 1241-1254. [CrossRef]

366. Rezvanian, M.; Tan, C.K.; Ng, S.F. Simvastatin-loaded lyophilized wafers as a potential dressing for chronic wounds. Drug Dev. Ind. Pharm. 2016, 42, 2055-2062. [CrossRef] [PubMed] 